\title{
MLAM Assessment of Air Concentration, Deposition, and Dose for Chernobyl Reactor Accident
}
A. R. Olsen
J. K. Soldat
W. E. Davis
B. A. Napier
B. T. Didier
R. A. Peloquin

December 1989

Prepared for the U.S. Department of Energy under Contract DE-ACO6-76RLO 1830

Pacific Northwest Laboratory

Operated for the U.S. Department of Energy

by Battelle Memorial Institute 


\title{
DISCLAIMER
}

This program was prepared as an account of work sponsored by an agency of the United States Government. Neither the United States Government nor any agency thereof, nor Battelle Memorial Institute, nor any of their employees, makes any warranty, express or implled, or assumes any legal liability or responsibility for the accuracy, completeness, or usefulness of any information, apparatus, product, or process disclosed, or represents that its use would not infinge privateły owned rights. Reference herein to any specific commerical product, process, or service by trade name, trademark, manufacturer, or otherwise, does not necessarily constitute or imply its endorsement, recommendation, or favoring by the United States Government or any agency thereof, or Battelle Memorial Institute. The views and opinions of authors expressed herein do not necessarily state or reflect those of the United States Government or any agency thereof.

\section{PACIFIC NORTHWEST LABORATORY operated by \\ BATTELLE MEMORIAL INSTITUTE \\ for the \\ UNITED STATES DEPARTMENT OF ENERGY \\ under Contract DE-ACO6-76RLO 1830}

\author{
Printed in the United States of America \\ Available from \\ National Technical Information Service \\ United States Department of Commerce \\ 5285 Port Royal Road \\ Springfield, Virginia 22361 \\ NTIS Price Codes \\ Microfiche A01 \\ Printed Copy
}

$\begin{array}{cc}\text { Pages } & \begin{array}{c}\text { Price } \\ \text { Codes }\end{array} \\ 001-025 & \text { A02 } \\ 026-050 & \text { A03 } \\ 051-075 & \text { AO4 } \\ 076-100 & \text { A05 } \\ 101-125 & \text { A06 } \\ 126-150 & \text { A07 } \\ 151-175 & \text { A08 } \\ 176-200 & \text { A09 } \\ 201-225 & \text { A10 } \\ 226-250 & \text { A11 } \\ 251-275 & \text { A12 } \\ 276-300 & \text { A13 }\end{array}$


MLAM ASSESSMENT OF AIR CONCENTRATION, DEPOSITION, AND DOSE FOR CHERNOBYL REACTOR ACCIDENT
A. R. 01sen
W. E. Davis
B. T. Didier
J. K. Soldat
B. A. Napier
R. A. Peloquin

December 1989

Prepared for

the U.S. Department of Energy

under Contract DE-ACO6-76RLO 1830

Pacific Northwest Laboratory

Richland, Washington 99352 


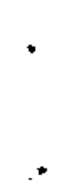




\section{$\underline{\text { SUMMARY }}$}

Shortly after midnight local time on April 26, 1986, an accident involving Unit 4 of the Chernobylskaya Atomic Energy Station resulted in the release of radioactive material to the atmosphere, which continued through May 5, 1986. The spatial and temporal patterns of air concentrations and depositions that resulted are predicted for Europe by a multi-layer, three-dimensional, mesoalpha scale atmospheric transport model. MLAM. Information is provided on the atmospheric transport of the effluent plume from the damaged reactor, surface air concentrations, wet and dry deposition to the ground, and the resultant radiation doses from the deposited radionuclides. Numerous measurements were made after the accident, and in some countries the observations may be sufficient to determine general air concentration and deposition patterns. However, there are large areas in Europe where such measurements are not available, and it is in these areas that modeling provides additional aid in determining the impact of the accident. The purpose of this report is to provide estimates for these areas.

Comparison of the calculated air concentrations and deposition with available measured data indicated that the patterns from the calculated values generally reproduced the patterns from the measured data. Wet deposition basec on 24-h precipitation data appeared to be underestimated in regions where significant precipitation occurred. Spatial patterns determined from modeled deposition for cesium-137 and jodine-131 provided information on the extent of the Chernobyl reactor accident's impact. Of the $806 \mathrm{kCi}$ of cesium-137 and 16.4 MCi of jodine-131 assumed to be released between Apri 26 and May 5, $60 \%$ was estimated to be deposited within western and eastern Europe. Approximately $70 \%$ of the total deposition of cesium-137 and $50 \%$ of the total deposition of iodine-131 occurred as wet deposition.

On May 15, 1986, the regional impact of total (wet and dry) deposition of cesium-137 was calculated to be greater than $100 \mathrm{~Bq} / \mathrm{m}^{2}\left(2700 \mathrm{pCi} / \mathrm{m}^{2}\right)$ for all of Europe east of central France, extending to the Mediterranean Sea and Turkey to the south and nortbern Scandinavia and the USSR to the north. The same region was also calculated to have greater than $100 \mathrm{~Bq} / \mathrm{m}^{2}$ for total deposition of iodine-131. The maximum calculated deposition of cesium-137 
was approximately $50,000 \mathrm{~Bq} / \mathrm{m}^{2}$, immediately northwest of Chernobyl. Total deposition of cesium-137 greater than $1,000 \mathrm{~Bq} / \mathrm{m}^{2}$ extended from central Finland to southern Turkey and from Czechoslovakia to east of Moscow, with local peaks of over $15,000 \mathrm{~Bq} / \mathrm{m}^{2}$ southeast of Moscow. Near the Ob River, a local maximum of $35,000 \mathrm{~Bq} / \mathrm{m}^{2}$ for iodine-131 was calculated to occur. Total deposition of iodine-131 greater than $100,000 \mathrm{~Bq} / \mathrm{m}^{2}$ was calculated to occur immediately northwest of Chernobyl and along the initial transport path between Minsk and the eastern border of Poland. The maximum calculated deposition of iodine-131 was approximately $650,000 \mathrm{~Bq} / \mathrm{m}^{2}$ immediately northwest of Chernobyl.

Surface deposition calculated by MLAM was used in the PABLM model to calculate lifetime (70-year) radiation doses to individuals and population groups. The model calculates accumulated doses from chronic ingestion of contaminated food products and from external exposure to radionuclides in the environment. The maximum estimated lifetime radiation dose category assuming a 70-year exposure period, is 10 to $100 \mathrm{mSv}$ ( 1 to $10 \mathrm{rem}$ ). This category encloses a three-pronged region that extended northwest toward Finland, south to the Black Sea, and northeast toward Moscow from Chernobyl. Dose estimates for western Europe were less than $0.10 \mathrm{mSv}$ (10 mrem). Most of eastern Europe and the north-central USSR had estimated doses greater than $0.10 \mathrm{mSv}$, with the eastern portion generally exceeding $1.0 \mathrm{mSv}$. The calculated lifetime collective radiation dose for Europe was 540,000 person-Sv (excluding dose from inhalation and ingestion of initially contaminated food). For the portion of the USSR included in the study area, the total collective dose was 340,000 person-Sv. This collective dose translates to an average per-person dose of $3.1 \mathrm{mSv}(0.31 \mathrm{rem})$. Within the USSR, the calculated collective radiation dose for the Ukraine was 260,000 person-Sv (5.2 mSv average per person dose) and for Byelorussia was 16,000 person-Sv (1.7 mSv average per person dose). 


\section{ACKNOWLEDGMENTS}

The support, advice, and encouragement of our co-workers have made our work possible on the assessment of the impact of the Chernobyl reactor accident. Jim Davidson and Dick Kleinknecht provided initial direction and administrative encouragement. Van Ramsdell coordinated his study of dose within $80 \mathrm{~km}$ of the reactor with our efforts and aided in the characterization of the source term for radionuclide release. Winston Little of Pacific Northwest Laboratory provided needed expertise for defining the final core inventory estimates used. Trudy Erb, Paul Tucker, and Dennis Damschen provided essential computational support. Our discussions with other researchers studying the effluent transport and resultant deposition and dose associated with the accident have led to clarifications in our approach. 



\section{CONTENTS}

SUMMARY

ACKNOWLEDGMENTS

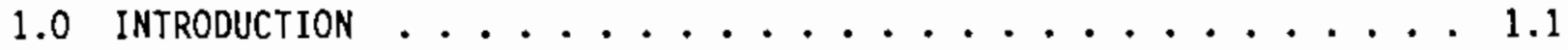

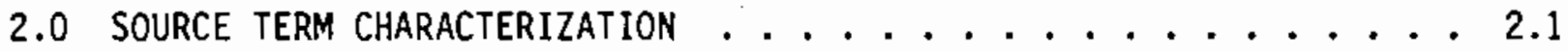

3.0 METEOROLOGICAL CONDITIONS AND DATA PREPARATION $\ldots \ldots \ldots . . \ldots$

4.0 MLAM MODEL ASSUMPTIONS . . . . . . . . . . . . 4.1

5.0 LIFETIME RADIATION DOSES . . . . . . . . . . . 5.1

5.1 PABLM RADIATION DOSE MODEL . . . . . . . . . . 5.1

5.1 .1 Radiation Doses to Individuals ........ 5.2

5.1 .2 Collective Radiation Doses ............. 5.3

5.2 LIFETIME RADIATION DOSE RESULTS . . . . . . . . 5.3

5.2 .1 Radiation Doses to Individuals ........ 5.4

5.2.2 Population Dose By Country . . . . . . . . 5.7

6.0 MODELED DEPOSITION FOR WESTERN AND EASTERN EUROPE $\ldots \ldots \ldots . . \ldots$

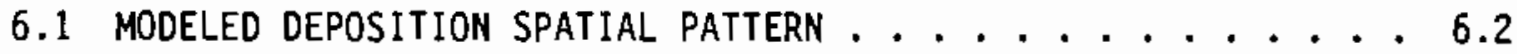

6.1.1 Cumulative Deposition From April 26 to May $15 \ldots 6.4$

6.1.2 Cesium-137 Separated by Release Period . . . . . 6.12

6.1.3 Cumulative Deposition for Intermediate Dates of May 1 and May 5............. 6.18

6.2 DEPOSITION TEMPORAL PATTERN AT SELECTED LOCATIONS $\ldots . . . \quad 6.27$

7.0 estimated SURface Air CONCENTRATIONS . . . . . . . . . 7.1

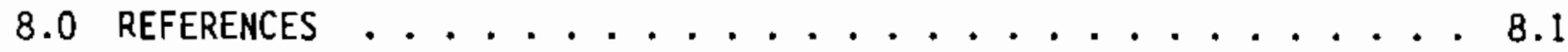




\section{FIGURES}

3.1 Kiev Sounding for 002 April 26, 1986 . . . . . . . . . 3.2

3.2 Surface fronts over Europe for 002 April 28, $1986 \ldots . . \ldots .2$

3.3 Surface Fronts over Europe for 002 April 30, $1986 \ldots 3 . . . . . .3$

3.4 Surface Fronts over Europe for 002 May 2, $1986 \ldots 3.3$

4.1 Out Tine of Fine-Mesh Deposition Grid . . . . . . . . . 4.2

5.1 Lifetime Radiation Doses to Individuals frem $70-\mathrm{yr}$

Exposure to Residual Contamination on the Ground and

in Food (mSv), (a) Europe and (b) Eastern Europe . . . . . . 5.5

5.2 Lifetime Radiation Doses to Individuals from $1-\mathrm{yr}$

Exposure to Residual Contamination on the Ground and

in Food (mSv), (a) Europe and (b) Eastern Europe . . . . . . 5.6

6.1 Polar Stereographic Projection Maps for (a) Europe

and (b) Eastern Europe .................. 6.3

6.2 Cesium-137 Total Deposition, Cumulative to May 15, 1986,

Spatial Pattern for (a) Europe and (b) Eastern Europe . . . . . 6.5

6.3 Cesium-137 Wet $(a, b)$ and Dry $(c, d)$ Deposition,

Cumulative to May 15, 1986, Spatial Patterns

for Europe and Eastern Europe . . . . . . . . . . . 6.7

6.4 Cesium-137 Deposition Spatial Pattern in Scandinavia

Based on Available Measured Data .............. 6.8

6.5 Iodine-131 Total Deposition, Cumulative to May 15, 1986,

Spatial Pattern for (a) Europe and (b) Eastern Europe . . . . . 6.9

6.6 Iodine-13I Wet $(a, b)$ and Dry $(c, d)$ Deposition,

Cumulative to May 15, 1986, Spatial Patterns

for Europe and Eastern Europe . . . . . . . . . . . 6.11

6.7 Cesium-137 Total Deposition, Cumulative to May 15, 1986,

Spatial Pattern from Initial Release at 002 on April 26,

1986, for (a) Europe and (b) Eastern Europe . . . . . . . . . 6.14

6.8 Cesium-137 Total Deposition, Cumulative to May 15, 1986, Spatial Pattern from April 26 To April 30 Release for

(a) Europe and (b) Eastern Europe ............. 6. 6.16

6.9 Cesium-137 Total Deposition, Cumulative to May 15, 1986, Spatial Pattern from May 1 To May 5 Release for (a) Europe and (b) Eastern Europe 
6.10 Cesium-137 Total Deposition, Cumulative to May 1, 1986 , Spatial Pattern for (a) Europe and (b) Eastern Europe . . . . . 6.19

6.11 Iodine-131 Total Deposition, Cumulative to May 1, 1986, Spatial Pattern for (a) Europe and (b) Eastern Europe . . . . 6.20

6.12 Cesium-137 Wet $(a, b)$ and Dry $(c, d)$ Deposition, Cumulative to May 1, 1986. Spatial Patterns for Europe and Eastern Europe . . . . . . . . . . . 6.21

6.13 Iodine-131 Wet $(a, b)$ and Dry (c,d) Deposition, Cumulative to May 1, 1986, Spatial Patterns for Europe and Eastern Europe . . . . . . . . . . 6.22

6.14 Cesium-137 Total Deposition, Cumulative to May 5, 1986, Spatial Pattern for (a) Europe and (b) Eastern Europe . . . . 6.23

6.15 Iodine-131 Total Deposition, Cumulative to May 5, 1986, Spatial Pattern for (a) Europe and (b) Eastern Europe . . . . 6.24

6.16 Cesium-137 Wet $(a, b)$ and Dry (c,d) Deposition, Cumulative to May 5, 1986, Spatial Patterns for Europe and Eastern Europe . . . . . . . . . . 6.25

6.17 Iodine-131 Wet $(a, b)$ and Dry $(c, d)$ Deposition, Cumulative to May 5, 1986, Spatial Patterns for Europe and Eastern Europe . . . . . . . . . 6.26

6.18 Cesium-137 Daily Deposition at Helsinki, Risp, Bilthoven, Budapest, and Varese ........... 6.28

6.19 Cesium-137 Daily Deposition at Ankara, Vierna, Bucharest, and Moscow .............. 6.32

7.1 Xenon-133 Daily Air Concentration Spatial Pattern for April 26 to May 13,1986 ............... 7.2

7.2 Cesium-137 Daily Air Concentrations at Helsinki, Riso, Bilthoven, Budapest, and Varese ......... 7.5

7.3 Iodine-131 Daily Air Concentrations at Helsinki, Riso, Bilthoven, Budapest, and Varese ......... 7.6 


\section{TABLES}

2.1 Radionuclide Source Term Characterization Used in MLAM Modeling . . . . . . . . . . . . . 2.2

4.1 Deposition Velocities and Washout Coefficients for Radionuclide Deposition ............. 4.3

5.1 Estimated Lifetime (70-yr) Population Doses from Total (Dry and Wet) Deposition of Radionuclides in Europe Fol lowing the 1986 Chernobyl Accident ......... 5.8

6.1 Quantity of Cesium-137 and Iodine-131 Released and Deposited for Three Release Periods. . . . . . . . . . . . 6.12

6.2 Observed and Modeled (Wet and Total) Deposition for Selected Cities ............... 6.29

7.1 Comparison of Measured and Modeled Air Concentrations . . . . 7.7 


\subsection{INTRODUCTION}

Shortly after midnight local time on April 26, 1986, an accident involving Unit 4 of the Chernobylskaya Atomic Energy Station resulted in the release of radioactive material to the atmosphere. The events leading to the accident are described in other documents (USSR 1986. IAEA 1986). Briefly, power was being reduced on the 3200-MWt reactor, which had been in operation since December 1983, in preparation for a maintenance shutdown. While the reactor was at low power, an experiment was performed that resulted in one or more prompt critical excursions at 1:23 a.m. local time on April 26, 1986 (23232 on April 25). These excursions led to an explosion, which destroyed the reactor, and fires that resulted in a protracted release of radioactive material to the atmosphere. Starting on April 28, helicopters dropped materials on the reactor to control the release of radioactive effluent. By May 5, 1986, the accident release was essentially over.

After the accident, numerous investigators began to monitor air concentrations and wet deposition of the radioactive effluent and to model the transport path of the effluent to gain information on the possible environmental and health consequences of the accident. One example of the initial response is given by Davis et al. (1989), who modeled the surface footprint from the initial release using a meso-alpha scale model MLAM. A great deal of scientific attention has since been focussed on the consequences of the release. Major areas of interest are estimation of the health effects of the release based on radiation measurements and modeling of the transport, diffusion, and deposition of the effluent on local, continental, and global scales. Ramsdell et al. (1989) completed an assessment of the doses near the reactor (within $80 \mathrm{~km}$ ) using the MESORAD dose assessment model. Other meteorological studies have been completed by ApSimon and Wilson (1986) using the MESOS model and de Leeliw, Van Aalst, and Van Dop (1987) using the GRID model.

This report describes an analys is of the spatial and temporal patterns of ain concentrations and depositions predicted for western and eastern Europe by a multi-layer, three-dimensional, meso-alpha scale model, MLAM. Information is provided on the atmospheric transport of the effluent plume from the damaged reactor, concentrations in the air, wet and dry deposition to the ground, and 
the resultant radiation doses from the deposited radionuclides. Numerous measurements were made after the accident, and in some countries the observations may be sufficient to determine general air concentration and deposition patterns. However, there are large areas in Europe where such measurements are not available, and it is in these areas that modeling provides additional aid in determining the impact of the accident.

The MLAM model, developed at the Pacific Northwest Laboratory (Davis et al. 1986), provides three-dimensional transport, diffusion, and deposition (wet and dry) of source effluent at the meso-alpha (100 to $1000 \mathrm{~km}$ ) to synoptic scale. MLAM has been modified for application to Chernobyl through the addition of dry and wet deposition algorithms capable of estimating daily deposition on a fine-mesh deposition grid (0.1 NMC grid density). Provision is made to handle transport, diffusion, deposition, and decay corrections for multiple radionuclides. Information generated includes trajectory paths, spatial patterns of air concentrations and deposition (dry, wet and total), and temporal patterns for specific locations.

The PABLM model, developed by the Pacific Northwest Laboratory (Napier, Kennedy and Soldat 1980), was used to calculate lifetime (70-year) radiation doses to individuals and population groups. The model is designed to calculate accumulated doses from chronic ingestion of contaminated food products and from external exposure to radionuclides in the environment. The radiation dosimetry is based on the model defined in Publication 2 of the International Commission on Radiological Protection (ICRP 1959).

This report is organized as follows. Section 2 describes the source term characterization for the releases from the Chernobyl accident assumed as input to MLAM. Meteorological conditions in Europe at the time of the accident and meteorological data preparation required for transport and wet deposition are described in Section 3. A brief, but comprehensive, overview of key MLAM model features and algorithms is given in Section 4. Calculated potential radiation doses are discussed in Section 5. In Section 6, spatial and temporal deposition patterns calculated by the MLAM model are presented and, where possible, compared to measured wet and total deposition values. Finally, spatial and temporal patterns of the calculated air concentrations are discussed in Section 7 . 


\subsection{SOURCE TERM CHARACTERIZATION}

Characterization of the radionuclide releases from the Chernobyl accident depends on specifying the reactor core inventory at the time of the accident and the amount released over time. Proper modeling of subsequent transport of the material also requires information on the release height, which may vary with time. This section describes assumptions used in this source term characterization. All air concentration, deposition, and dose calculations reported are based on these assumptions.

An inventory of radionuclides in the core of the Chernobyl Unit 4 reactor and available for release at the time of the accident was estimated. This estimate formed the basis for the rest of the source term characterization. The core inventory was estimated by an ORIGIN (Croff 1980) computer code simulation of an RBMK reactor (Goldman et a1, 1987). The ORIGIN inventory estimate is consistent with a Soviet estimate of the core inventory (USSR 1986). The activity is given as that present at the time of the accident. Inventory estimates for selected radionuclides are given in Table 2.1. Most radionuclides listed are included because the radionuclide or its decay product is ex,ected to be an important contributor to lifetime radiation dose. 0ther radionuclides, i.e., noble gases, do not meet this criteria, but are included because their behavior in the atmosphere is of general interest.

Required input for the MLAM transport model includes hourly release rates and release heights for each radionuclide over the entire release period. Neither the USSR (1986) nor IAEA (1986) reports covering the Chernobyl accident provide a complete description of the radionuclide effluent release height and time distribution. The Soviet report (USSR 1986) included two tables relevant to the quantity and time distribution of radionuclide release. Their values are rough estimates and are not presented in sufficient detail to compose a precise time distribution of release. However, it is clear from these reports that the initial explosion carried effluent well above the surface, and that effluent released after the initial explosion had a lower effective release height.

For the purpose of the analysis, radionuclides are assumed to be released over the 10-day period from April 26 to May 5. Rased on a review of available 
TABLE 2.1. Radionuclide Source Term Characterization Used in MLAM Modeling

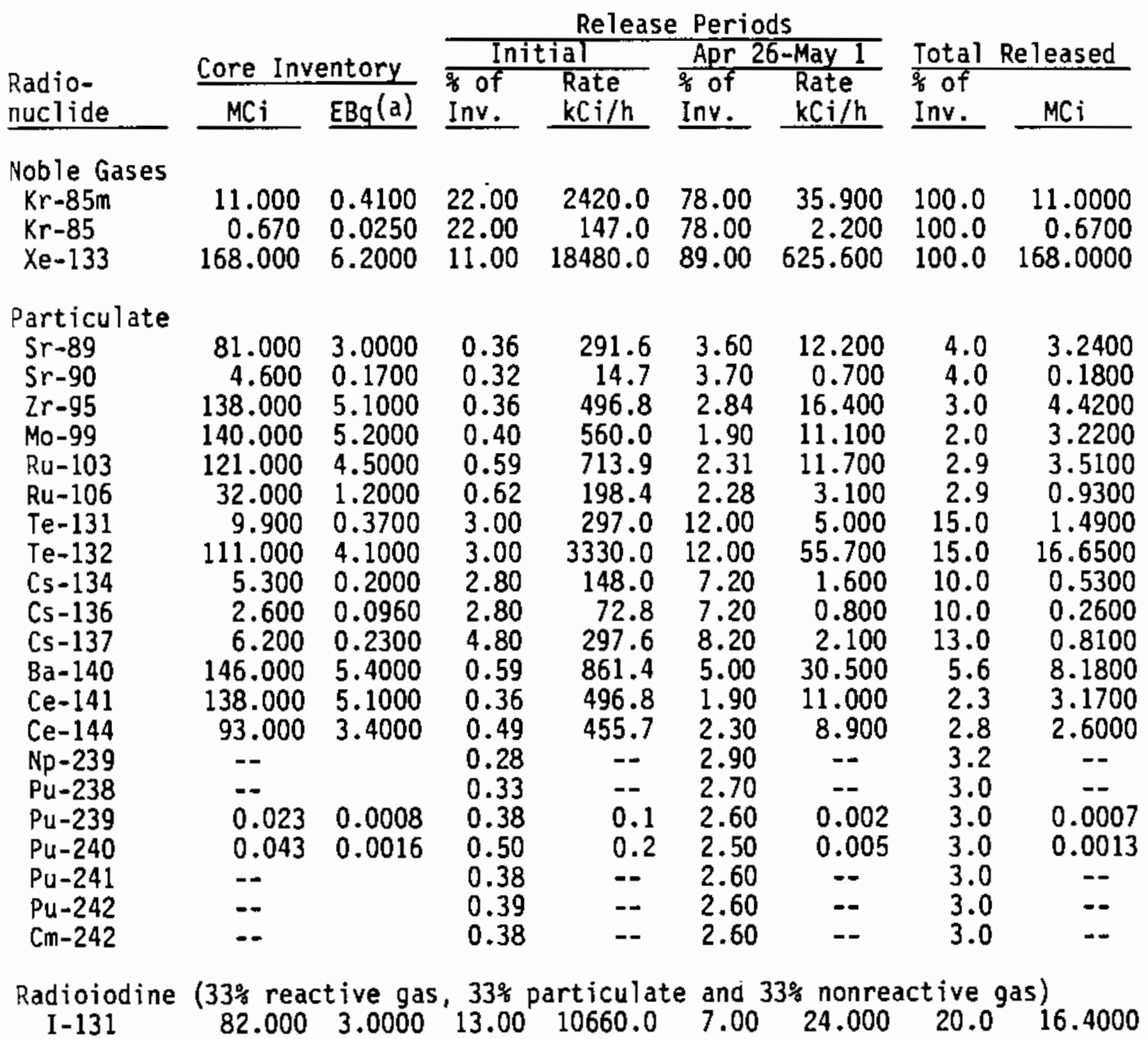

(a) $\mathrm{EBq}=$ exabecquerel $=1018 \mathrm{~Bq}$.

information, two distinct release periods are assumed. The initial release associated with the explosion is assumed to occur during the first hour after the accident. This corresponds to an MLAM puff release at $00 Z$ on April 26. The second release period extends for the next 10 days, ending on May 5 at 23Z. Table 2.1 gives the release rate (in $\mathrm{Ci} / \mathrm{h}$ ) assumed for each release period and radionuclide. In addition, the percent of the reactor core inventory 
represented by this release rate is given. The total amount estimated as being released during the 10 days is also provided.

Release hejghts to be associated with each release period are critical to subsequent transport. Only limited information is provided in available reports. The Soviet report (USSR 1986) stated "According to observers outside unit 4, at about 1:24 a.m. [local time] there occurred two explosions one after the other; burning lumps of material and sparks shot into the air above the reactor, some of which fell onto the roof of the machine room and started a fire." Examination of meteorological sounding data taken near the time of the accident indicates that it is possible that a hot cloud could have risen to about $700 \mathrm{mb}$ where a slight inversion would have hampered continued upward growth. Annex 5 of the Soviet report gives the following description.

"The cloud which formed at the time of the accident produced a radioactive trail on the ground in a westerly and a northeriy direction depending on the meteorological conditions governing the transport of the air masses. Subsequently, for a considerable time, a stream of gaseous, volatile and aerosol products continued to flow from the accident zone. The most intense stream was observed during the first 2-3 days after the accident in the northerly direction, where the radiation levels reached $1000 \mathrm{mr} /$ hour on 27 Apri] and $500 \mathrm{mr} /$ hour on 28 April at a djstance of $5-10 \mathrm{~km}$ from the reactor site (at an altitude of $200 \mathrm{~m}$ ). According to aircraft monitoring data, the height of the stream on 27 April exceeded $1200 \mathrm{~m}$ in the north-westerly direction at about $30 \mathrm{~km}$ from the reactor site, and the radiation levels at that height were about $1 \mathrm{mr} /$ hour. During the following days, the height of the stream did not exceed 200400 m."

Based on information available from Soviet reports, heated plume analyses, and particle fallout analyses, two release heigh: distributions are used. During the initial release period, i.e., first hour of the accident, the source is assumed to be a vertical line extending from the reactor to a height of $2500 \pi$. The vertical line source is modeled by releasing puffs at heights of $300,750,1250,1750$, and $2250 \mathrm{~m}$, midpoints of the atmospheric layers in the MLAM inodel. Uniform release rates are assumed for each layer, i.e., 20\% of the hourly release rate is allocated to each layer. A single release height of $300 \mathrm{~m}$ is assumed for the second release period. 



\subsection{METEOROLOGICAL CONDITIONS AND DATA PREPARATION}

At the time of the accident, the Chernobyl area was under a weak high pressure zone with light and variable surface winds. The sounding at Kiev (Figure 3.1) showed a slight inversion between 920 and $970 \mathrm{mb}$ with a stronger inversion between 700 and $650 \mathrm{mb}$. The winds were 8 to $10 \mathrm{~m} / \mathrm{s}$ from the eastsoutheast at the $850-\mathrm{mb}$ level $(1500 \mathrm{~m})$. Wind speed increased to $13 \mathrm{~m} / \mathrm{s}$ at the $700-\mathrm{mb}$ level. High pressure and low winds continued throughout April 26 and 27. On April 28, the upper-level wind direction shifted to southerly in the morning and west-southwesterly in the afternoon. During this period surface winds remained light and variable. By late afternoon on April 29, the upperlevel wind direction shifted northerly. On May I, surface winds were from the north, and speeds at the surface and upper-levels had increased. Northerly winds persisted for the remainder of the release period. In general, during the release at Chernobyl no precipitation was reported at the reactor site.

On April 28, the transport indicated the initial release had reached the Baltic Sea where it intercepted a warm front (Figure 3.2). The trajectories indicated strong vertical movement over the front, injecting material higher than $4 \mathrm{~km}$ (Davis et a1. 1985). Coincident precipitation with the measured plume occurred as the plume moved over Finland (FCRNS 1986).

After April 29 the general flow pattern shifted, causing the plume in Europe to spread out. On April 30 a cold front (Figure 3.3) extended across Denmark through Germany across France to the northeast corner of Spain. Rain coincident with the plume occurred in Germany resulting in observed iodine-131 deposition exceeding $100,000 \mathrm{~Bq} / \mathrm{m}^{2}$ in southern Germany. From May 2 through May 4 a front moved into Europe (Figure 3.4). The coincidence of the plume and precipitation in the United Kingdom and Europe resulted in numerous reports of radioactivity in precipitation.

Meteorological data required for MLAM computations include wind speed and direction, potential temperature, mixing ratio, surface pressure, mixing height, and precipitation amount. Upper-air radiosonde data were used to obtain the layer-averaged wind speed and direction, potential temperature, and mixing ratio for nine transport layers defined in MLAM. The layer-averaged data were interpolated to a regular three-dimensional grid (Jenne 1970) using inverse distance 


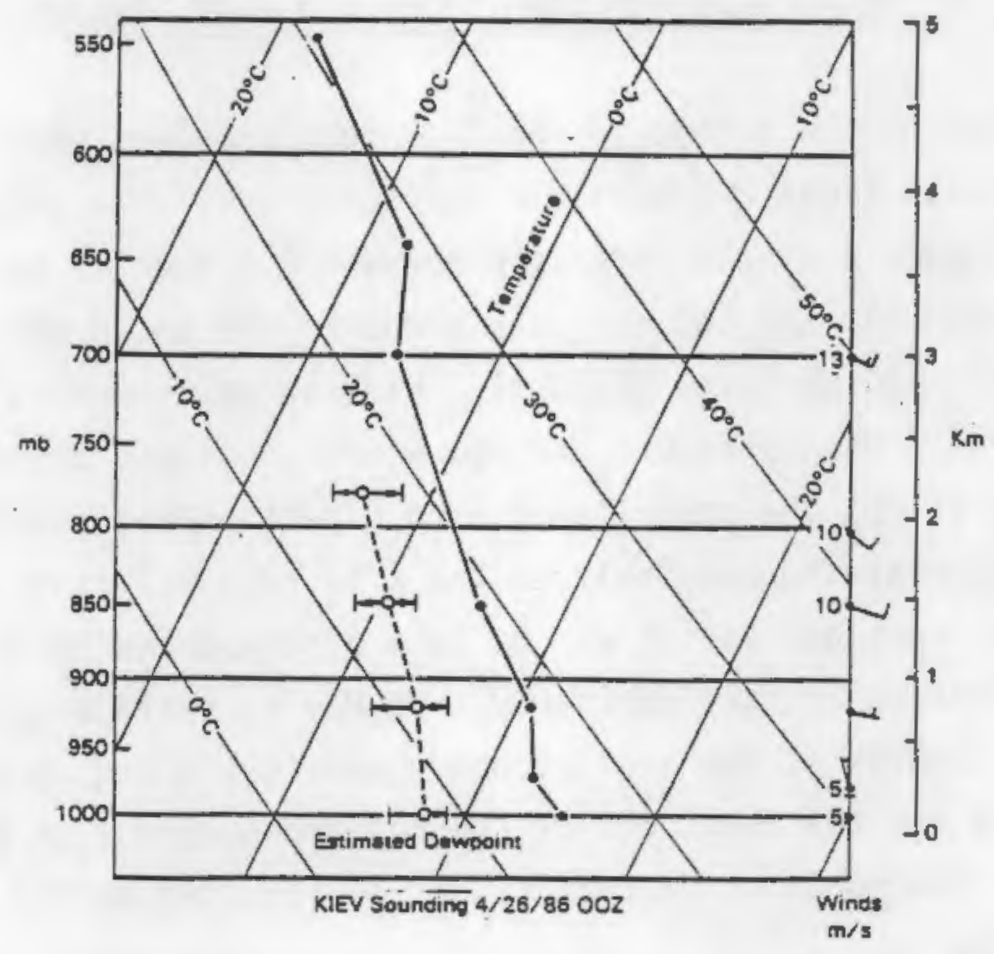

FIGURE 3.1. Kiev Sounding for $00 Z$ April 26, 1986

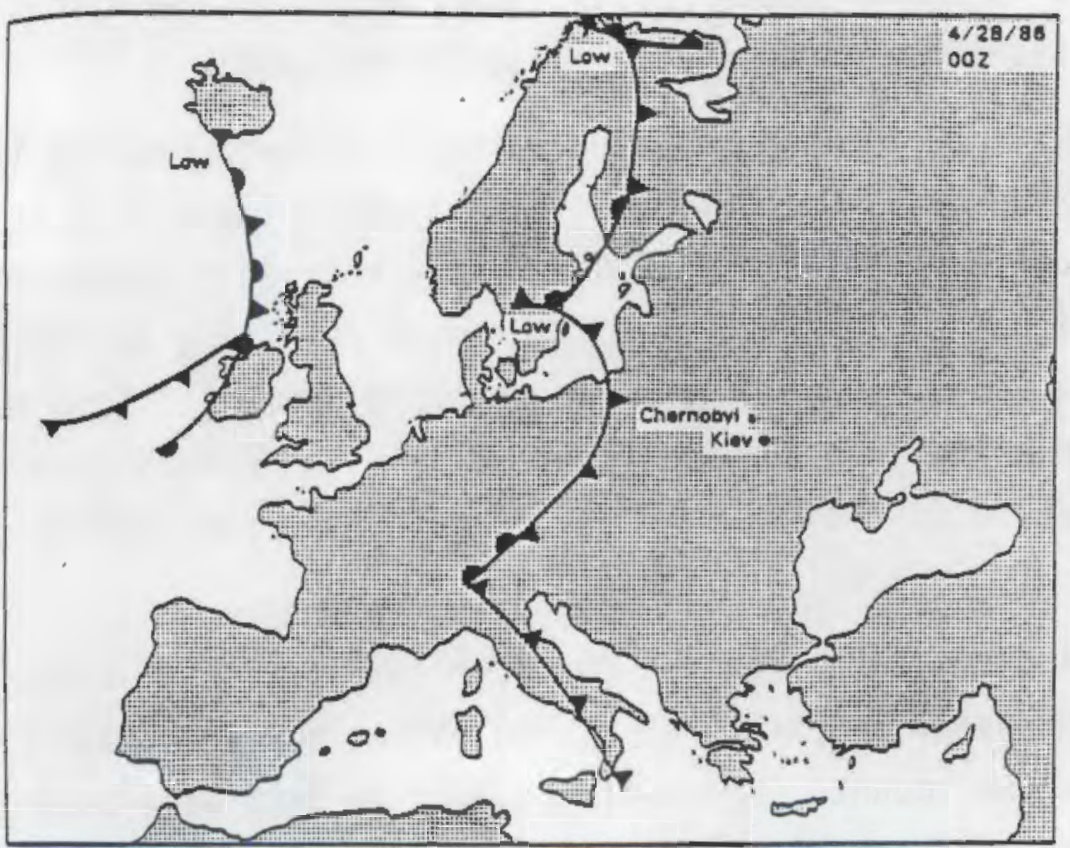

FIGURE 3.2. Surface Fronts over Europe for $00 Z$ April 28, 1986 


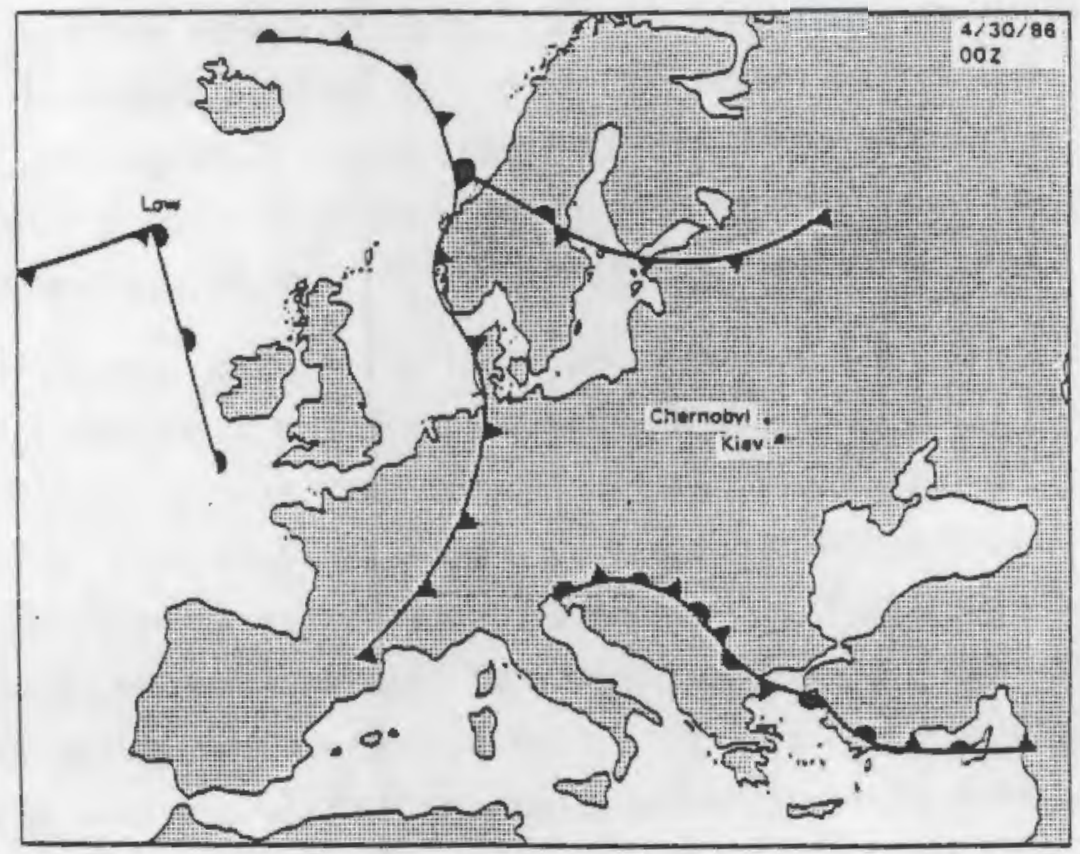

FIGURE 3.3. Surface Fronts over Europe for $00 Z$ April 30, 1986

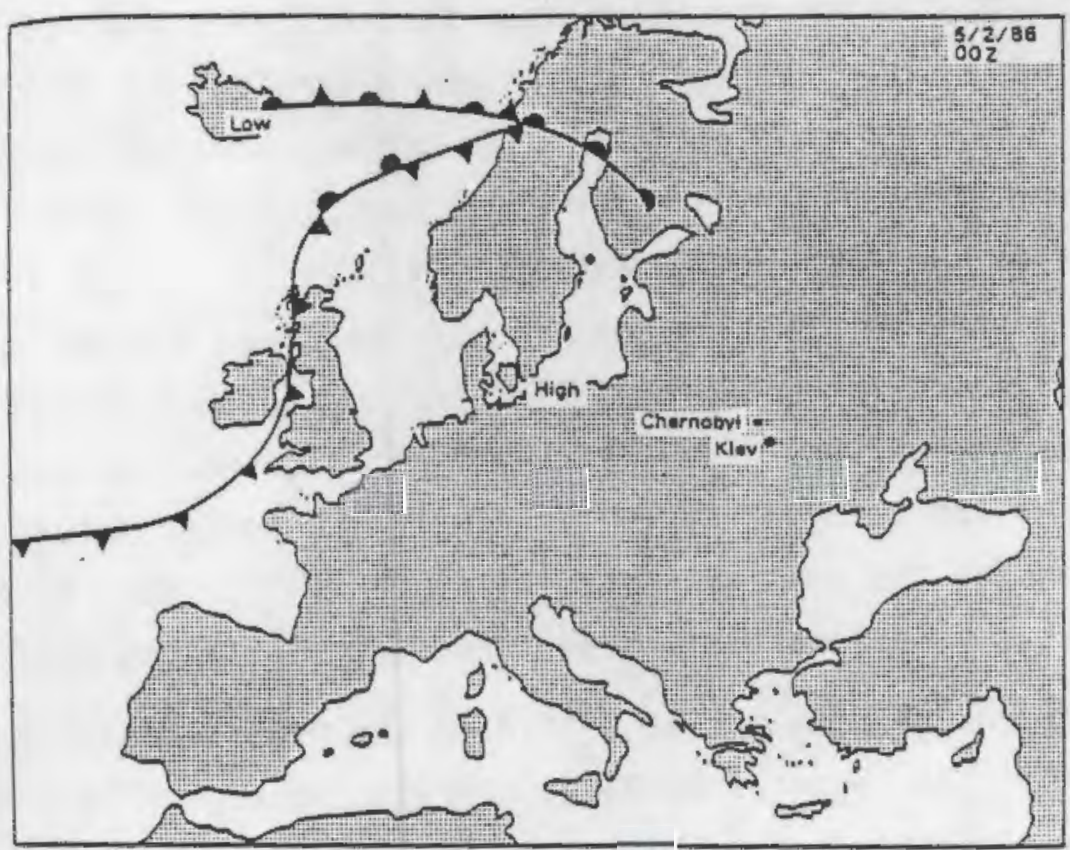

FIGURE 3.4. Surface Fronts over Europe for $00 Z$ May 2, 1986 
squared weighting of stations. Surface pressure and mixing height were interpolated similarly to the surface layer of the three-dimensional grid. An 0.5 NMC grid ( $180 \mathrm{~km}$ at $60^{\circ}$ north latitude, polar stereographic projection) was used for these advection and diffusion-related quantities. A finer mesh, 0.1 NMC grid was used in the computation of air concentrations and deposition.

Upper-air meteorological data were collected from several organizations, including NAMER tapes from the National Oceanic and Atmospheric Administration (NOAA). Although substantial duplication of data existed from these sources, an extensive effort was undertaken to combine the data sets to create the best available data coverage for the region of interest. A review of the merged data indicated that a sufficient number of stations reported at $00 Z$ and $12 z$ to justify creation of grids for those time periods; but that $06 z$ and 182 had an insufficient number of reporting stations to justify creating grids at these times.

MLAM includes a provision for hourly precipitation input on a fine-mesh grid. An effort was made to obtain hourly, 3-hourly, or 6-hourly precipitation data for all available surface stations in western and eastern Europe. After obtaining one 6-hourly precipitation data set, ar investigation of the data quality showed that the coverage was so incomplete that its use could not be justified. A NOAA 24-h precipitation data set was obtained that appeared to account for known precipitation occurrences and provided the coverage required. The 24-h precipitation amount was uniformly allocated throughout the 24-h period. When 24-h precipitation amounts were reported for periods spanning 2 days, precipitation was uniformly allocated over a $48-h$ period. This assumption means that, in certain areas, the precipitation will be extended beyond the times over which it occurred and at a greatly reduced intensity. The process of gridding the available precipitation station data also tends to extend precipitation estimates to areas where precipitation did not occur.

Wet deposition results are sensitive to the precipitation data and associated assumptions. As reported by Davis (1979), the use of 24-h data will cause an overestimation in the total amount deposited. For example, model results show the occurrence of wet deposition downwind of Chernobyl during the initial release period when no wet deposition occurred. This deposition is the result of assuming the precipitation occurred throughout the 24-h period 
rather than having occurred before or after the cebris arrived. A second problen occurs with the use of 24-hour precipitation. If plume arrival and precipitation are coincident in time and space, then the use of $24-h$ precipitation will tend to underestimate the amount deposited. This results from the nearly linear dependence of the removal rate with precipitation rate. If precipitation occurs over a 6-h time span instead of $24 \mathrm{~h}$, then the rate of removal is four times larger than computed at that location. Since Finland reported the coincident occurrence of plume and rain (FCRNS 1986), a reasonable assurance exists that the amount of deposition in Finland is underestimated. Further, when precipitation occurs downwind of the precipitation in Finland, the amount deposited is likely to be overestimated because of the increased amount available from the previous underestimation of removal. 



\subsection{MLAM MODEL ASSUMPTIONS}

The current version of MLAM is a modification of the earlier MLAM model developed by Davis et al. (1986) for use with inert tracers in CAPTEX. Davis and Wendell (1976) and Davis (1983) developed prior versions for use in acid rain work (Davis and Glantz 1986).

MLAM is a Lagrangian puff model that releases puffs at one or more sources and advects and disperses the puffs on hourly time steps. Puffs are transported for a maximum of 10 days. Transport in three dimensions is based on gridded fields of potential temperature, wind speed and direction, and mixing ratios. Nine vertical layers are used to incorporate vertical motion of a puff based on differences in potential temperature (puff unsaturated) or equivalent potertial temperature (puff saturated). The MLAM model was run for this study using nine layers defined by boundary values of 100,500,1000,1500, 2000, $2500,3000,4000,5000$, and $6000 \mathrm{~m}$. During periods of atmospheric mixing, the mode1, in a manner similar to that described by Draxler and Taylor (1982), redistributes the mass of a puff into multiple layers. The height over which the vertical redistribution occurs is computed from the mixing height derived from the maximum daily mixing height and an assumed daily sinusoidal curve. The frequency of redistribution was selected to occur once a day at 4:D0 p.m. LST. Horizontal diffusion is calculated using a diffusion parameterization calculated by Heffter (1965): $\sigma_{y}=0.5 t$ where $\sigma_{y}$ is the horizontal diffusion parameter in meters and $t$ is the elapsed time in seconds. Vertical diffusion is ca"culated based on diurnal variation in stability combined with the tabled values based on the work of Eimutis and Konicek (1972).

Two grids were used within MLAM. The larger grid (not shown) covers most of the northern hemisphere and was used for puff transport. The grid is based

on the National Meteorological Center (NMC) northern hemisphere, octagonal grid (Jenne 1970). The larger grid is twice as dense (0.5 NMC grid spacing) as the grid documented by Jenne. Grid distance is approximateiy $190.5 \mathrm{~km}$ at $60^{\circ}$ north latitude. This larger grid is used for the representation of gridded data fields described in Section 1. The smaller, fine-mesh grid (Figure 4.1) covers Europe and the western USSR. The smaller grid is also based on the NMC grid but has a grid spacing of 0.1 NMC (approximately $38.1 \mathrm{~km}$ at $60^{\circ}$ north 


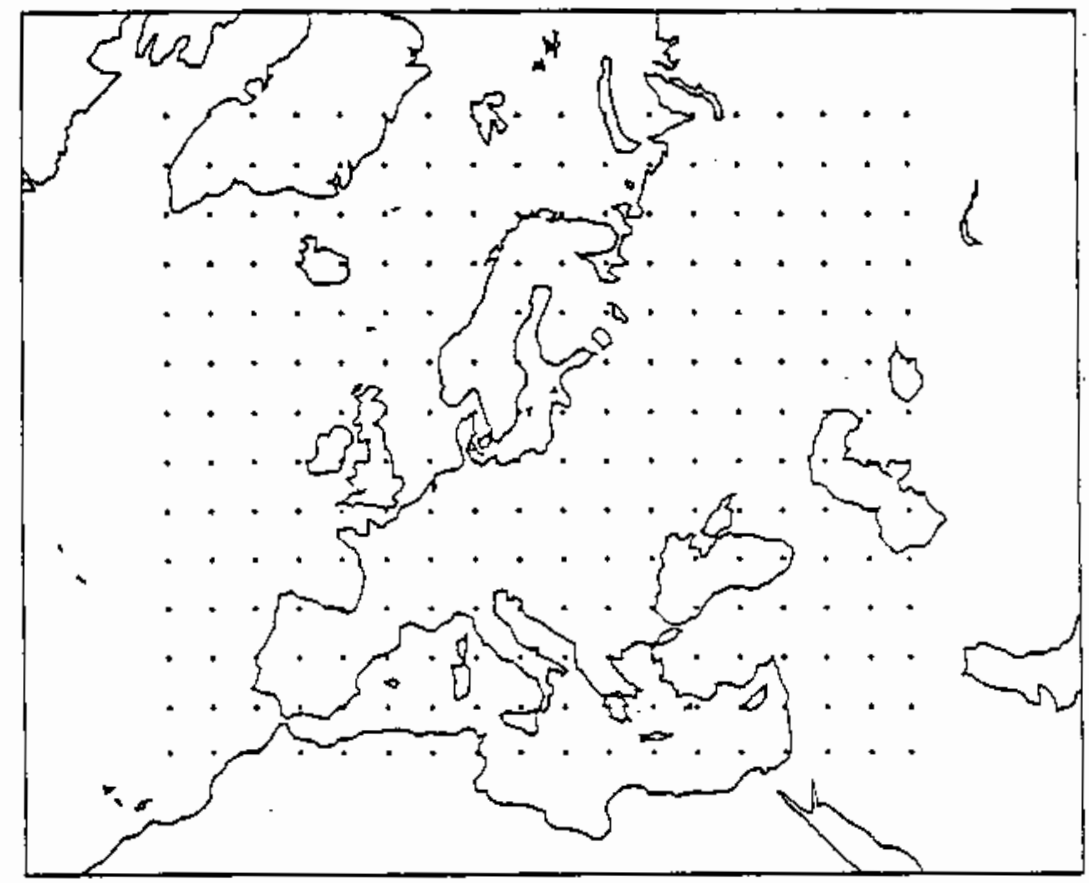

FIGURE 4.1. Outline of Fine-Mesh Deposition Grid

latitude). This fine-mesh grid $(22,100$ grid cells) is used in the computation of area wet and dry deposition and daily averaged area air concentration. The gridded precipitation field described in Section 3.2 uses the same finemesh grid. The outline of this grid is shown in Figure 4.1 with only every tenth grid node displayed, i.e., the standard NMC grid.

For each radionuclide 7 isted in Table 2.1, daily wet and dry deposition and daily averaged air concentration are computed for each grid cell of the 0.1 NMC grid. Computations are performed hourly but are accumulated to daily values. The daily values are based on GMT days (00Z to 24Z). Because daily values are given, nuclide decay was computed to noon of the day. Nuclide decay to progeny nuclides is not accounted for in MLAM.

To compute air concentration and deposition (wet and dry), it is necessary to determine the horizontal diffusion of each puff. Horizontal diffusion of a puff is used to determine the amount of each nuclide, released into a puff, influencing a grid cell. Once the grid cells influenced by a puff are determined, the Gaussian diffusion of the puff to the surface is used to calculate surface air concentrations for these grid cells for each nuclide. The wet 
and dry depositions are calculated similarly but require the use of experimentally derived coefficients for each nuclide.

In MLAM the wet and dry deposition tems used for a nuclide are associated with three types: noble gases, particulates, and reactive iodine gas.

Table 4.1 gives the deposition velocity used for dry deposition and the washout coefficients used for wet deposition for each type of nuclide. Washout coefficients for wet deposition depend on whether the puff is saturated or unsaturated. In MLAM, puff saturation occurs when the relative humidity within the fuff reaches $100 \%$. Washout coefficients are based on a study of wet removal in Cabriolet (Larson et al. 1968). If the puff is saturated and encounters precipitation, then the puff experiences in-cloud scavenging. If puff is not saturated and precipitation is encountered, then the puff experiences belowcioud scavenging and washout coefficients are reduced by an order of magnitude. Inert iodine gas is treated as a noble gas while iodine on particulates is assumed to deposit and wash out as a particulate. Reactive iodine gas is treated separately, as shown in Table 4.1 .

IABLE 4.1. Deposition Velocities and Washout Coefficients for Radionuclide Deposition

\begin{tabular}{|c|c|c|c|}
\hline \multirow[b]{2}{*}{$\begin{array}{l}\text { Type of } \\
\text { Radionuc lide }\end{array}$} & \multirow{2}{*}{$\begin{array}{c}\text { Dry } \\
\text { Deposition } \\
\text { Velocity } \\
(m / h) \\
\end{array}$} & \multicolumn{2}{|c|}{$\begin{array}{c}\text { Wet Deposition } \\
\text { Washout Coefficients }\end{array}$} \\
\hline & & $\begin{array}{l}\text { puff saturated } \\
\text { (per hour) }\end{array}$ & $\begin{array}{l}\text { puff unsaturated } \\
\text { (per hour) }\end{array}$ \\
\hline Noble Gases & 0 & 0 & 0 \\
\hline Particulates & 3.6 & $0.6 P 0.9$ & $0.06 p 0.9$ \\
\hline Iodine Gas & 36 & $2.0 p 0.9$ & $0.2 p 0.9$ \\
\hline
\end{tabular}


$\therefore$ 


\subsection{LIFETIME RADIATION DOSES}

The purpose of the radiation dose calculations performed for this study was to define the potential long-term impact of the radionuclides deposited on the ground in the study area as a result of the Chernobyl reactor accident. The radiation doses contributed by inhalation and direct deposition on food products were not modeled. These latter doses have been defined by direct measurements of concentrations of radionuclides in air and foods in many of the countries in our study region. Addition of local estimates of initial doses made by other investigators to estimates of long-term doses reported here should not bie attempted without careful analysis of the differing bases for the several sets of calculations and the overlapping time periods involved.

\subsection{PABLM RADIATION DOSE MODEL}

Lifetime (70-year) radiation doses were calculated using the computer code PABLM (Napier, Kennedy and Soldat 1980). This code is designed to calculate accumulated doses from the chronic ingestion of food products that contain radionuclides and from external exposure to radionuclides in the environment. The radiation dosimetry is based on the model defined in Publication 2 of the International Commission on Radiological Protection (ICRP 1959). Accumulated doses can be calculated for 23 possible body organs or tissues for any combination of radionuclides. A maximum of 5 organs and 100 radionuclides may be selected in any one case. Any combination of 19 ingestion (or food-product) pathways may be selected with corresponding consumption rates, growing periods, and air or water concentrations and deposition rates. A total of four external expostre pathways may also be selected with corresponding exposure times and soil, air, or water concentrations.

For all exposure pathways chosen, radionuclides may continue to be released for a long time (as during the operating lifetime of a facility), or may only be released for a short time (as in an accident). After the release has ceased, deposited radionuclides remain in the soil and are assumed to be removed only by radioactive decay. Pathways of exposure are selected by the user on the basis of the type of effluent (gaseous or aqueous) and the type and amount of crops grown in the area of interest. 
The PABLM code includes tabulations of precalculated external exposure factors that can be combined with internally calculated concentrations in environmental media to calculate external doses to whole body or skin. The code also contains tabulations of concentration ratios for $\mathrm{plant} / \mathrm{soi}$, animal products/animal diet, and aquatic organisms/water.

Internal radiation doses are calculated as a function of radionuclide concentration in food products, ingestion rates, and radionuclide-specific dosecommitment factors. The concentration in food varies with time, with release rate, and with buildup and decay in the soil. The ingestion rate of food products is assumed to be constant with time. The dose commitment is calculated for each year of intake, out to the end of the dose period. The accumulated dose is the sum of the series of annual dose commitments.

\subsubsection{Radiation Doses to Individuals}

For the purposes of the current study, the PABLM code was used to calculate the external and internal doses that would result from an initial deposition of a unit concentration of each radionuclide on the ground, exclusive of the initial contamination of the aboveground portions of growing vegetation. The doses were calculated assuming exposure began 20 days following the initial radionuclide release from the reactor. This time corresponds to the end of the transport period used in the atmospheric dispersion code. For the ingestion pathway, only leafy vegetables, milk, and beef were considered, with average diets of $300 \mathrm{~kg} / \mathrm{yr}, 200 \mathrm{~L} / \mathrm{yr}$ and $50 \mathrm{~kg} / \mathrm{yr}$, respectively. These diets are not necessarily applicable to all the populations for which doses were calculated; however, nore specific diets were not available.

Lifetime (70-yr) committed doses were calculated for two exposure periods: $1 \mathrm{yr}$ and $70 \mathrm{yr}$. The first-year committed dose includes the exposure that results from ingestion of locally grown contaminated (via uptake from soil) foodstuffs and external exposure to contaminated ground $24 \mathrm{~h}$ per day during the first year. (This latter assumption is conservatively high by a factor of 2 or 3 because no credit was taken for the time individuals spent indoors.)

The 70-yr accumulated dose considers the exposure that results from $70 \mathrm{yr}$ of consumption of foods locally grown in contaminated soil, and external 
exposure $(24 \mathrm{~h} /$ day) to contaminated soil. Soil concentrations were calculated for each year of exposure by applying corrections for radioactive decay to the initial deposition values.

The total radiation doses to the average individual were calculated by multiplying the unit dose factors for each radionuclide by the quantities of the radionuclide calculated by the atmospheric diffusion code (MLAM) to have been deposited on the ground.

\section{1 .2 Collective Radiation Doses}

Although the total deposition in the study area was calculated on a 130 by $170 \mathrm{grid}$, the population data were estimated on a scale that was 10 times as coarse as the deposition data. That is, one population number was given for each 100 squares (an area 10 nodes by 10 nodes) on the MLAM grid. The accuracy of the population data and of the location of the countries' boundaries on the grid map did not warrant an attempt at any finer detail for the population distribution.

The population for each country and each individual Soviet republic within the study area was taken from the World Almanac (Hoffman 1986). These data were partitioned into the number of persons for each grid square by estimating (on the grid map) the fraction of the land area of each country that was inside the square, coupled with the assumption of a uniform population density across the country. For example, if $10 \%$ of the land area of country $\mathrm{C}$ fell in grid area $A$, it was assumed that $10 \%$ of the persons in country $C$ each received the individual doses calculated from the radionuclide deposition in grid area $A$. The estimate of the total collective comitted dose for country $C$ was then compiled by adding the contributions from each grid area that contained a portion of that country.

\subsection{LIFETIME RADIATION DOSE RESULTS}

Potential post-accident, long-term radiation doses to the population of the western USSR and Europe were estimated based on the total deposition calculated by the MLAM model. 


\subsubsection{Radiation Doses to Individuals}

The radiation doses are calculated for individuals residing for a lifetime at each grid point and consuming foods raised at that same location. The results of these calculations are illustrated in Figures 5.1 and 5.2 in the form of spatial patterns for Europe and then expanded to provide more detail for eastern Europe. To aid the reader in associating map regions with specific locations, Figure 6.1 in Section 6 gives corresponding base maps with selected cities identified and latitude and longitude lines included. Figure 5.1 depicts the calculated individual lifetime doses for a 70-yr exposure period across the entire and eastern portion of the study grid, respectively. Figure 5.2 gives corresponding individual lifetime doses for a 1 -yr exposure period.

The highest dose category for the 70 -yr exposure period is 10 to $100 \mathrm{mSv}$ ( 1 to $10 \mathrm{rem}$ ). The region receiving this dose extends northwest toward finland, south to the Black Sea, and northeast toward Moscow. Reflecting steep gradients in total deposition, dose estimates drop to less than $0.01 \mathrm{mSv}$ within tens of kilometers of the high dose region. Because the same diet was assumed for all locations, the dose contours in the figures directly reflect the calculated total deposition. In contrast, the highest dose category for the 1-yr exposure period is 1 to $10 \mathrm{mSv}$ and does not extend as far from Chernobyl. The maximum dose around the reactor is based on the assumption that no permanent prohibition is enforced against living and farming in that area.

Dose estimates for western Europe are less than $0.10 \mathrm{mSv}$ and $0.01 \mathrm{mSv}$ for the 70-yr and 1-yr exposure periods, respectively. Most of Eastern Europe and north-central USSR have $70-y r$ exposure dose estimates greater than $0.10 \mathrm{mSv}$ (10 mrem), with the eastern portion generally exceeding $1.0 \mathrm{mSv}(0.1 \mathrm{rem})$.

The MESORAD dose assessment completed by Ramsdell et al. (1987) estimated total whole-body dose within $80 \mathrm{~km}$ of the reactor. Total whole-body dose is defined as the sum of external doses from the passing plume and shine from ground contamination, and a 50-yr dose commitment from inhaled radionuclides. By the beginning of May 7, 1986, the MESORAD assessment indicates that, within $80 \mathrm{~km}$, total whole-body dose exceeded $0.1 \mathrm{rem}$ and that approximately $20 \%$ of the area within $80 \mathrm{~km}$ had accumulated a whole body dose of 1.0 rem or more. No precipitation occurred within $80 \mathrm{~km}$ of the reactor during the assessment 


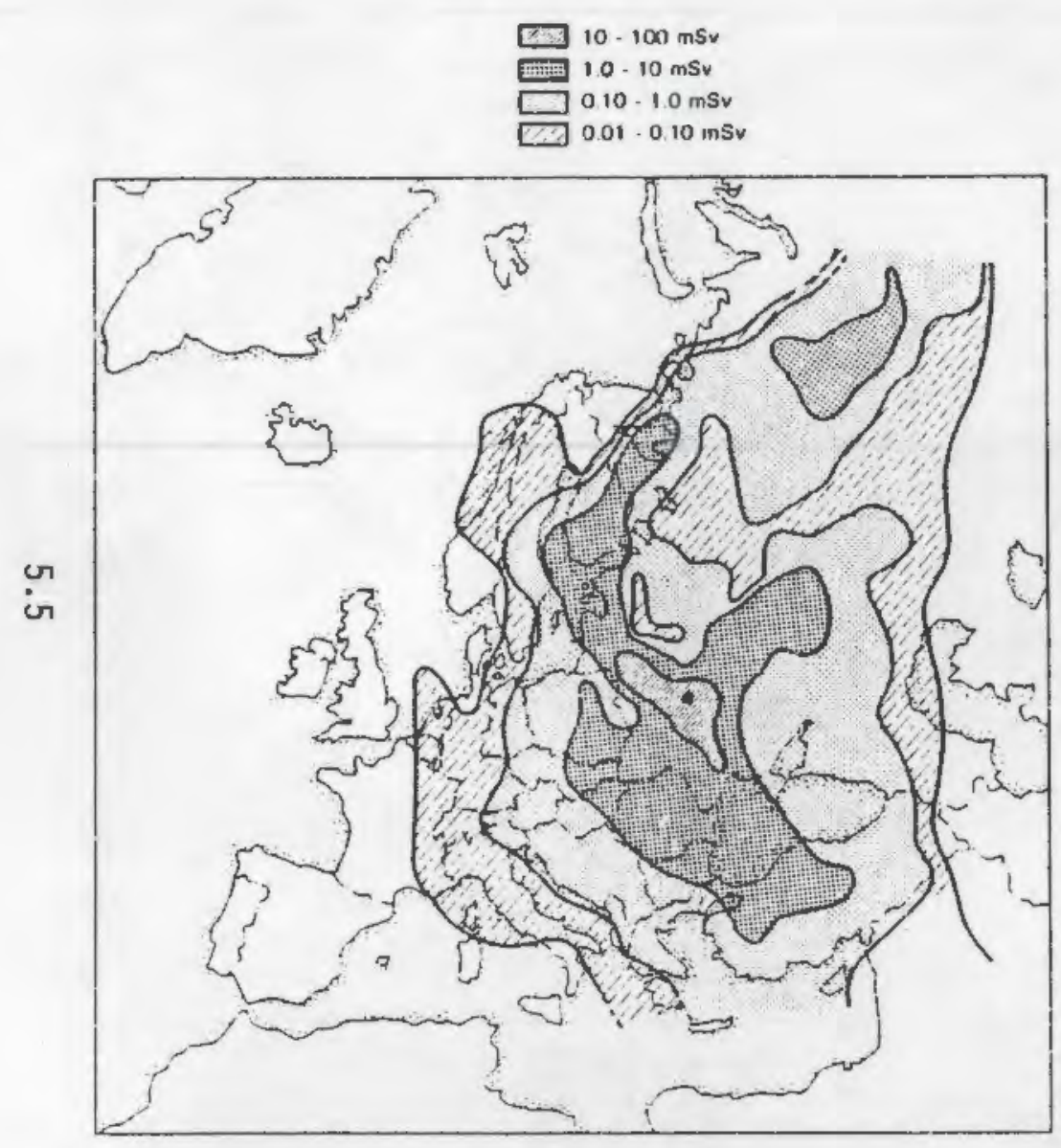

(a)

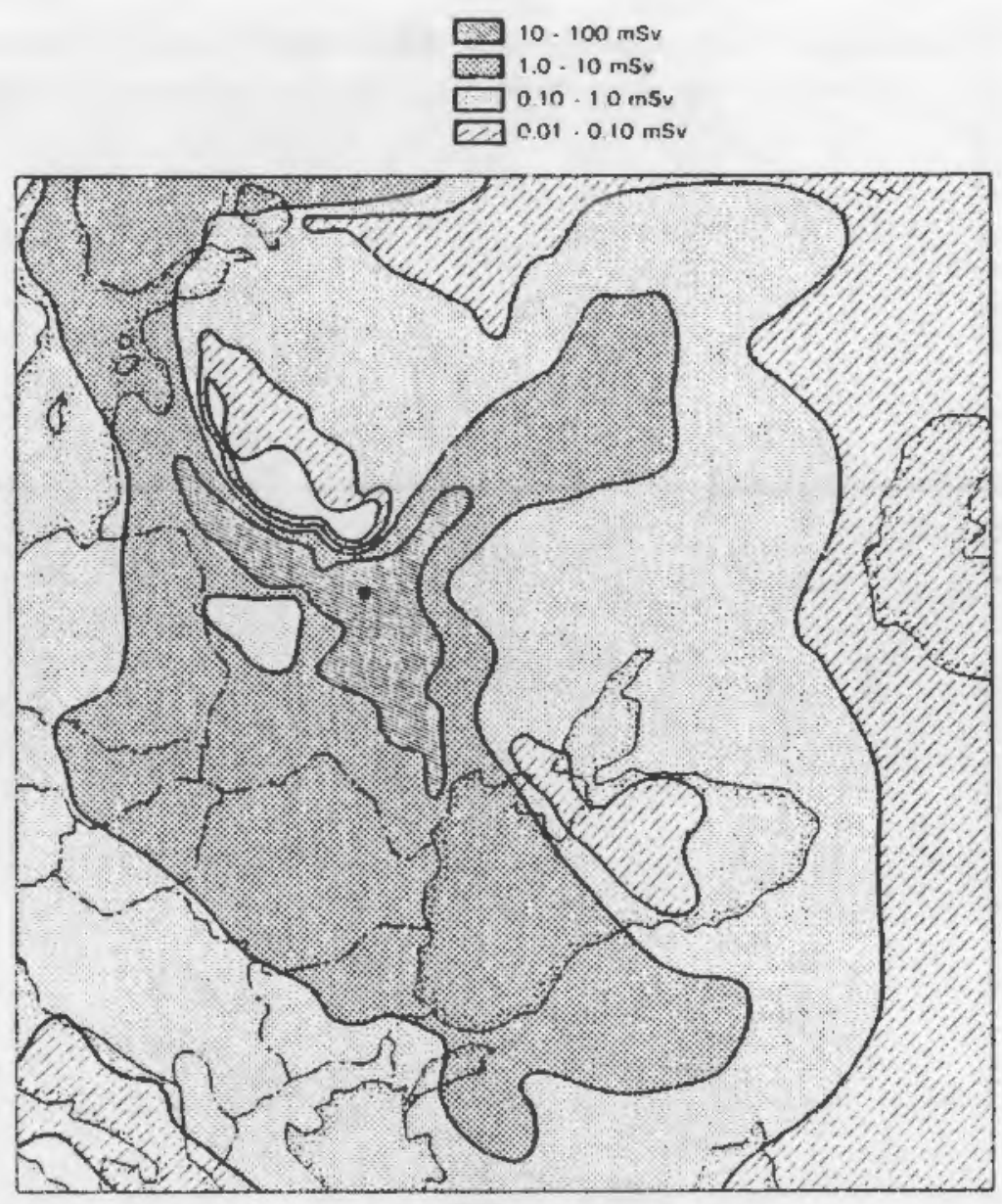

(b)

FIGURE 5.1. Lifetime Radiation Doses to Individuals from 70-yr Exposure to Residual Contamination on the Ground and in Food (mSv), (a) Europe and (b) Eastern Europe 


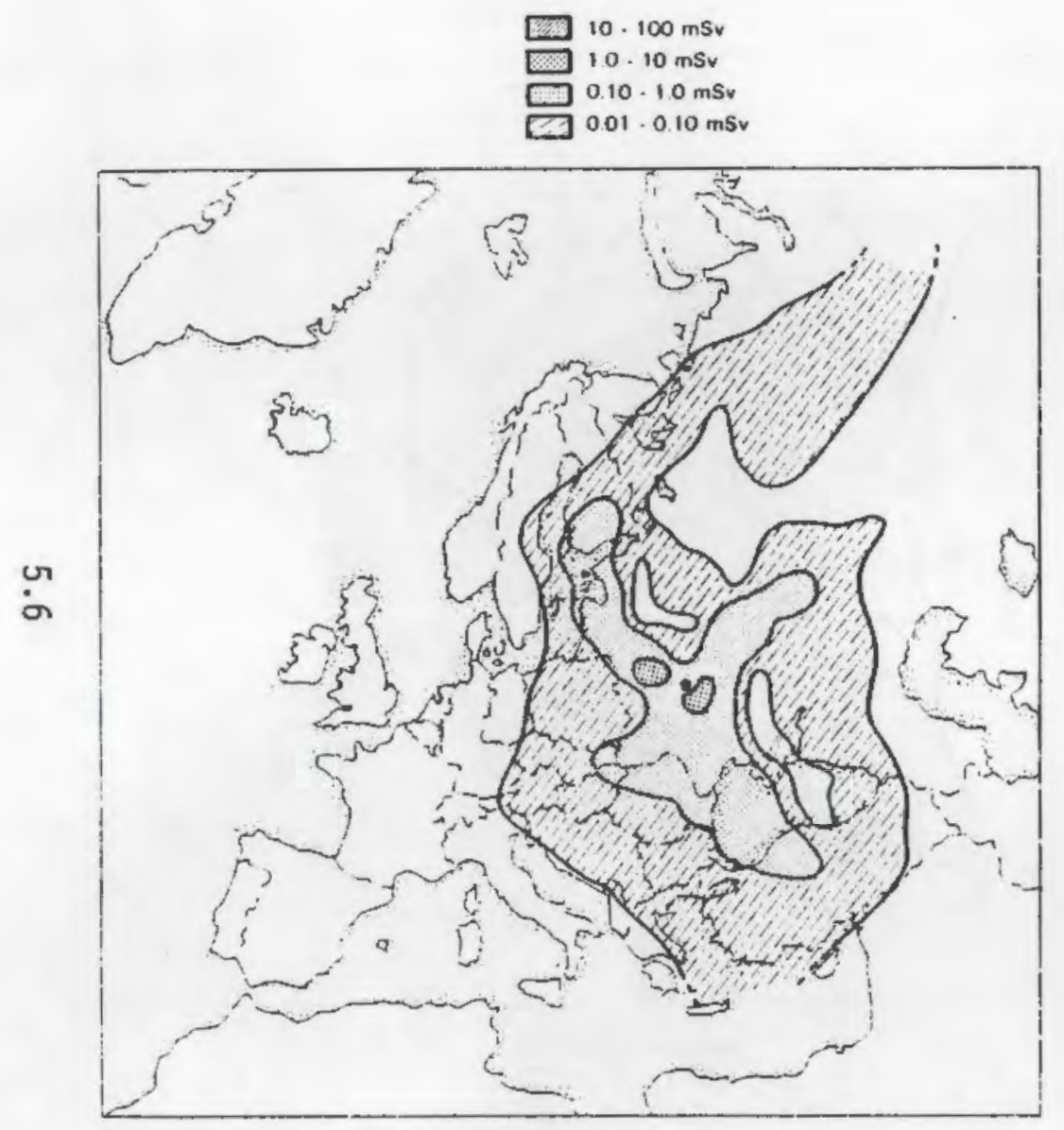

(a)

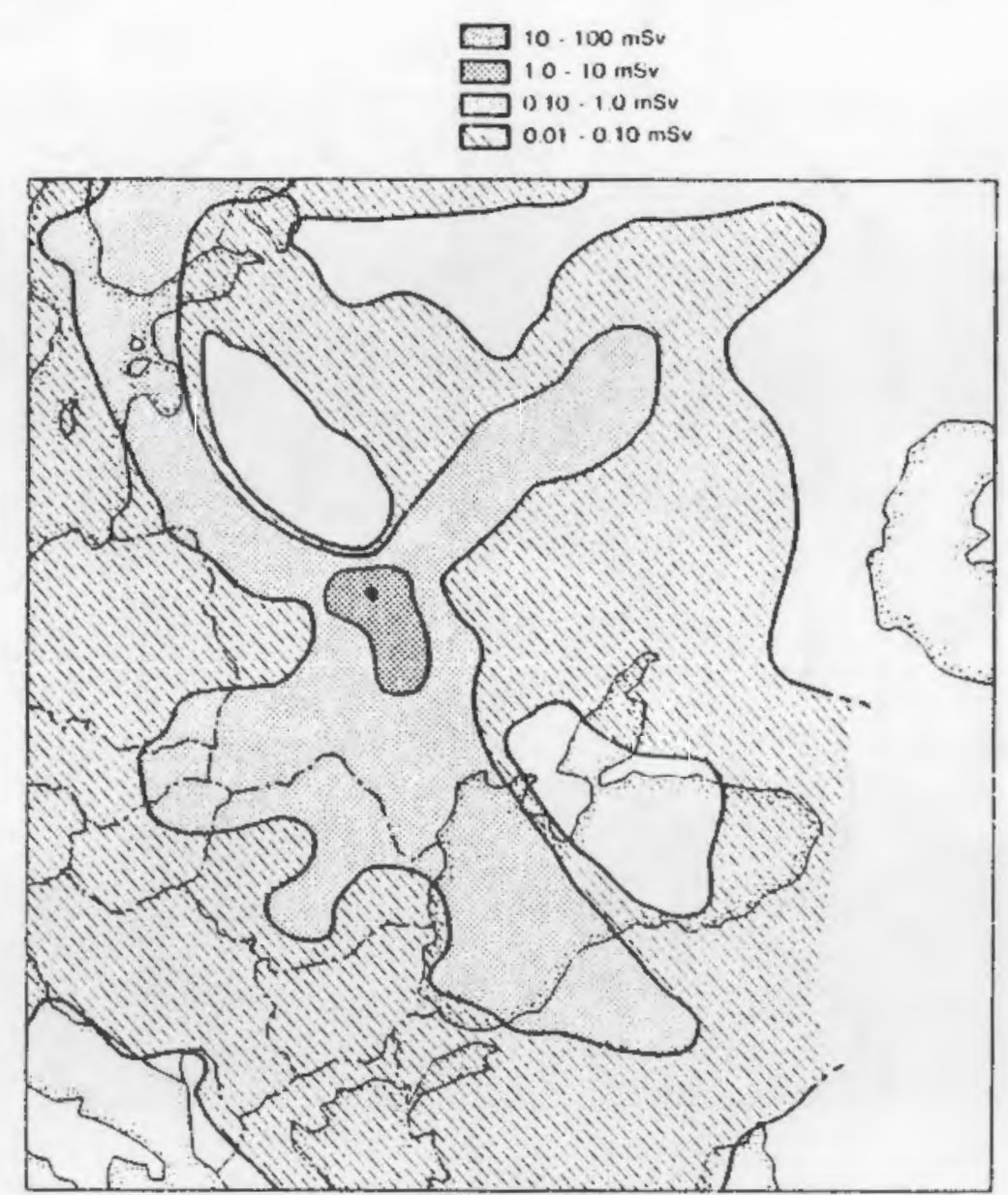

(b)

FIGURE 5.2. Lifetime Radiation Doses to Individuals from 1-yr Exposure to Residual Contamination on the Ground and in Food (mSv), (a) Europe and (b) Eastern Europe 
period and so no wet deposition occurred. This assessment does consider precipitation that occurred in the high-dose region, resulting in increased deposition.

\subsubsection{Population Dose By Country}

The calculated lifetime collective radiation doses for individual countries are calculated from the estimated individual doses for each grid node by applying the appropriate population data. The results are presented in Table 5.1. The total collective dose obtained in this study, 0.54 million person-sieverts, is less than half of that obtained by the Committee on the Assessment of Health Consequences in Exposed Populations (DOE 1987). The distribution dose by pathway is also different in these two studies. The Committee's study results indicate that about $30 \%$ of the total dose will be contributed by ingestion, while this study indicates that only $15 \%$ of the total collective dose will result from ingestion.

For the portion of the USSR included in the study area, the total collective dose is 0.34 million person-sieverts. In comparison, the total dose is 0.20 million person-sieverts for Europe. An average per-person dose estimate for the USSR and Europe, based on region population dose estimates, are $3.1 \mathrm{mSv}$ $(0.31 \mathrm{rem})$ and $0.4 \mathrm{mSv}(0.04 \mathrm{rem})$ respectively. Within the USSR, the collective population dose for the Ukraine is 0.26 million person-sieverts ( $5.2 \mathrm{mSv}$ average per person dose) and for Byelorussia is $0.016 \mathrm{million}$ person-sieverts (1.7 $\mathrm{mSv}$ average per person dose).

Calculated population doses for total deposition are generally higher than doses based on dry deposition only. For Europe, the respective values are 200,000 and 170,000 person-sieverts and for the western USSR, 340,000 and 320,000 person-sieverts. An exception is the United Kingdom, with 140 and 280 person-sieverts, where the total deposition case value is lower. Doses for total deposition are higher in countries in Scandinavia and northern Europe where rain is reported to have created localized "hot spots." Also, as expected, doses calculated for countries "downwind" of areas where it rained tend to be lower for the total deposition case than for the dry case. In Finland, population dose for total deposition (Table 5.1) is calculated as 
TABLE 5.1. Estimated Lifetime (70-yr) Population Doses from Total (Dry and Wet) Deposition of Radicnuclides in Europe Following the 1986 Chernobyl Accident

\begin{tabular}{|c|c|c|c|c|}
\hline & & & on-Siever & \\
\hline Country & Population (a) & Internal & External & TotaT \\
\hline Europe & & & & \\
\hline $\begin{array}{l}\text { Albania } \\
\text { Austria } \\
\text { Belgium } \\
\text { Bulgaria } \\
\text { Czechos lovakia } \\
\text { Denmark } \\
\text { Finland } \\
\text { France } \\
\text { Germany, East } \\
\text { Germany, West } \\
\text { Greece } \\
\text { Hungary } \\
\text { Iceland } \\
\text { Ireland(b) } \\
\text { Italy(c) } \\
\text { Luxembourg } \\
\text { Netherlands } \\
\text { Norway } \\
\text { Poland } \\
\text { Portugal (b) } \\
\text { Romania } \\
\text { Spain(b) } \\
\text { Sweden } \\
\text { Switzerland } \\
\text { Turkey(d) } \\
\text { Yugoslavia }\end{array}$ & $\begin{array}{l}2.9 \mathrm{E}+06 \\
7.6 \mathrm{E}+06 \\
9.9 \mathrm{E}+06 \\
9.0 \mathrm{E}+06 \\
1.6 \mathrm{E}+07 \\
5.1 \mathrm{E}+06 \\
4.9 \mathrm{E}+06 \\
5.5 \mathrm{E}+07 \\
1.7 \mathrm{E}+07 \\
6.1 \mathrm{E}+07 \\
9.9 \mathrm{E}+06 \\
1.1 \mathrm{E}+07 \\
2.4 \mathrm{E}+05 \\
3.6 \mathrm{E}+06 \\
5.7 \mathrm{E}+07 \\
3.7 \mathrm{E}+05 \\
1.4 \mathrm{E}+07 \\
4.1 \mathrm{E}+06 \\
3.7 \mathrm{E}+07 \\
1.0 \mathrm{E}+07 \\
2.3 \mathrm{E}+07 \\
3.8 \mathrm{E}+07 \\
8.3 \mathrm{E}+06 \\
6.5 \mathrm{E}+06 \\
5.1 \mathrm{E}+07 \\
2.3 \mathrm{E}+07\end{array}$ & $\begin{array}{l}1.1 \mathrm{E}+02 \\
4.4 \mathrm{E}+02 \\
3.4 \mathrm{E}+01 \\
1.6 \mathrm{E}+03 \\
2.7 \mathrm{E}+03 \\
1.6 \mathrm{E}+01 \\
3.4 \mathrm{E}+02 \\
1.0 \mathrm{E}+02 \\
3.3 \mathrm{E}+02 \\
7.0 \mathrm{E}+02 \\
4.8 \mathrm{E}+02 \\
2.1 \mathrm{E}+03 \\
7.1 \mathrm{E}-03 \\
1.7 \mathrm{E}-01 \\
6.4 \mathrm{E}+02 \\
2.0 \mathrm{E}+00 \\
4.1 \mathrm{E}+01 \\
2.0 \mathrm{E}+01 \\
6.6 \mathrm{E}+03 \\
0.0 \mathrm{E}+00 \\
7.9 \mathrm{E}+03 \\
1.0 \mathrm{E}-01 \\
2.6 \mathrm{E}+02 \\
7.8 \mathrm{E}+01 \\
6.4 \mathrm{E}+03 \\
1.8 \mathrm{E}+03\end{array}$ & $\begin{array}{l}5.1 \mathrm{E}+02 \\
2.1 \mathrm{E}+03 \\
1.6 \mathrm{E}+02 \\
7.9 \mathrm{E}+03 \\
1.3 \mathrm{E}+04 \\
7.9 \mathrm{E}+01 \\
5.3 \mathrm{E}+03 \\
5.0 \mathrm{E}+02 \\
1.6 \mathrm{E}+03 \\
3.4 \mathrm{E}+03 \\
2.3 \mathrm{E}+03 \\
1.0 \mathrm{E}+04 \\
3.4 \mathrm{E}-02 \\
8.3 \mathrm{E}-01 \\
3.1 \mathrm{E}+03 \\
9.8 \mathrm{E}+00 \\
2.0 \mathrm{E}+02 \\
1.0 \mathrm{E}+02 \\
3.7 \mathrm{E}+04 \\
0.0 \mathrm{E}+00 \\
3.8 \mathrm{E}+04 \\
4.9 \mathrm{E}-01 \\
2.4 \mathrm{E}+03 \\
3.7 \mathrm{E}+02 \\
3.1 \mathrm{E}+04 \\
8.7 \mathrm{E}+03\end{array}$ & $\begin{array}{l}6.1 \mathrm{E}+02 \\
2.6 \mathrm{E}+03 \\
1.9 \mathrm{E}+02 \\
9.5 \mathrm{E}+03 \\
1.6 \mathrm{E}+04 \\
9.5 \mathrm{E}+01 \\
5.6 \mathrm{E}+03 \\
6.1 \mathrm{E}+02 \\
1.9 \mathrm{E}+03 \\
4.1 \mathrm{E}+03 \\
2.8 \mathrm{E}+03 \\
1.2 \mathrm{E}+04 \\
4.1 \mathrm{E}-02 \\
1.0 \mathrm{E}+00 \\
3.7 \mathrm{E}+03 \\
1.2 \mathrm{E}+01 \\
2.4 \mathrm{E}+02 \\
1.2 \mathrm{E}+02 \\
4.4 \mathrm{E}+04 \\
0.0 \mathrm{E}+00 \\
4.6 \mathrm{E}+04 \\
5.9 \mathrm{E}-01 \\
2.6 \mathrm{E}+03 \\
4.5 \mathrm{E}+02 \\
3.7 \mathrm{E}+04 \\
1.1 \mathrm{E}+04\end{array}$ \\
\hline USSR & & & & \\
\hline $\begin{array}{l}\text { SFSR }(0.15)(e) \\
\text { Ukraine } \\
\text { Uzbek }(0.2) \\
\text { Kazakh }(0.4) \\
\text { Byelorussia } \\
\text { Azerbaija } \\
\text { Gerogia } \\
\text { Moldevia } \\
\text { Lithuania } \\
\text { Turkmen (0.04) } \\
\text { Latvia } \\
\text { Estonia } \\
\text { Armenia }\end{array}$ & $\begin{array}{l}2.1 \mathrm{E}+07 \\
5.0 \mathrm{E}+07 \\
3.1 \mathrm{E}+06 \\
5.9 \mathrm{E}+06 \\
9.6 \mathrm{E}+06 \\
6.0 \mathrm{E}+06 \\
5.0 \mathrm{E}+06 \\
4.0 \mathrm{E}+06 \\
3.4 \mathrm{E}+06 \\
1.1 \mathrm{E}+05 \\
2.5 \mathrm{E}+06 \\
1.5 \mathrm{E}+06 \\
3.0 \mathrm{E}+06\end{array}$ & $\begin{array}{l}1.1 \mathrm{E}+03 \\
4.2 \mathrm{E}+04 \\
9.5 \mathrm{E}-01 \\
1.4 \mathrm{E}+01 \\
1.5 \mathrm{E}+03 \\
4.0 \mathrm{E}+00 \\
3.4 \mathrm{E}+01 \\
3.2 \mathrm{E}+03 \\
1.2 \mathrm{E}+03 \\
1.7 \mathrm{E}-02 \\
6.4 \mathrm{E}+02 \\
1.3 \mathrm{E}+02 \\
1.6 \mathrm{E}+01\end{array}$ & $\begin{array}{l}1.2 \mathrm{E}+04 \\
2.2 \mathrm{E}+05 \\
4.6 \mathrm{E}+00 \\
9.0 \mathrm{E}+01 \\
1.5 \mathrm{E}+04 \\
1.9 \mathrm{E}+01 \\
1.6 \mathrm{E}+02 \\
1.6 \mathrm{E}+04 \\
1.5 \mathrm{E}+04 \\
8.0 \mathrm{E}-02 \\
8.3 \mathrm{E}+03 \\
2.1 \mathrm{E}+03 \\
7.7 \mathrm{E}+01\end{array}$ & $\begin{array}{l}1.3 \mathrm{E}+04 \\
2.6 \mathrm{E}+05 \\
5.5 \mathrm{E}+00 \\
1.0 \mathrm{E}+02 \\
1.6 \mathrm{E}+04 \\
2.3 \mathrm{E}+01 \\
2.0 \mathrm{E}+02 \\
1.9 \mathrm{E}+04 \\
1.7 \mathrm{E}+04 \\
9.7 \mathrm{E}-02 \\
8.9 \mathrm{E}+03 \\
2.2 \mathrm{E}+03 \\
9.4 \mathrm{E}+01\end{array}$ \\
\hline
\end{tabular}

Collective 70-yr Dose, External Total 
TABLE 5.1. (contd)

\begin{tabular}{|c|c|c|c|c|}
\hline \multirow[b]{2}{*}{ Country } & \multirow[b]{2}{*}{ Population (a) } & \multicolumn{3}{|c|}{$\begin{array}{l}\text { Collective } 70-y r \text { Dose, } \\
\text { Person-Sieverts }\end{array}$} \\
\hline & & Internal & External & Total \\
\hline \multicolumn{5}{|l|}{$\underline{\text { UK }}$} \\
\hline $\begin{array}{l}\text { Engl land } \\
\text { No. Irel and (b) } \\
\text { Scotland } \\
\text { Wales }\end{array}$ & $\begin{array}{l}4.7 E+07 \\
1.5 E+06 \\
5.1 E+06 \\
2.8 E+06\end{array}$ & $\begin{array}{l}2.3 \mathrm{E}+01 \\
3.0 \mathrm{E}-01 \\
1.3 \mathrm{E}+00 \\
3.3 \mathrm{E}-01\end{array}$ & $\begin{array}{l}1.1 \mathrm{E}+02 \\
1.4 \mathrm{E}+00 \\
6.4 \mathrm{E}+00 \\
1.6 \mathrm{E}+00\end{array}$ & $\begin{array}{l}1.3 \mathrm{E}+02 \\
1.7 \mathrm{E}+00 \\
7.7 \mathrm{E}+00 \\
1.9 \mathrm{E}+00\end{array}$ \\
\hline \multicolumn{5}{|l|}{ SUBTOTAL } \\
\hline $\begin{array}{l}\text { Europe } \\
\text { USSR } \\
\text { UK }\end{array}$ & $\begin{array}{l}5.0 E+08 \\
1.1 E+08(f) \\
5.6 E+07\end{array}$ & $\begin{array}{l}3.4 \mathrm{E}+04 \\
4.6 \mathrm{E}+04 \\
2.5 \mathrm{E}+01\end{array}$ & $\begin{array}{l}1.7 E+05 \\
2.9 E+05 \\
1.2 E+02\end{array}$ & $\begin{array}{l}2.0 E+05 \\
3.4 E+05 \\
1.4 E+02\end{array}$ \\
\hline TOTAL & $6.7 E+08(g)$ & $8.3 E+04$ & $4.6 E+05$ & $5.4 \mathrm{E}+05$ \\
\hline
\end{tabular}

(a) From The World Almanac (Hoffman 1986).

(b) Because meteorological data were not available for areas over the ocean, the calculated concentrations in the air and on the ground are incomplete, that is, they are underestimated.

(c) The values for Italy include Corsica, Sardinia and Sicily.

(d) The values for Turkey include Cyprus.

(e) Values in () are the fraction of the land area included in the grid used, and for this study, the fraction of the population within the grid.

(f) The total of the fractional populations of the individual republics covered by the study grid is $1.1 \mathrm{E}+8$, or $42 \%$ of the total population given for the USSR.

(g) The total of the populations in the fractions of the individual countries covered by the study grid.

5600 person-sieverts, nearly double the 2900 person-sieverts for dry deposition only. "Downwind" in France, dose based on dry deposition is nearly double that based on total deposition, 1100 versus 610 person-sieverts. 



\subsection{MODELED DEPOSITION FOR WESTERN AND EASTERN EUROPE}

Knowledge of the total amount of each radionuclide deposited enables the impact of the Chernobyl accident on the environment to be studied. Information on the amount deposited can be obtained through direct measurement at specific locations following the accident or through the application of meteorological models to estimate the amount deposited. Direct measurements are limited in number, in terms of locations and time, but have the advantage of relatively high accuracy. Model-determined deposition amounts have the advantage of providing complete spatial and temporal coverage, but are accompanied by substantial uncertainty.

The purpose of this section is to provide estimates of total deposition for western and eastern Europe using the MLAM model. In particular, cumulative total deposition of cesium-137 and iodine-131 from the time of the accident on April 26 to May 15 is estimated and the resulting spatial pattern is used to display the estimates. Similar estimates and spatial patterns can be determined for all other radionuclides released during the accident. However, their spatial patterns will differ only by a multiplicative constant (directly related to amount released) from the patterns presented for cesium-137 and iodine-131.

Additional information in the section is given to aid in understanding the model-derived estimates. For each total deposition spatial pattern, information on the underlying patterns for wet and dry deposition is given. Comparison of the relative contribution of wet and dry deposition for a region provides one basis for evaluating the impact of uncertainty in precipitation occurrence and wet and dry removal rates. Further insight into the performance of the MLAM model is gained by examining deposition as a function of when the material is released and as a function of when it is deposited. Finally, for the limited number of deposition measurements available, a comparison of observed data with model estimates provides direct information on the relative performance of the model. If model estimates compare reasonably well with known measurements, then similar performance may be expected at locations where deposition amounts are unknown. 


\subsection{MODELED DEPOSITION SPATIAL PATTERN}

Spatial patterns determined from modeled deposition for cesium-137 and iodine-131 provide information on the extent of the Chernobyl reactor accident's impact on the environment. Total deposition of every radionuclide released during the accident is of primary interest. Cesium-137 and iodine-131 are used to display the spatial pattern for all radionuclides. Other depositing radionuclides will have similar patterns because they followed the same transport paths and have deposition characteristics similar to either cesium-137 or iodine-131. Cesium-137 and iodine-131 also contribute significantly to lifetime radiation dose estimates.

Spatial deposition patterns, presented in the form of contour maps for western and eastern Europe, provide information on where material is expected to be deposited. Expanded contour maps that emphasize eastern Europe are given to enable a more detailed examination of the pattern within 1,000 km of Chernobyl. For the purpose of this study, eastern Europe is defined to encompass the area covered by the expanded map, which generally includes the western USSR and eastern European countries. Figure 6.1 gives base maps of these two regions with latitude and longitude lines indicated and selected cities identified. The purpose of the maps is to aid the reader in familiarizing himself with the geographic location of cities and countries on the maps. The maps are based on a polar stereographic projection.

Information on spatial patterns is first presented for cumulative deposition from the time of the accident on April 26 to May 15. The deposition estimates are decay-corrected to $12 Z$ on May 15. Total, wet, and dry deposition spatial patterns for cesium-137 and iodine-131 are given accompanied by descriptions of the relative contribution of wet and dry deposition. Then spatial patterns resulting from three separate release periods are described. Separation of the cumulative total deposition by the three release periods (April 26 002, April 26-April 30, and May 1-5) provides information on the probable transport path of the material and may allow an assessment of the assumptions made about the time pattern for the accident release.

Cumulative deposition for two intermediate periods, April 26 to May 1 and April 26 to May 5, is calculated and displayed spatially for cesium-137 


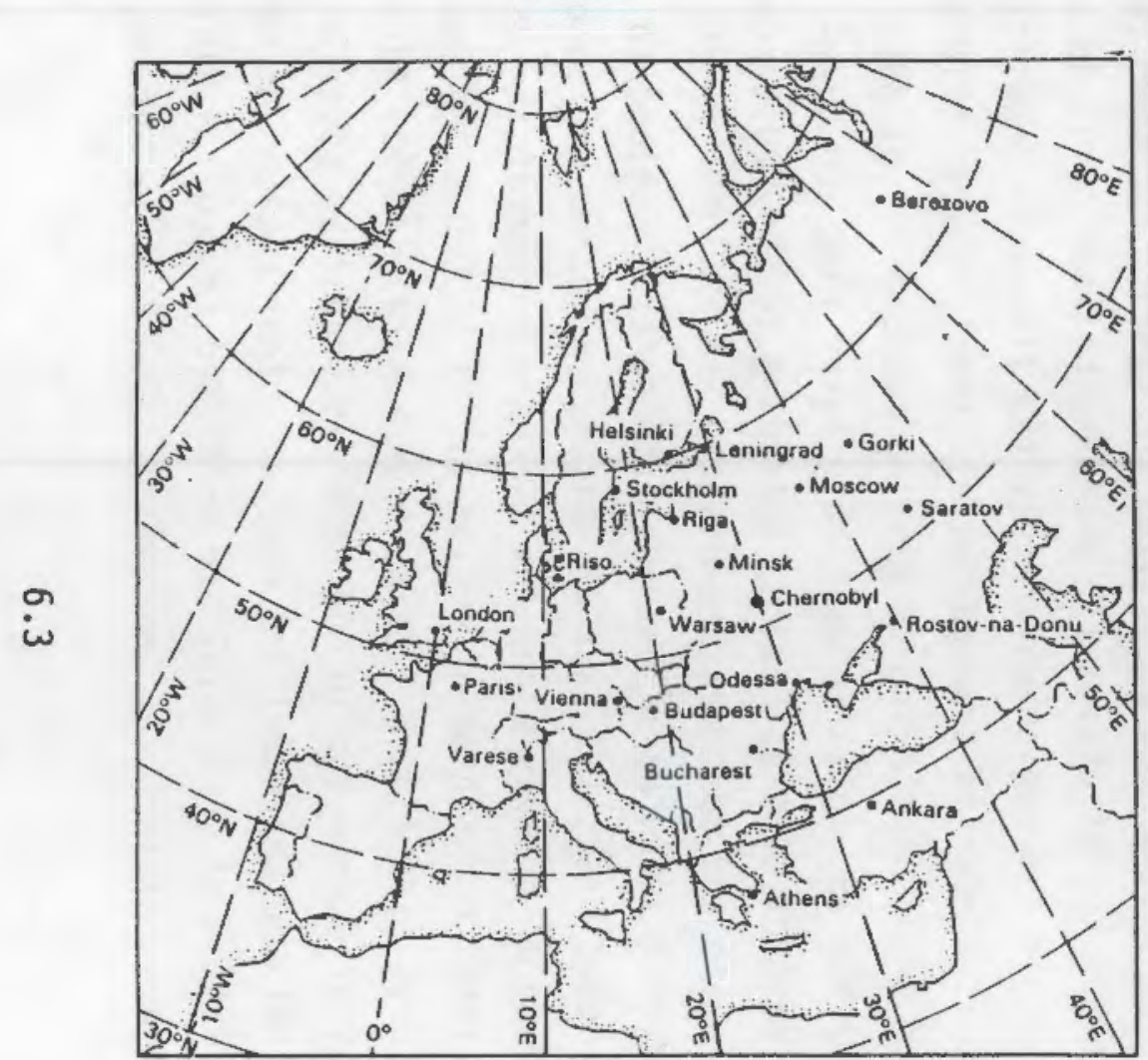

(a)

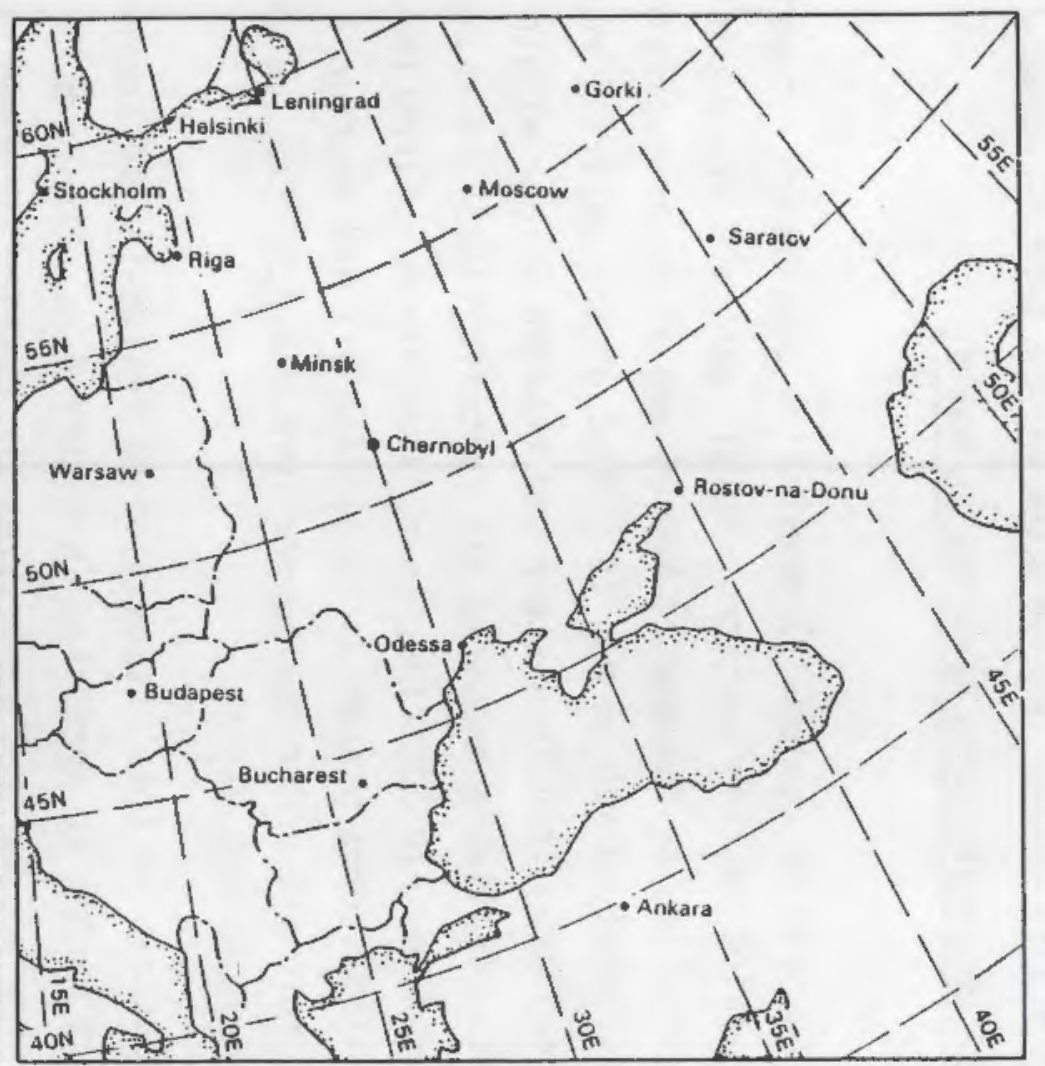

(b)

FIGURE 6.1. Polar Stereographic Projection Maps for (a) Europe and (b) Eastern Europe 
and iodine-131. The intermediate periods provide information on the probable transport paths and give another perspective on the time of release assumptions.

\subsubsection{Cumulative Deposition From April 26 to May 15}

Cesium-137

The spatial pattern of cesium-137 cumulative deposition determined by the MLAM model is presented in this section. Total, wet, and dry deposition is accumulated from the time of release to May 15 and is decay-corrected from the time of the accident to $12 Z$ on May 15 . Most of the material released is assumed to have been deposited in western and eastern Europe within 20 days after the accident. Available measured air concentrations and wet deposition support this assumption. In addition, calculated air concentrations and deposition temporal patterns presented in Section 6.2 and Section 7 substantiate that all material released under the source term characterization exited the model deposition grid before May 15.

The spatial pattern of total deposition of cesium-137 determined for western and eastern Europe is presented in Figure 6.2. Figure $6.2 \mathrm{~b}$ is an expanded view of Figure $6.2 \mathrm{a}$ that emphasizes the eastern European region around Chernobyl. Of the $806 \mathrm{kCi}$ of cesium-137 released between April 26 and May 5 , $60 \%$ is deposited within the region covered by the fine-mesh deposition grid (Figure 4.1). The remainder is transported off the fine mesh grid and is deposited elsewhere or is lost owing to missing meteorological data over the Atlantic Ocean. On May 15, total deposition greater than $100 \mathrm{~Bq} / \mathrm{m}^{2}$ is predicted for all of Europe east of central France, extending to the Mediterranean Sea and Turkey to the south and northern Scandinavia and the USSR to the north. Deposition greater than $1,000 \mathrm{~Bq} / \mathrm{m}^{2}$ extends from central Finland to southern Turkey and from Czechoslovakia to east of Moscow. A second region of deposition greater than $1,000 \mathrm{~Bq} / \mathrm{m}^{2}$ extends along the northern border of the USSR. The maximum predicted total deposition of cesium- 137 is $50,000 \mathrm{~Bq} / \mathrm{m}^{2}$ immediately northwest of Chernobyl (see Figure $6.2 \mathrm{~b}$ ). Approximately $15,000 \mathrm{~Bq} / \mathrm{m}^{2}$ is predicted southeast of Moscow and $10,000 \mathrm{~Bq} / \mathrm{m}^{2}$ is predicted south of Novaya Zemlya island and between Chernobyl and Moscow. Other regions of secondary maximum total deposition of cesium-137 are predicted in central Finland $\left(7,000 \mathrm{~Bq} / \mathrm{m}^{2}\right)$, between Helsinki and Leningrad $\left(7,000 \mathrm{~Bq} / \mathrm{m}^{2}\right)$, between Minsk 


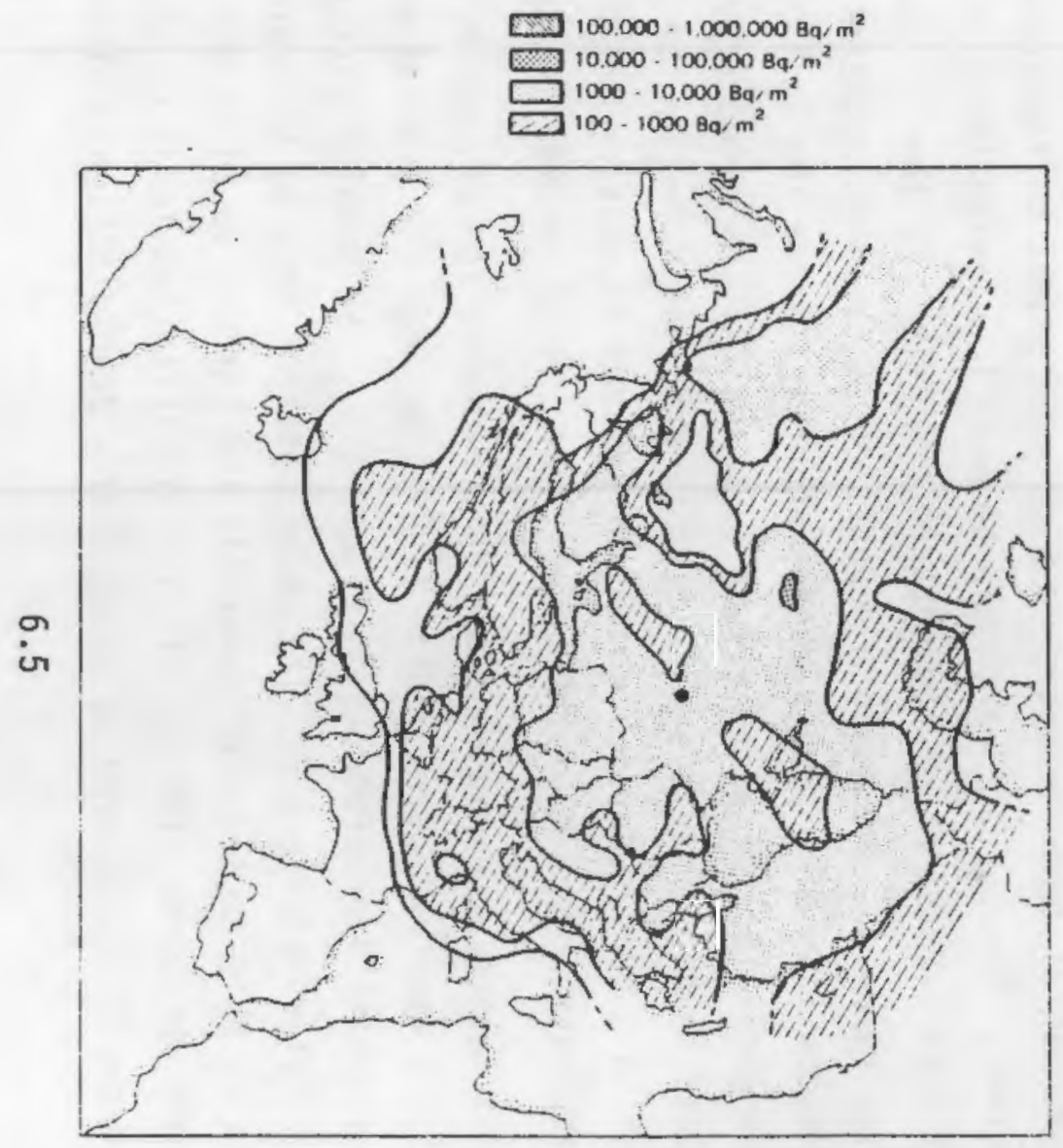

(a)
$100,000 \cdot 1,000,000 \mathrm{Ba} / \mathrm{m}^{2}$

$10.000-100.000 \mathrm{Eg} / \mathrm{m}^{2}$

$\left[1000 \cdot 10.000 \mathrm{~Bq} / \mathrm{m}^{2}\right.$

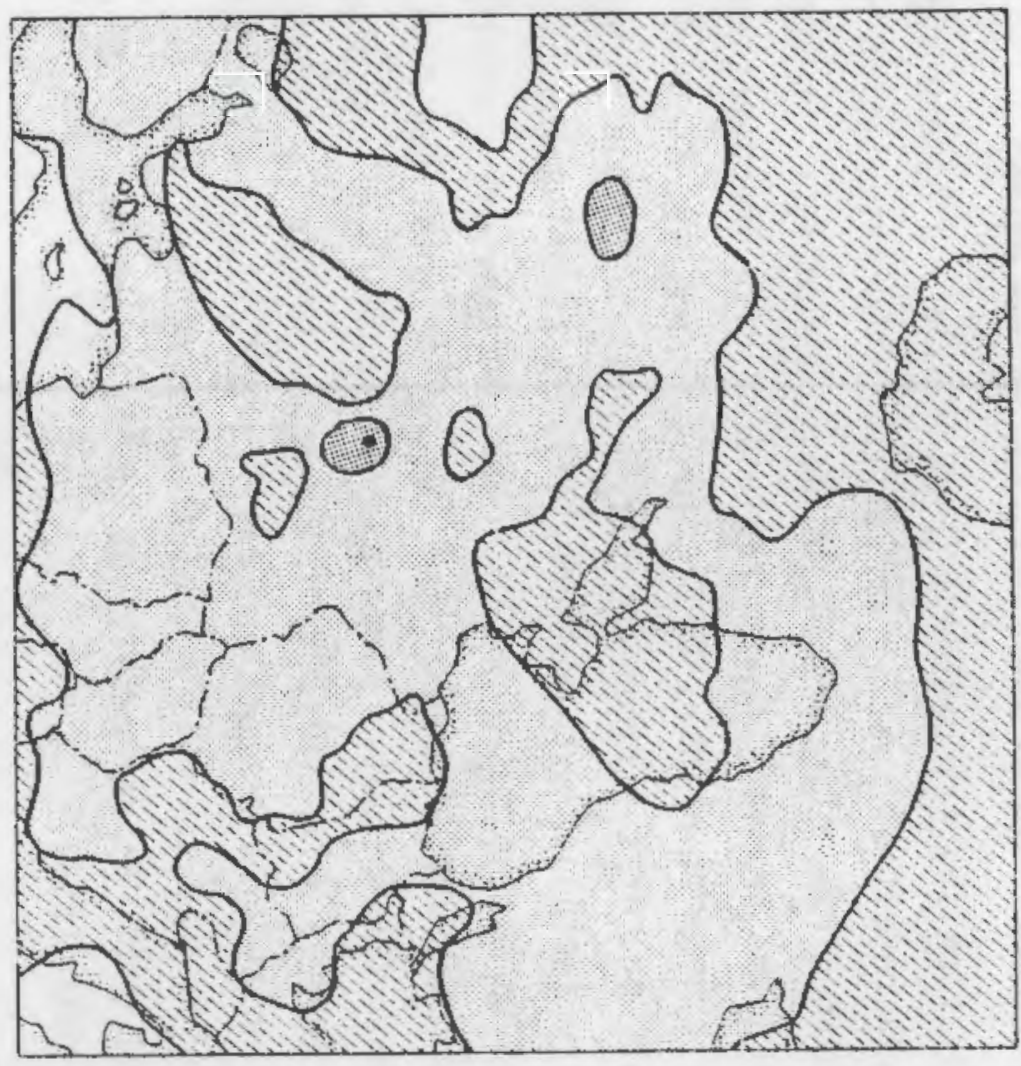

(b)

FIGURE 6.2. Cesium-137 Total Deposition $\left(\mathrm{Bq} / \mathrm{m}^{2}\right)$, Cumulative to May 15, 1986, Spatial Pattern for (a) Europe and (b) Eastern Europe 
and Moscow $\left(5,000 \mathrm{~Bq} / \mathrm{m}^{2}\right)$, in central Czechoslovakia $\left(5,000 \mathrm{~Bq} / \mathrm{m}^{2}\right)$, north of Odessa $\left(4,000 \mathrm{~Bq} / \mathrm{m}^{2}\right)$, and in central Turkey $\left(7,000 \mathrm{~Bq} / \mathrm{m}^{2}\right)$.

Wet deposition spatial patterns (Figure 6.3a and b) are typified by their irregularity, a result of spatial variability of precipitation occurrence and coincidence with plume. Dry deposition patterns reflect the smoother air concentration plume transport, with regions of high dry deposition coinciding with dominant transport paths. In Section 7, xenon-133 is used to illustrate daily transport patterns. Total deposition maxima are due to wet deposition in nearly every instance, with wet deposition accounting for over $70 \%$ of the deposition and in most cases over $90 \%$. Near Odessa, dry deposition dominates, accounting for over $90 \%$ of deposition. Immediately northwest of Chernobyl, $70 \%$ of the deposition is wet. Along the initial path of the plume, dry deposition dominates with over $90 \%$ of the deposition dry, except immediately northwest of Chernobyl and south-central Finland. East and north of Moscow, wet deposition contributes over $95 \%$ of the deposition. Over the entire finemesh deposition grid, approximately $70 \%$ of the total deposition of cesium-137 is due to wet deposition.

Wet deposition is reflected in the total deposition pattern mainly through secondary maximum total deposition and is highly dependent on the input precipitation pattern. Hence, caution should be used in viewing these maximum areas of deposition. Portions of the pattern are driven by the wet deposition from the initial release. The maximum deposition south of Novaya Zemlya and southeast of Moscow is due to precipitation occurring after the initial release plume was scavenged in Scandinavia (Figure 6.3a and b). As noted previously, deposition values in Scandinavia are felt to be underestimated by the use of 24-h precipitation. Consequently, "downwind" maximum deposition areas are probably overestimated because of the underestimation of removal in Scandinavia.

Finland and Sweden produced maps of surface deposition of cesium-137 based on available measured data. Smith (1987) included the spatial pattern for Scandinavia, which is reproduced as Figure 6.4. The modeled pattern that is comparable is given Figure 6.2. The model patterns tend to underpredict measured values in this region, and generally the pattern based on measured data extends more westward. The use of 24-h precipitation leads to underestimation of deposition compared to using hourly precipitation. Since the 

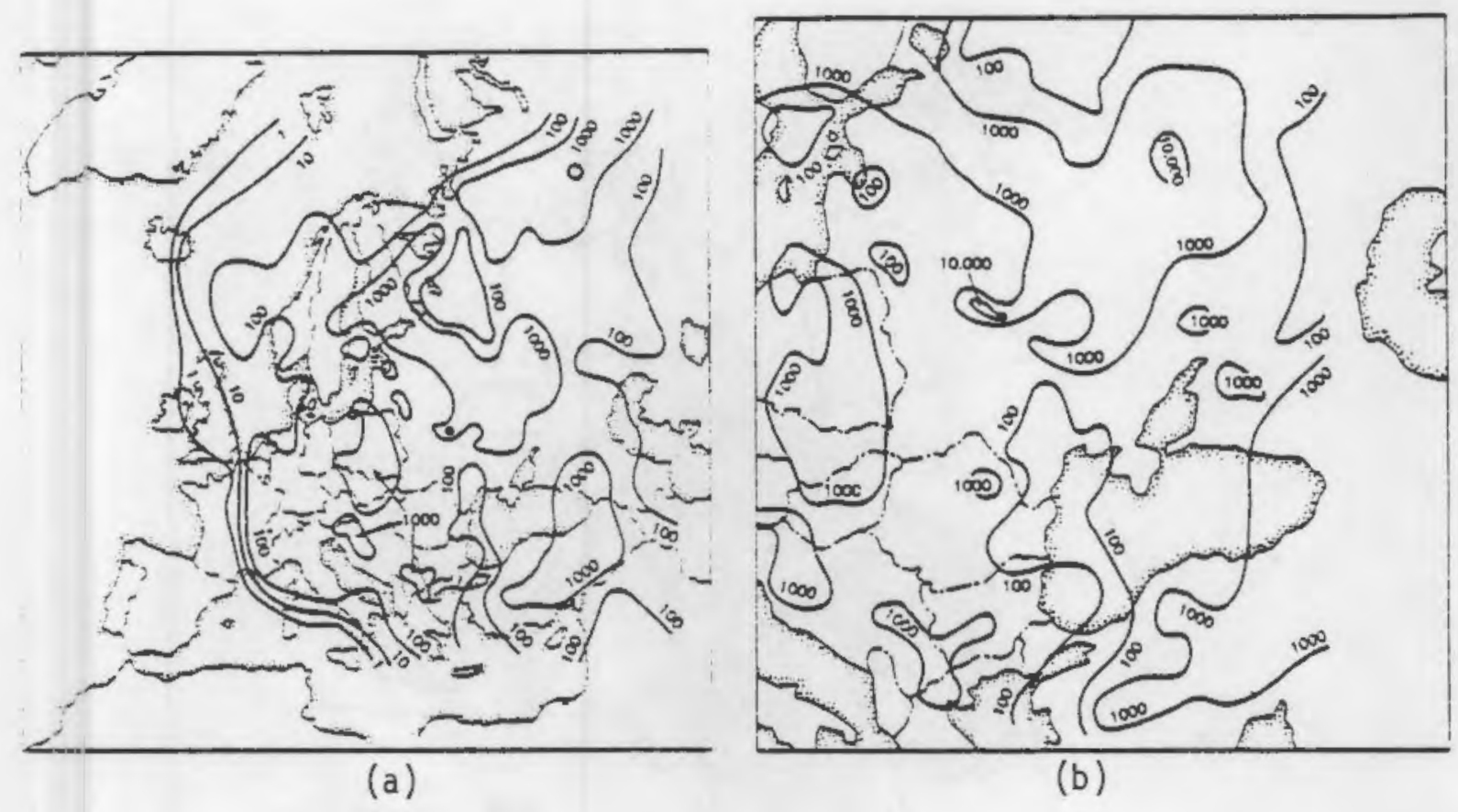

(b)
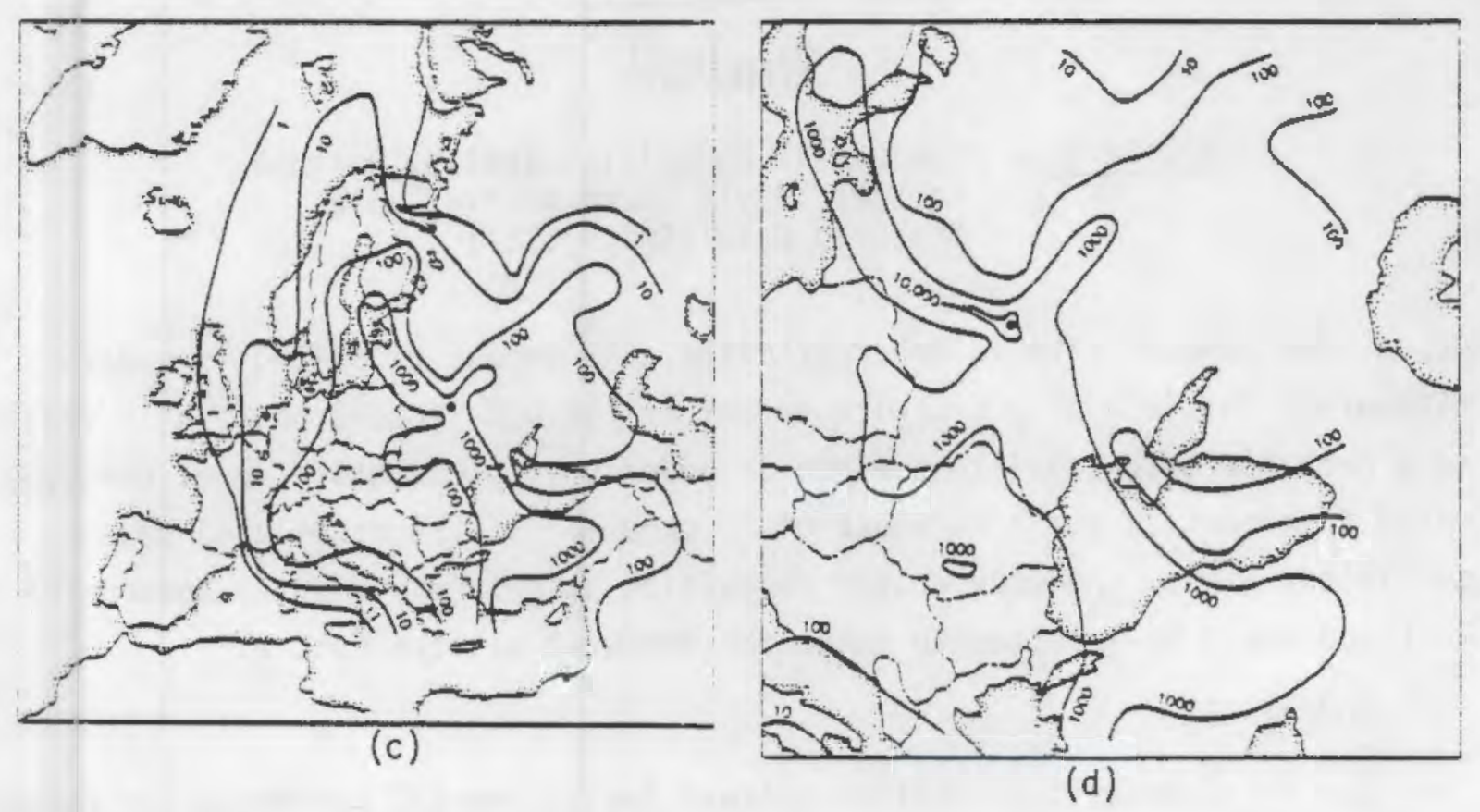

FIGURE 6.3. Cesium-137 Wet $(\mathrm{a}, \mathrm{b})$ and Dry $(\mathrm{c}, \mathrm{d})$ Deposition $\left(\mathrm{Bq} / \mathrm{m}^{2}\right)$, Cumulative to May 15, 1986, Spatial Patterns for Europe and Eastern Europe 


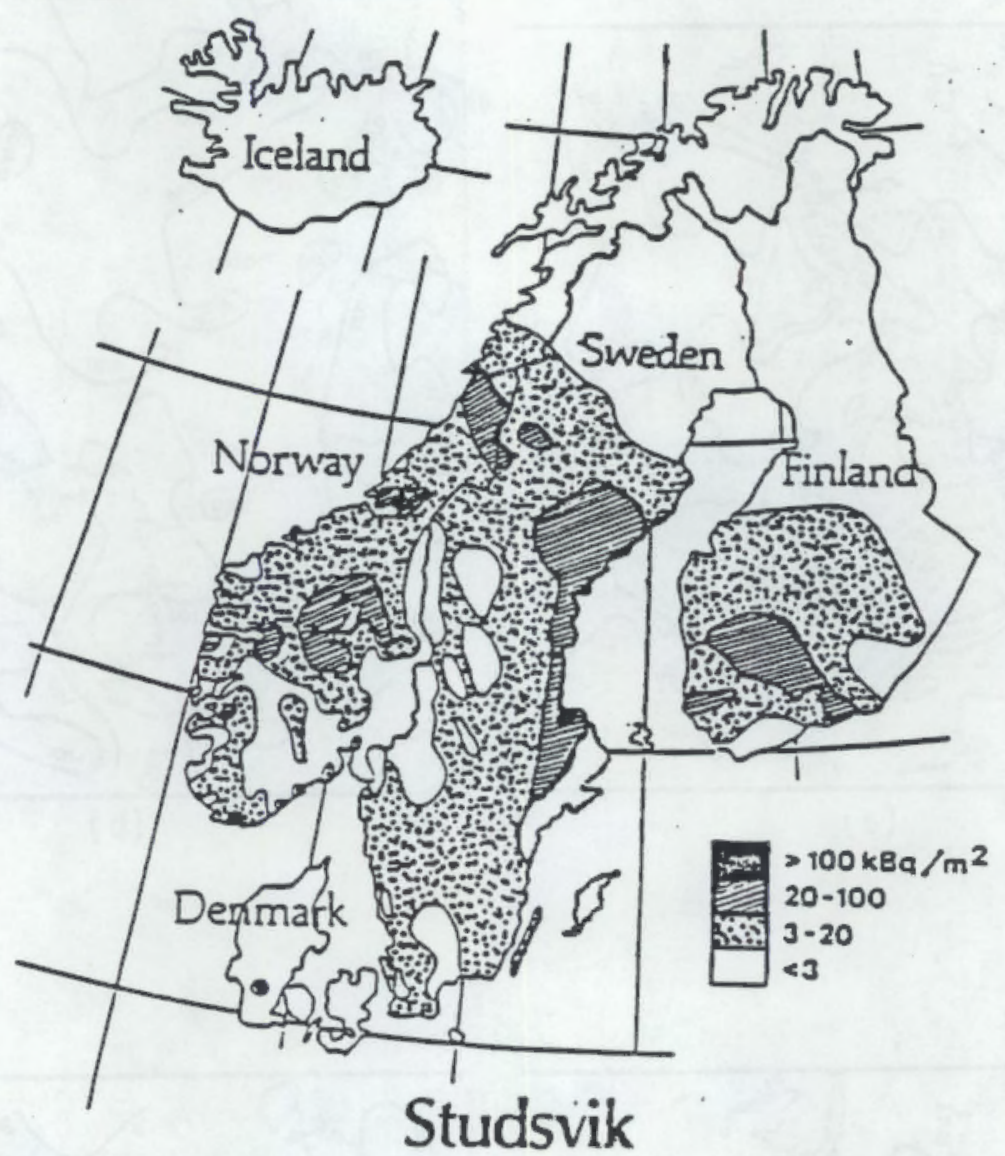

FIGURE 6.4. Cesium-137 Deposition Spatial Pattern in Scandinavia Based on Available Measured Data (Smith 1987)

deposition removal rate is underestimated, the amount deposited is underestimated. The lack of a westward extent of the model-based pattern is related to a need for mass-consistent winds in order to appropriately model the complicated transport in the area south of Stockholm. If the model used massconsistent winds, the model-based deposition pattern would shift toward the west and would be expected to match the measured pattern better.

\section{Iodine-131}

The total deposition spatial pattern for iodine-131 estimated for Europe and eastern Europe (Figure 6.5) has several features that are similar to the spatial pattern for cesium-137. Of the $16.4 \mathrm{MCi}$ of iodine-131 released between April 26 and May 5, 60\% is deposited within the region covered by the fine-mesh 


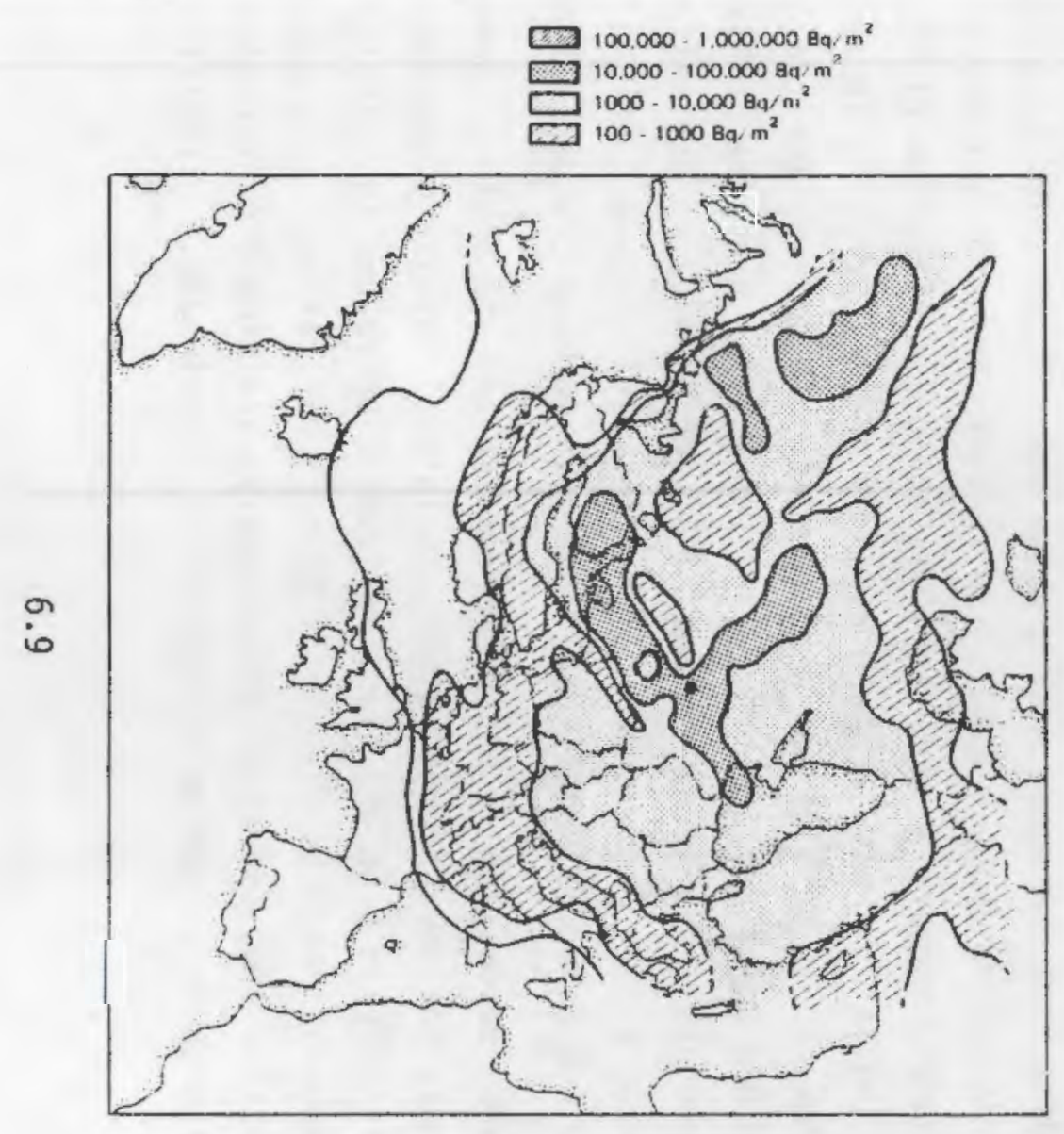

(a)
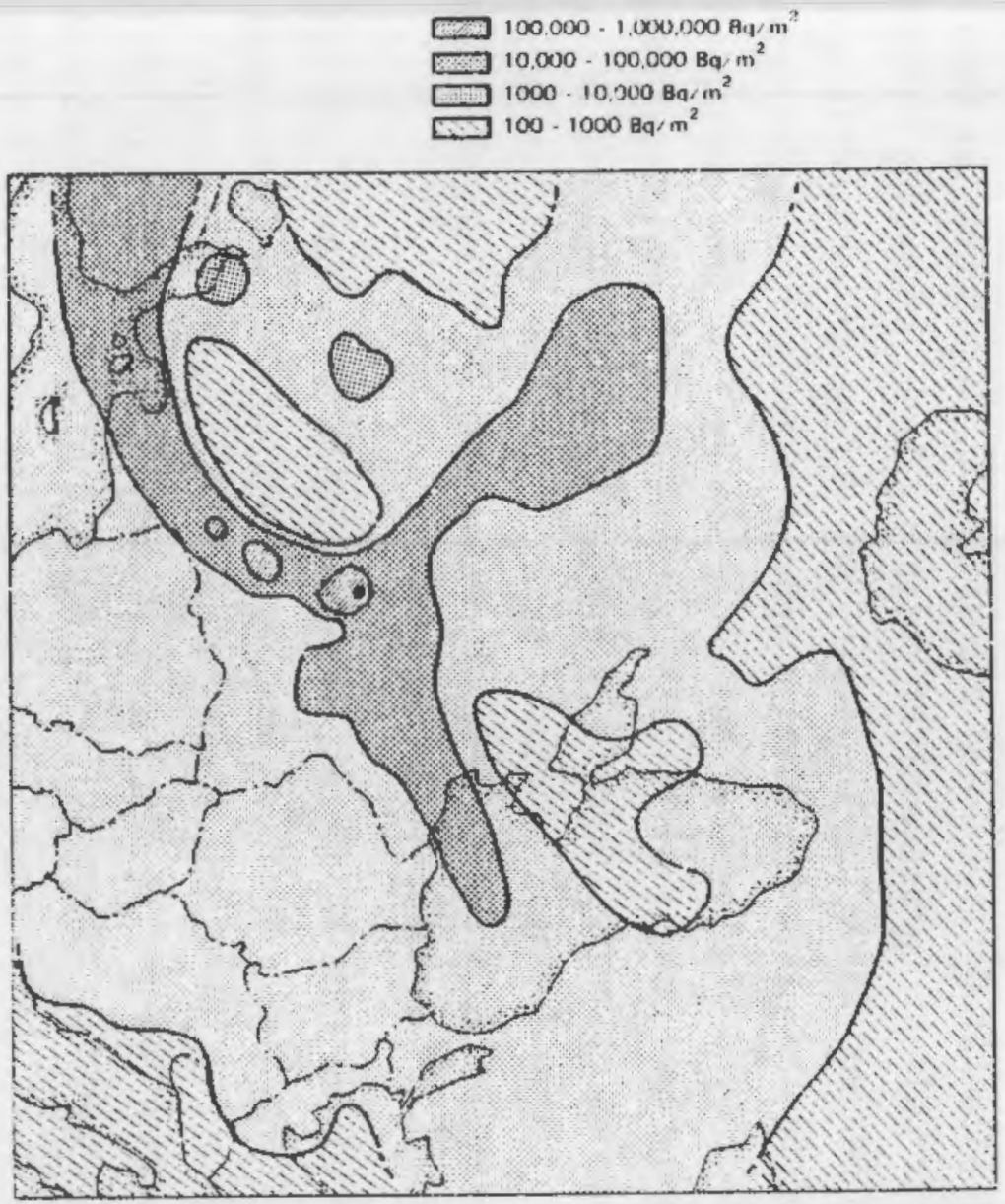

(b)

FIGURE 6.5. Iodine-131 Total Deposition $\left(\mathrm{Bq} / \mathrm{m}^{2}\right)$, Cumulative to May 15, 1986, Spatial Pattern for (a) Europe and (b) Eastern Europe 
deposition grid (Figure 4.1). The remainder is transported off the fine-mesh grid and is deposited elsewhere or is lost owing to missing meteorological data over the Atlantic Ocean. Total deposition on May 15 greater than $100 \mathrm{~Bq} / \mathrm{m}^{2}$ is estimated for all of Europe east of eastern France, extending to the Mediterranean Sea and Turkey to the south, and northern Scandinavia and the USSR to the north and east. Deposition greater than $100,000 \mathrm{~Bq} / \mathrm{m}^{2}$ occurs immediately northwest of Chernobyl and along the initial transport path between Minsk and the eastern border of Poland. A three-pronged region extending from Chernobyl has estimated deposition greater than $10,000 \mathrm{~Bq} / \mathrm{m}^{2}$, with each prong resulting from dominant transport paths during the accident release. South of Novaya Zemlya, a second region greater than $10,000 \mathrm{~Bq} / \mathrm{m}^{2}$ is estimated and is the result of wet deposition.

Over the entire fine-mesh grid, wet deposition contributes approximately $50 \%$ of total deposition. Greatest amounts of wet deposition occur east and north of Chernobyl (Figure 6.6) where it contributes over $90 \%$ of total deposition. A maximum iodine-131 total deposition of $650,000 \mathrm{~Bq} / \mathrm{m}^{2}$ is estimated immediately northwest of Chernoby1. Wet deposition accounts for $25 \%$ of the total deposition at the maximum (Figure 6.6). The northwestern and southern prongs extending from Chernobyl with greater than $10,000 \mathrm{~Bq} / \mathrm{m}^{2}$ total deposition are $100 \%$ dry deposited (Figure 6.6d). In southern Finland, wet deposition assumes dominance, varying from 50 to $100 \%$, and a local maximum of $35,000 \mathrm{~Bq} / \mathrm{m}^{2}$ total deposition is $75 \%$ wet. Between Helsinki and Leningrad, a local maximum of $20,000 \mathrm{~Bq} / \mathrm{m}^{2}$ is essentially all wet deposition; similarly for the local maximum of $15,000 \mathrm{~Bq} / \mathrm{m}^{2}$ between Moscow and Leningrad. Near the $0 \mathrm{~b}$ River, wet deposition accounts for a local maximum of $35,000 \mathrm{~Bq} / \mathrm{m}^{2}$. At the eastern tip of the dry deposition prong extending from Chernobyl (Figure 6.6d), a local maximum of $40,000 \mathrm{~Bq} / \mathrm{m}^{2}$ is equally split between wet and dry deposition.

The maximum deposition in south-central Finland and south of Novaya Zemlya is due to precipitation occurring after the initial release plume was scavenged in Scandinavia (Figure 6.6a and b). The deposition values in Scandinavia are felt to be underestimated by the use of 24-h precipitation. Consequently, maximum deposition areas south of Novaya Zemlya are probably overestimated as a result of the underestimation of removal in Scandinavia. Deposition patterns 

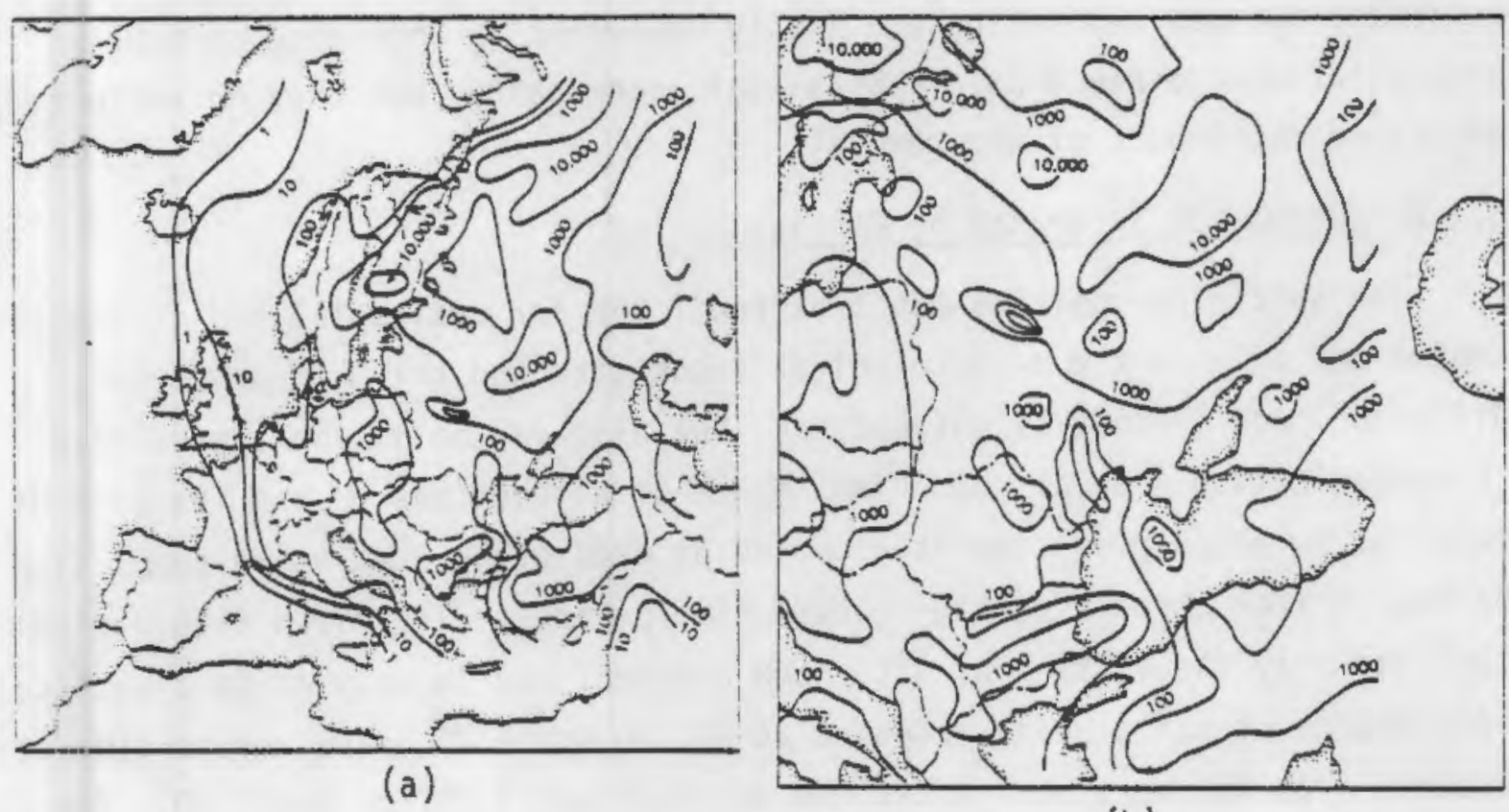

(b)
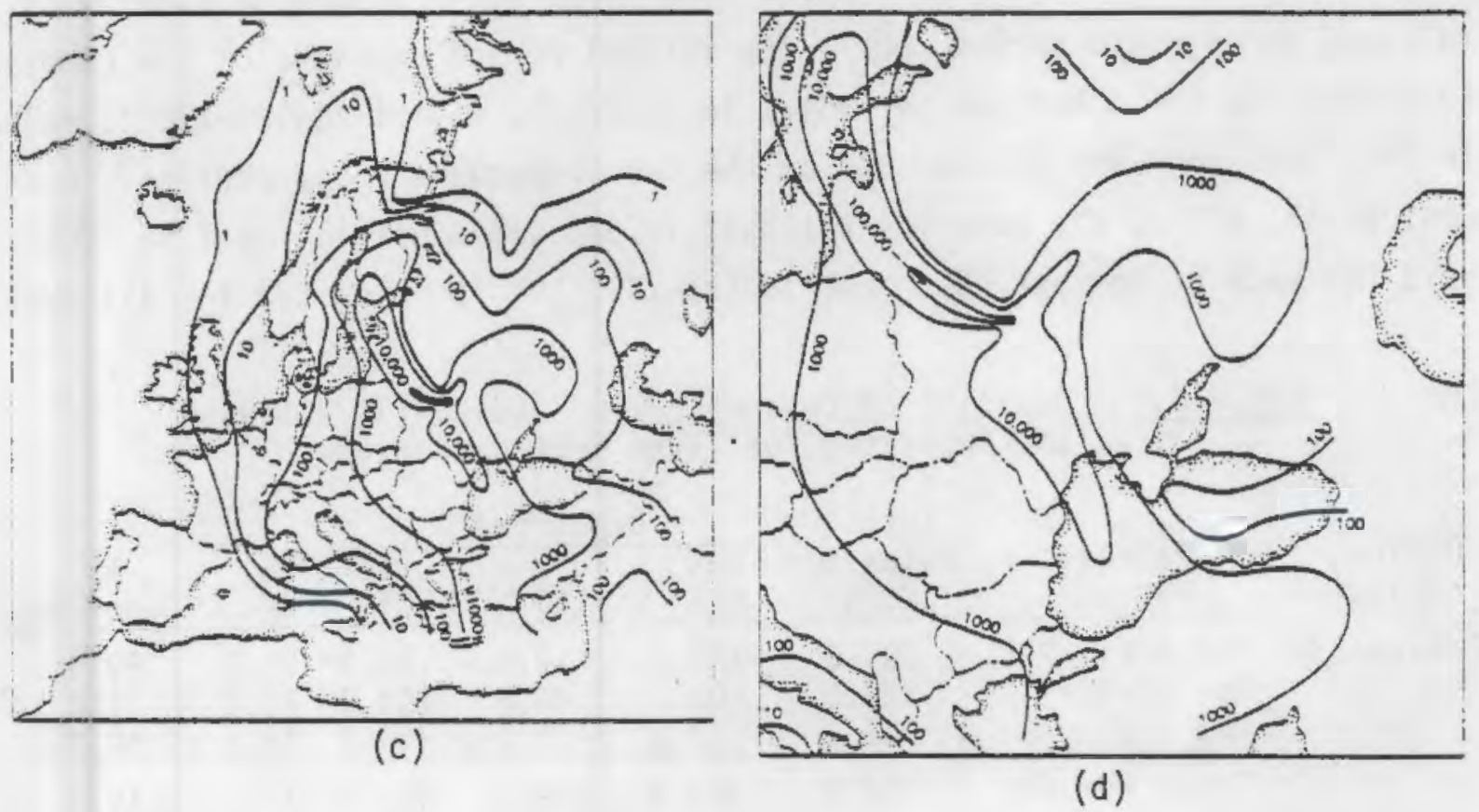

FIGURE 6.6. Iodine-131 Wet $(\mathrm{a}, \mathrm{b})$ and Dry $(\mathrm{c}, \mathrm{d})$ Deposition $\left(\mathrm{Bq} / \mathrm{m}^{2}\right)$, Cumulative to May 15, 1986, Spatial Patterns for Europe and Eastern Europe 
estimated for wet deposition are highly dependent on knowledge of hourly precipitation and hence have substantial uncertainty, but they do reflect generally the impact of wet removal.

\subsubsection{Cesium-137 Separated by Release Period}

The spatial deposition patterns predicted for cesium-137 and iodine-131 depend not only on the meteorological input data and the MLAM transport, diffusion, and deposition assumptions, but also depend on the source term characterization assumptions. The impact of assumptions on the fraction of material released over time is examined by predicting cumulative deposition on May 15 from three separate release time periods. The first time period includes only the first hour after the accident and is modeled by a vertical line source of puffs being released at 002 on April 26. The second time period extends from the next hour after the accident until. 232 on April 30. The third time period covers the 5 days from May 1 to May 5 .

The quantity of cesium-137 and iodine-131 released during each release period is given in Table 6.1. Approximately one-third of the cesium-137 is released during each period, where the initial period consists of $1 \mathrm{~h}$ compared to 5 days for the other two periods. In contrast, $65 \%$ of iodine- 131 is released in the first hour and $17 \%$ in each of the two subsequent 5-day periods. For cesium-137, $60 \%$ of the material released is deposited within the fine-mesh grid for each of the periods. For iodine-131, 50\% is deposited for all three

\section{TABLE 6.1. Quantity of Cesium-137 and Iodine-131 Released} and Deposited for Three Release Periods

\begin{tabular}{|c|c|c|c|c|c|c|c|}
\hline \multirow[b]{2}{*}{$\begin{array}{l}\text { Radio- } \\
\text { nuclide }\end{array}$} & \multirow[b]{2}{*}{$\begin{array}{l}\text { Release } \\
\text { Period }\end{array}$} & \multirow{2}{*}{$\begin{array}{l}\text { Total } \\
\text { Released } \\
\mathrm{kCi} / \mathrm{h} \\
\end{array}$} & \multicolumn{3}{|c|}{ Deposited } & \multirow[b]{2}{*}{$\begin{array}{l}\% \\
\text { Wet } \\
\end{array}$} & \multirow[b]{2}{*}{$\begin{array}{c}\% \\
\text { Depositec }\end{array}$} \\
\hline & & & $\begin{array}{l}\text { Wet } \\
\mathrm{kCi}\end{array}$ & $\begin{array}{l}\text { Dry } \\
\mathrm{kCi} \\
\end{array}$ & $\begin{array}{l}\text { Total } \\
\mathrm{kCi} \\
\end{array}$ & & \\
\hline \multirow[t]{2}{*}{ Cesium-137 } & 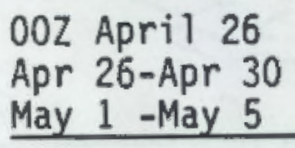 & $\begin{array}{l}297.6 \\
253.1 \\
255.3 \\
\end{array}$ & $\begin{array}{r}160.8 \\
109.8 \\
72.8 \\
\end{array}$ & $\begin{array}{l}17.4 \\
44.5 \\
77.1 \\
\end{array}$ & $\begin{array}{l}178.2 \\
154.3 \\
149.9 \\
\end{array}$ & $\begin{array}{l}90.2 \\
71.2 \\
48.6 \\
\end{array}$ & $\begin{array}{l}59.9 \\
61.0 \\
58.7 \\
\end{array}$ \\
\hline & Total Period & 806.0 & 343.4 & 139.0 & 482.4 & 71.2 & 59.9 \\
\hline \multirow[t]{2}{*}{ Iodine-131 } & $\begin{array}{l}\text { 00Z April } 26 \\
\text { Apr 26-Apr30 } \\
\text { May } 1 \text {-May } 5 \\
\end{array}$ & $\begin{array}{r}10660.0 \\
2858.0 \\
2882.0 \\
\end{array}$ & $\begin{array}{r}3802.4 \\
663.1 \\
354.3 \\
\end{array}$ & $\begin{array}{r}1597.9 \\
794.7 \\
1143.7 \\
\end{array}$ & $\begin{array}{l}5400.3 \\
1457.8 \\
1498.0 \\
\end{array}$ & $\begin{array}{l}70.4 \\
45.5 \\
23.6 \\
\end{array}$ & $\begin{array}{l}50.7 \\
51.0 \\
52.0 \\
\end{array}$ \\
\hline & Total Period & 16400.0 & 4819.8 & 3536.3 & 8356.1 & 57.7 & 51.0 \\
\hline
\end{tabular}


periods. Wet deposition accounts for 90,71 , and $49 \%$ of total cesium- 137 deposition for the three periods, respectively, and for $71 \%$ overall. For iodine-131, the corresponding amounts are 70,46 , and $24 \%$ and $58 \%$ overall.

Initial Release First Hour

The initial release is defined as the first hour after the accident occurred on April 26, 1986 at 01:23 a.m. LST. This period is modeled by MLAM by releasing a vertical line source of material at $00 Z$ on April 26 . Five release points are used for the vertical line source: 300,750, 1250, 1750, and $2250 \mathrm{~m}$. Incorporation of a vertical line source and subsequent redistribution enables the MLAM model to handle the complicated meteorological conditions that the initial release encountered.

In Figure 6.7, the spatial pattern of cesium-137 total deposition on May 15 resulting from the initial release is presented for Europe and expanded for eastern Europe. The deposition is cumulative from time of release to May 15 and is decay-corrected to 122 on May 15. Initially, material is deposited west-northwest of Chernobyl and continues northwest to southern Finland. Subsequently, material is transported east-northeast to southeast. The deposition pattern shows high deposition regions along the main transport path from Chernobyl to southern Finland continuing on to the east-northeast, from Leningrad toward Moscow, and southeast of Moscow. No deposition is predicted for countries west of the USSR.

Predicted maximum total deposition of cesium-137 is approximately $32,000 \mathrm{~Bq} / \mathrm{m}^{2}$ within a few hundred kilometers of Chernobyl. Approximately half of the deposition is wet deposition. Over southern Finland, total depositions up to 4,000 to $5,000 \mathrm{~Bq} / \mathrm{m}^{2}$ are predicted. Where precipitation occurred, approximately $75 \%$ of the deposition is in the form of wet deposition. Dry deposition is predicted to range from $3,000 \mathrm{~Bq} / \mathrm{m}^{2}$ at the southern tip of Finland down to $1,000 \mathrm{~Bq} / \mathrm{m}^{2}$ in south-central Finland. Southeast of Leningrad, 3,000 to $4,000 \mathrm{~Bq} / \mathrm{m}^{2}$ total deposition is predicted with essentially all being due to wet deposition. Similarly, southeast of Moscow, 6,000 to $7,000 \mathrm{~Bq} / \mathrm{m}^{2}$ total deposition in the form of wet deposition is predicted. Examination of trajectory paths indicates the material is transported above $2000 \mathrm{~m}$ and is deposited at the surface when it encounters precipitation. 


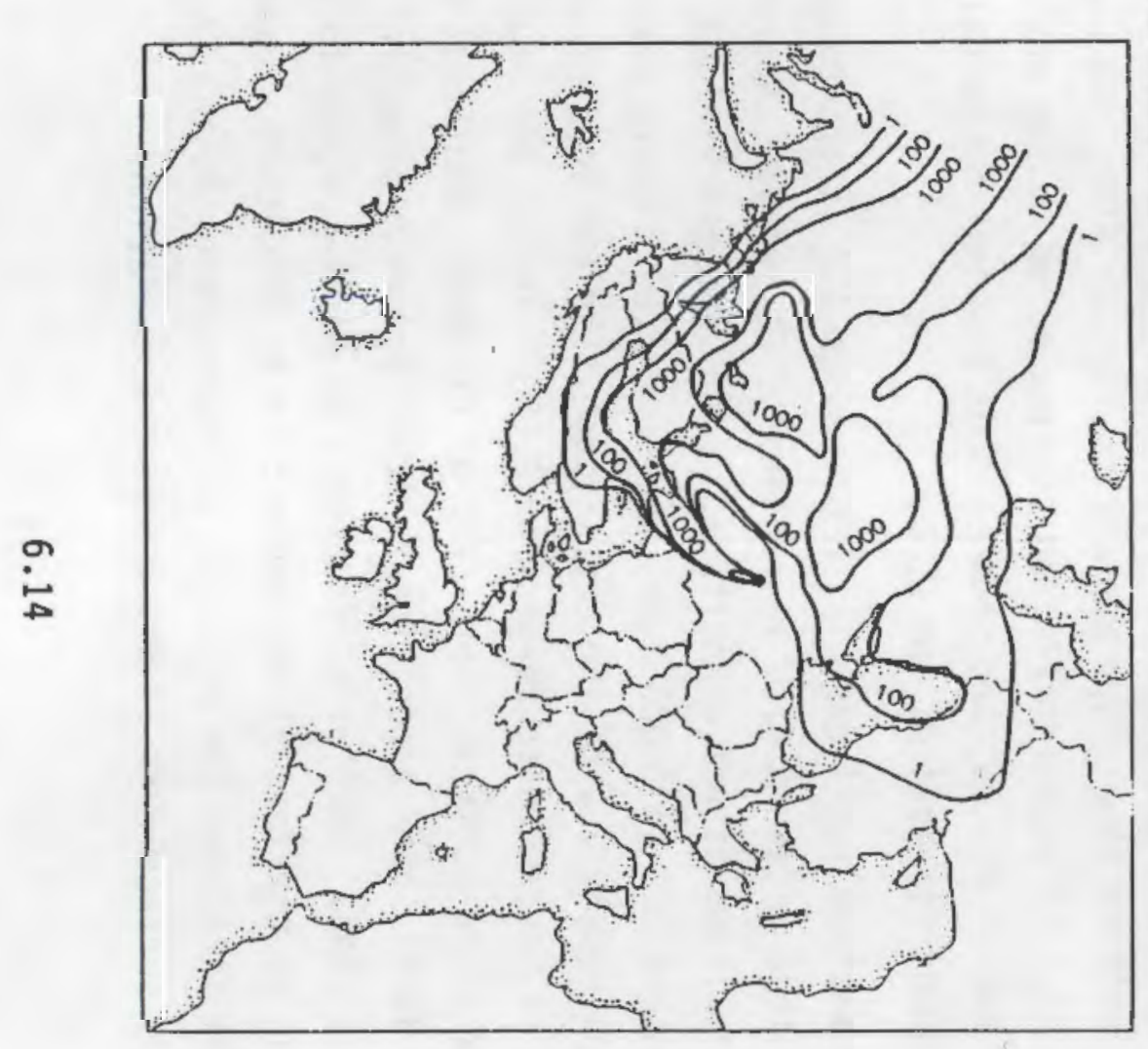

(a)

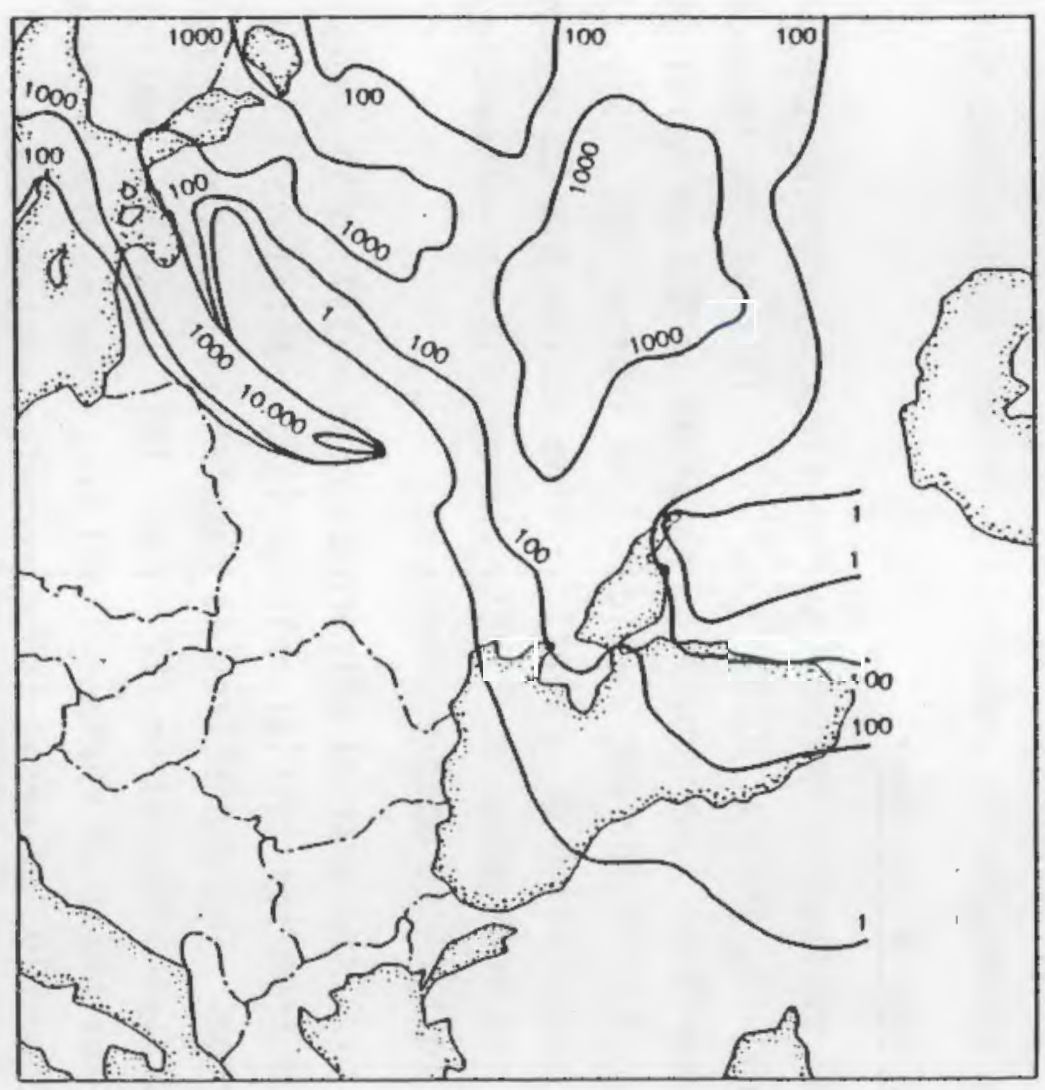

(b)

FIGURE 6.7. Cesium-137 Total Deposition $\left(\mathrm{Bq} / \mathrm{m}^{2}\right)$, Cumulative to May 15, 1986, Spatial Pattern from Initial Release at $00 Z$ on April 26, 1986, for (a) Europe and (b) Eastern Europe 


\section{April 26 to April 30 Release}

After the initial release during the first hour, a different release rate and release height are assumed. The spatial pattern of total deposition of cesium-137 in the 5-day release period, April 26 to April 30, is presented in Figure 6.8. The deposition is cumulative from the time of release to May 15 and is decay-corrected from the time of the accident to $12 Z$ on May 15.

Total deposition of cesium-137 exceeds $100 \mathrm{~Bq} / \mathrm{m}^{2}$ over most of Europe, east of central France and south of central Sweden and Finland. Predicted depositions greater than $1,000 \mathrm{~Bq} / \mathrm{m}^{2}$ occur around Chernobyl extending to the northeast just south of Moscow, across south central Finland, northeast of the Black Sea, and northwestern Italy. Small areas in eastern Europe are predicted to have total depositions below $100 \mathrm{~Bq} / \mathrm{m}^{2}$. These are coincident with areas not directly under the material transport path and no precipitation occurrence. A maximum deposition of $35,000 \mathrm{~Bq} / \mathrm{m}^{2}$ is predicted near Chernobyl, with deposition split approximately equal between wet and dry deposition. A second maximum of $10,000 \mathrm{~Bq} / \mathrm{m}^{2}$ occurs northeast of Chernobyl, approximately halfway to Moscow and is predominantly wet deposition. Extending northwest of Chernobyl, dry deposition accounts for most of the deposition. Other regions with depositions greater than $1,000 \mathrm{~Bq} / \mathrm{m}^{2}$ have predicted maximums of 2,000 to $3,000 \mathrm{~Bq} / \mathrm{m}^{2}$. Deposition in these regions is essentially all wet deposition.

Based on limited trajectory path analysis, it appears that deposition north and northwest of Chernobyl is related to release times during the early part of the 5-day release period, i.e., April 26 and April 27. Deposition in Western Europe has contributions from most release days. To the northeast and southeast, wet deposition is related to material released on April 26 and dry deposition is related to later release times when the transport path switched toward that direction.

\section{May 1 to May 5 Release}

The total deposition spatial pattern of material released on May 1 to May 5 differs from the two previous release periods. In Figure 6.9, the spatial pattern for cesium-137 total deposition is given for releases from May 1 to May 5. Deposition is cumulative from time of release to May 15 and is decaycorrected from the time of the accident to 122 on May 15. 


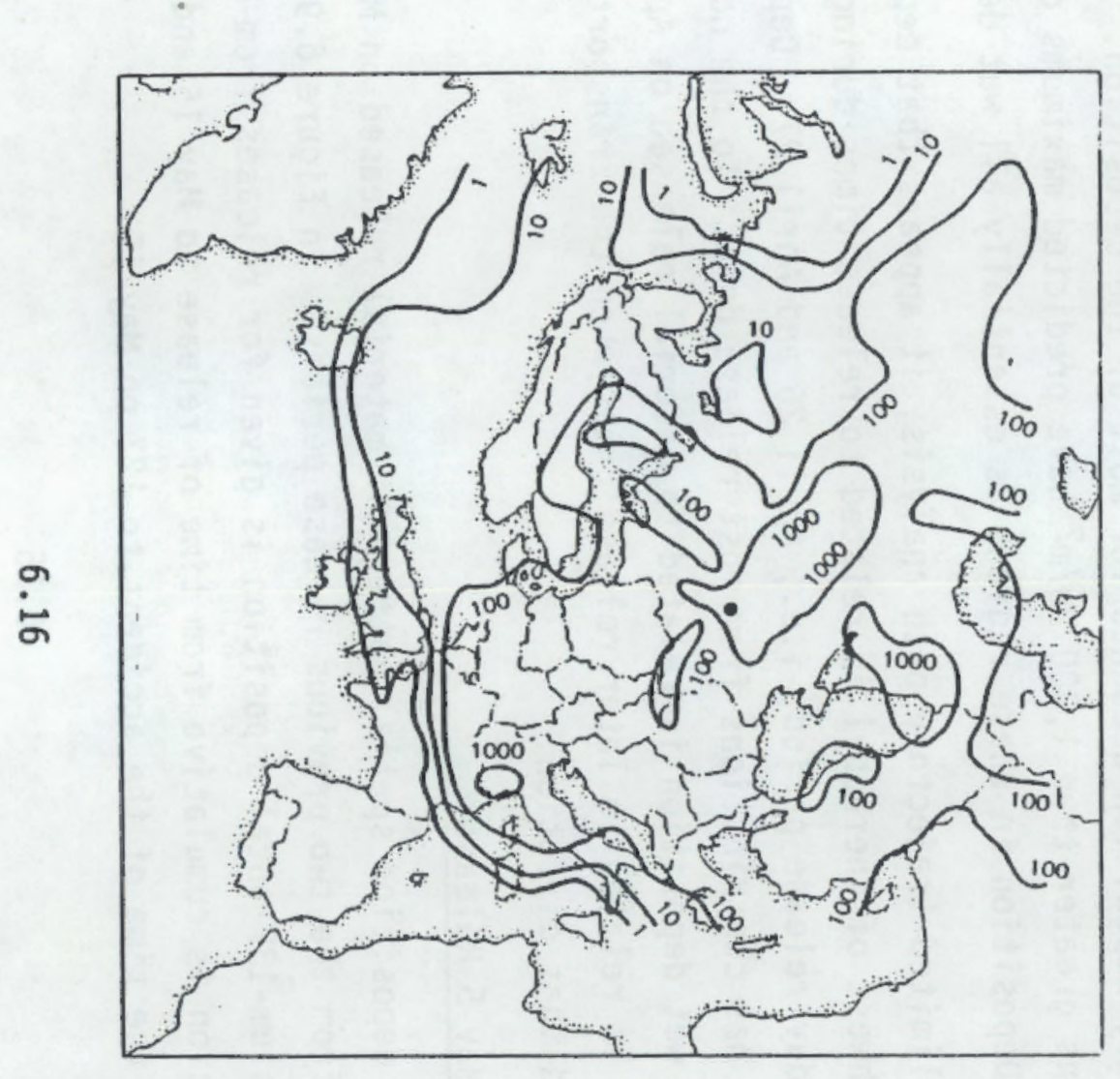

(a)

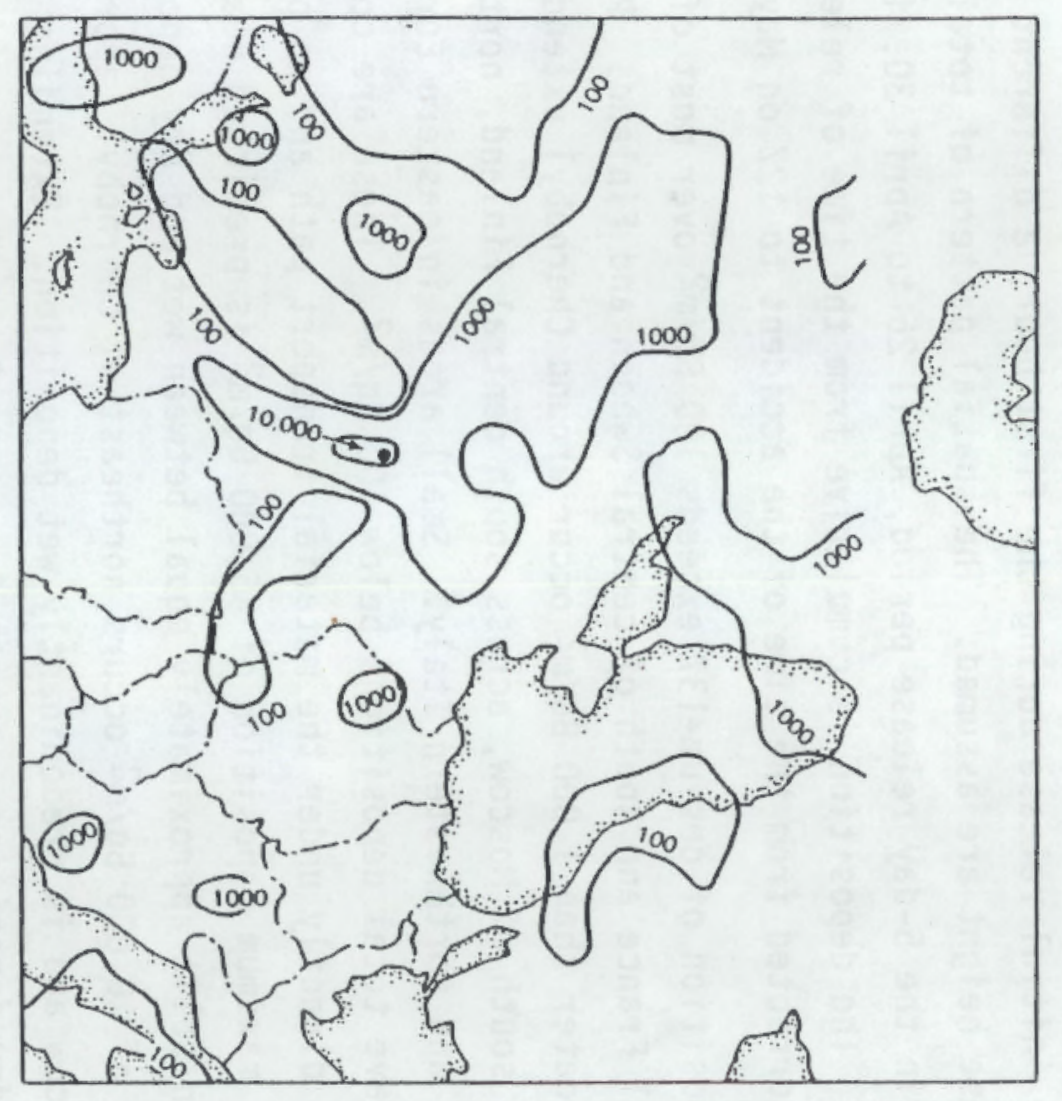

(b)

FIGURE 6.8. Cesium-137 Total Deposition (Bq/m²), Cumulative to May 15, 1986, Spatial Pattern from April 26 to April 30 Release for (a) Europe and (b) Eastern Europe 


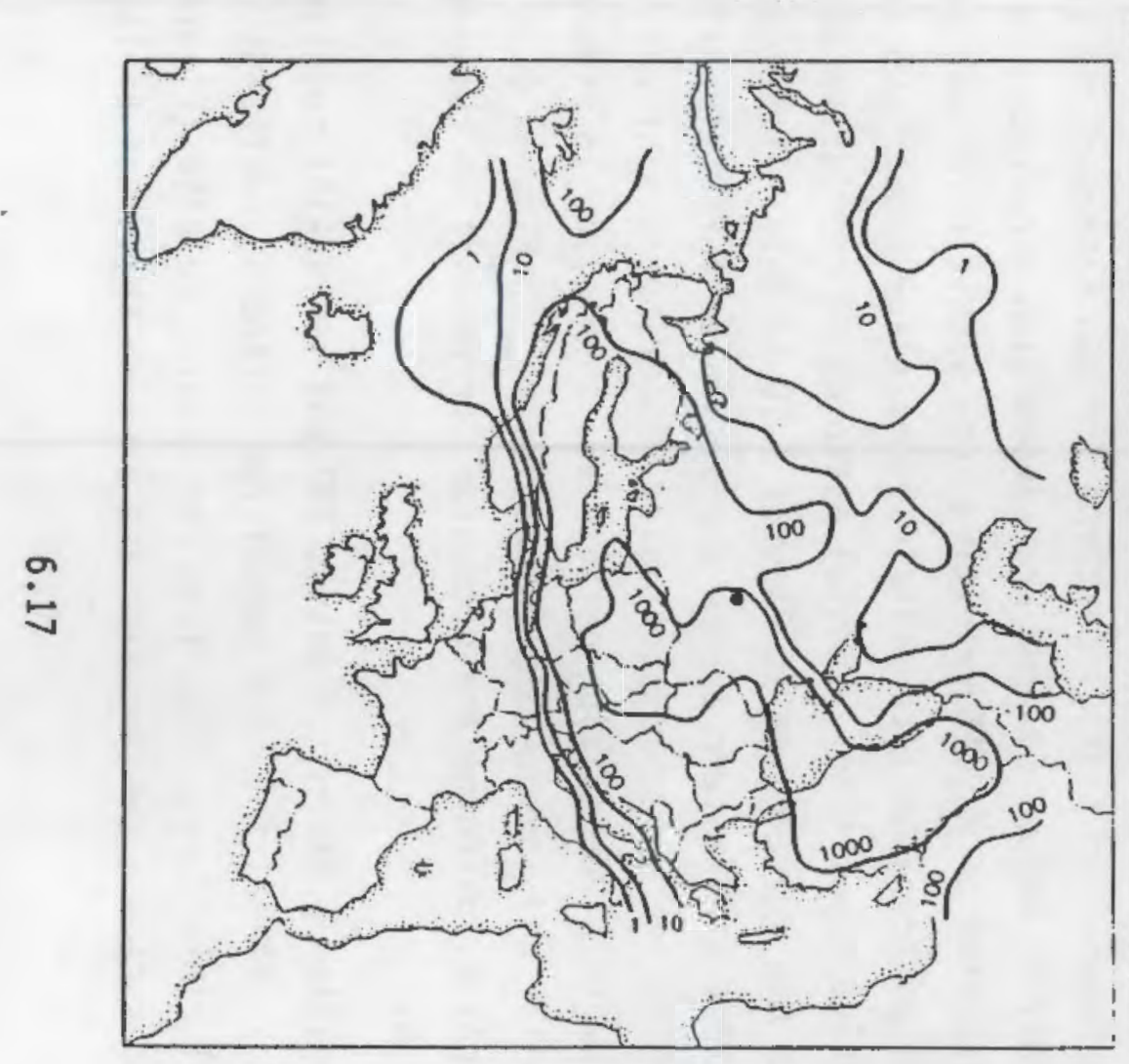

(a)

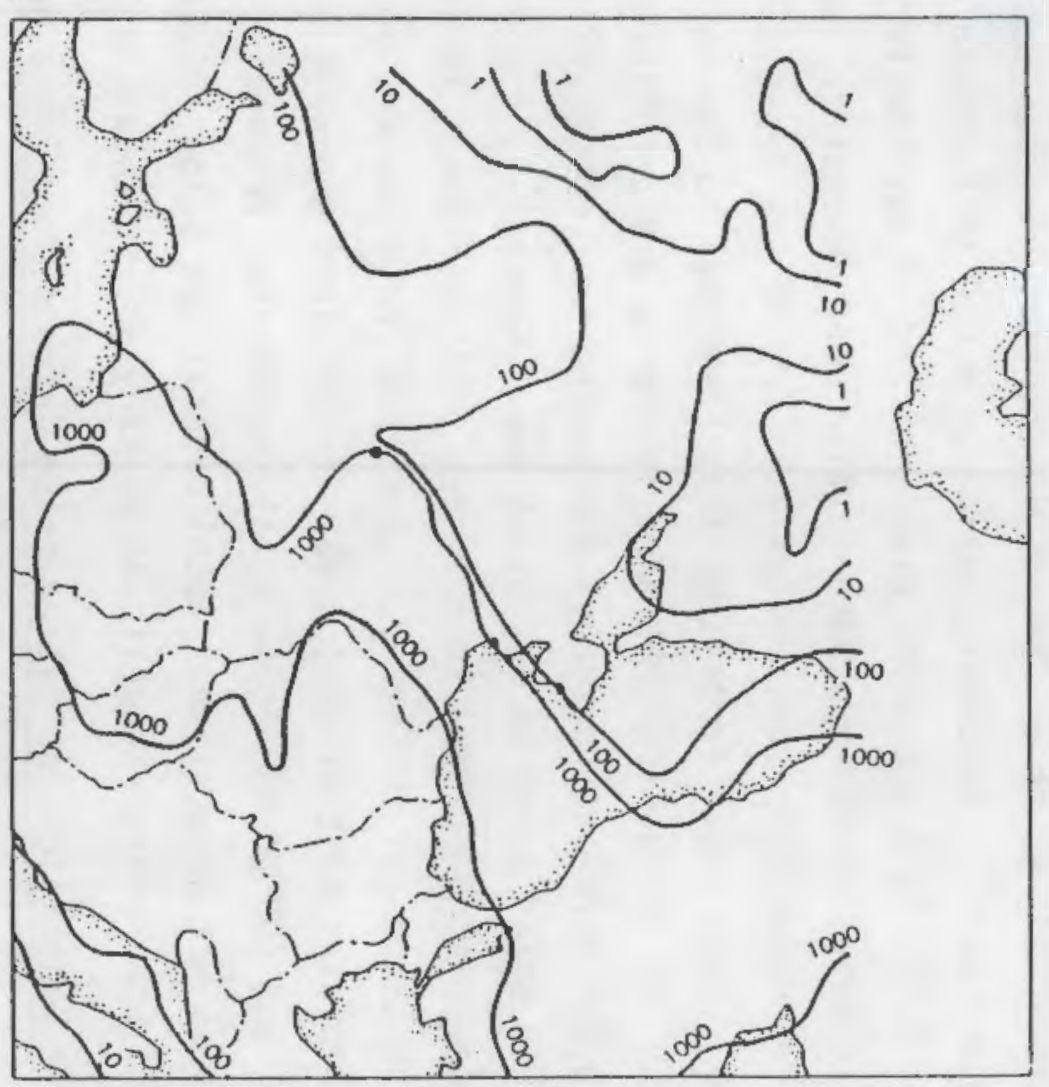

(b)

FIGURE 6.9. Cesium-137 Total Deposition $\left(\mathrm{Bq} / \mathrm{m}^{2}\right)$, Cumulative to May 15, 1986, Spatial Pattern from May 1 to May 5 Release for (a) Europe and (b) Eastern Europe 
Total deposition of cesium-137 greater than $1,000 \mathrm{~Bq} / \mathrm{m}^{2}$ is predicted over eastern Poland, eastern Czechoslovakia, eastern Hungary, the Ukraine, and Turkey. Immediately south of Chernobyl, the maximum total deposition is predicted as $10,000 \mathrm{~Bq} / \mathrm{m}^{2}$. Secondary maxima of 4,000 to $5,000 \mathrm{~Bq} / \mathrm{m}^{2}$, $3,000 \mathrm{~Bq} / \mathrm{m}^{2}$, and 5,000 to $6,000 \mathrm{~Bq} / \mathrm{m}^{2}$ are predicted in southeastern Poland/ eastern Czechoslovakia, in the southern Ukraine, and in eastern Turkey, respectively. Wet deposition contributes over $80 \%$ of the deposition for these secondary maxima. High total deposition from Chernobyl to the western Ukraine and from Chernobyl to the southern Ukraine is due to dry deposition, with approximately $10,000 \mathrm{~Bq} / \mathrm{m}^{2}$ at Chernobyl decreasing to $1,000 \mathrm{~Bq} / \mathrm{m}^{2}$ to the west and 3,000 to $4,000 \mathrm{~Bq} / \mathrm{m}^{2}$ north of the Black Sea. Generally, the predicted cesium-137 dry deposition pattern is oriented north-northwest to south-southeast from Stockholm to Chernobyl to Turkey. Less than $100 \mathrm{~Bq} / \mathrm{m}^{2}$ dry deposition of cesium-137 is predicted east of that area. At Helsinki and east of Moscow, 600 to $700 \mathrm{~Bq} / \mathrm{m}^{2}$ and 300 to $400 \mathrm{~Bq} / \mathrm{m}^{2}$ total deposition, respectively, is predicted mostly as wet deposition. Total depositions below $100 \mathrm{~Bq} / \mathrm{m}^{2}$ are predicted west of the Federal Republic of Germany and southeast of Chernobyl.

\subsubsection{Cumulative Deposition for Intermediate Dates of May 1 and May 5}

Cumulative deposition spatial patterns for two intermediate times provide an alternative way to assess how and when deposition occurred. In contrast to deposition patterns on May 15 resulting from specific release periods previously presented, patterns at intermediate times allow comparison to available measured cumulative deposition. Spatial patterns of cumulative deposition from April 26 to May 1 are given in Figures 6.10 to 6.13. Total deposition patterns for Europe and eastern Europe are presented for cesium-137 and iodine131 in Figures 6.10 and 6.11 , respectively. Contributions of wet and dry deposition to the total deposition pattern are then given in Figures 6.12 and 6.13 for cesium-137 and iodine-131, respectively. In Figures 6.14 to 6.17 , corresponding spatial patterns are presented for deposition cumulative from April 26 to May 5.

Total deposition patterns of cesium-137 and iodine-131 cumulative from April 26 to May 1 reflect the high deposition extending northwest of Chernobyl to south-central Finland resulting from the initial release (Figures 6.10 and 6.11). High deposition extending east and also southeast of Finland results 


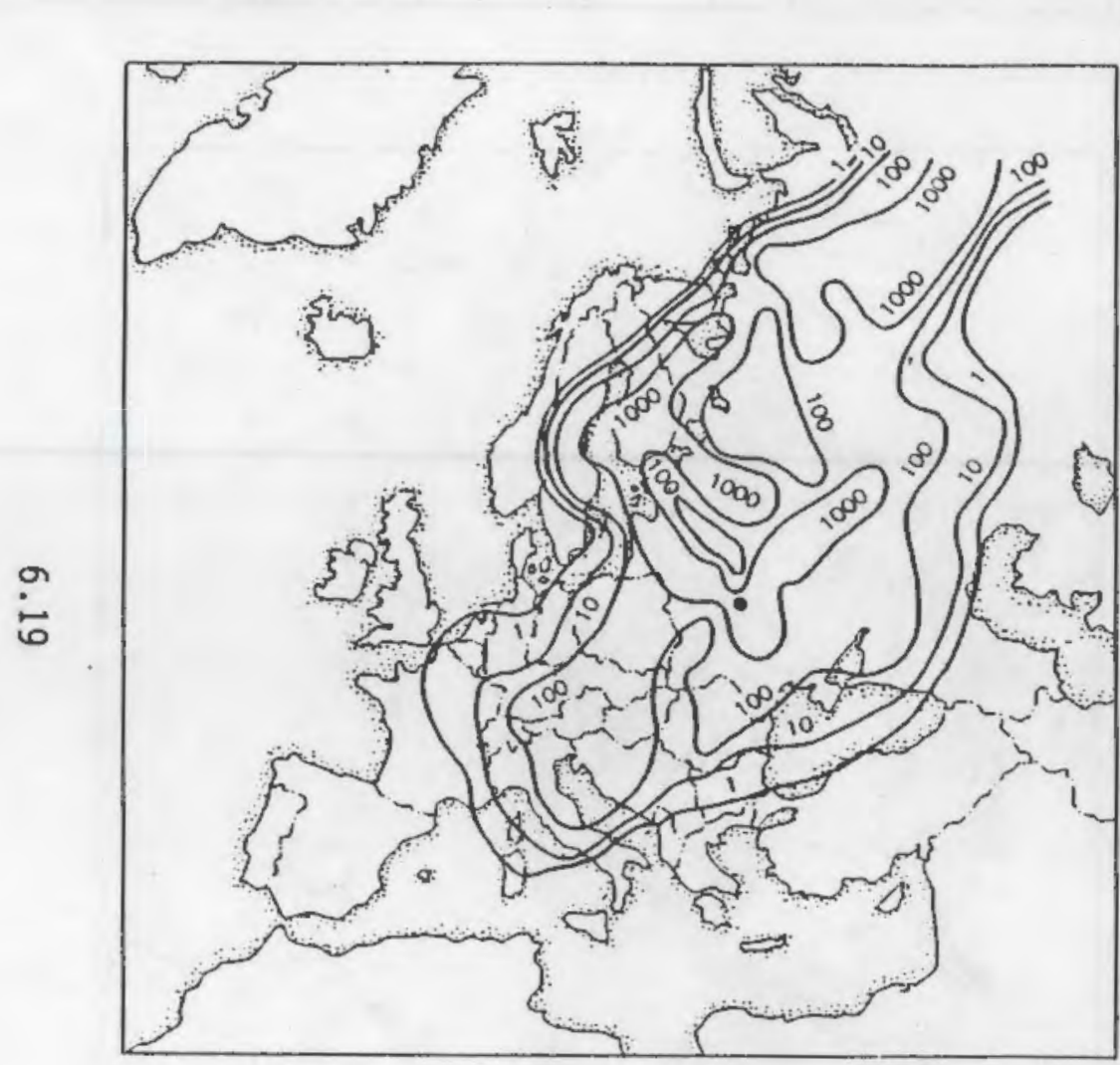

(a)

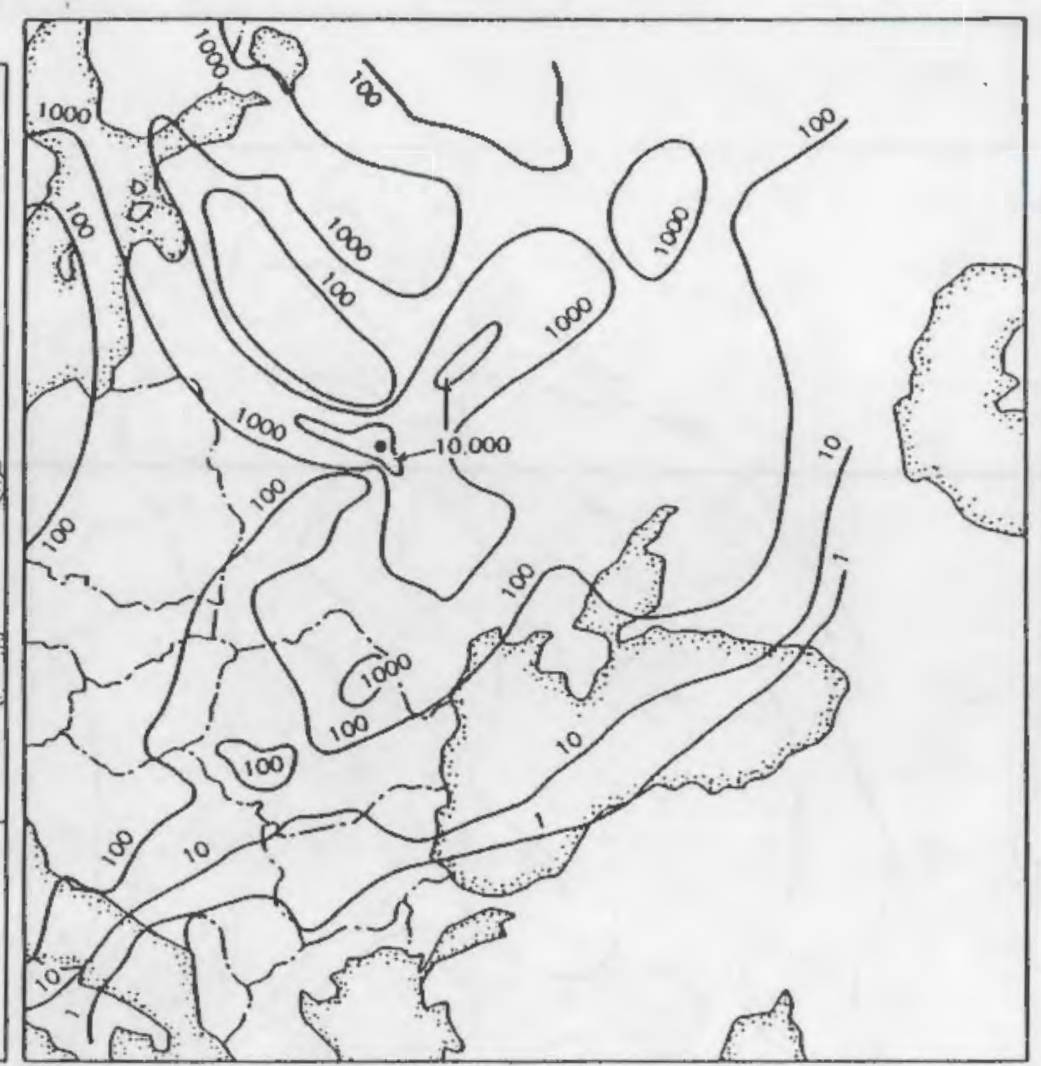

(b)

FIGURE 6.10. Cesium-137 Total Deposition $\left(\mathrm{Bq} / \mathrm{m}^{2}\right)$, Cumulative to May 1, 1986, Spatial Pattern for (a) Europe and (b) Eastern Europe 


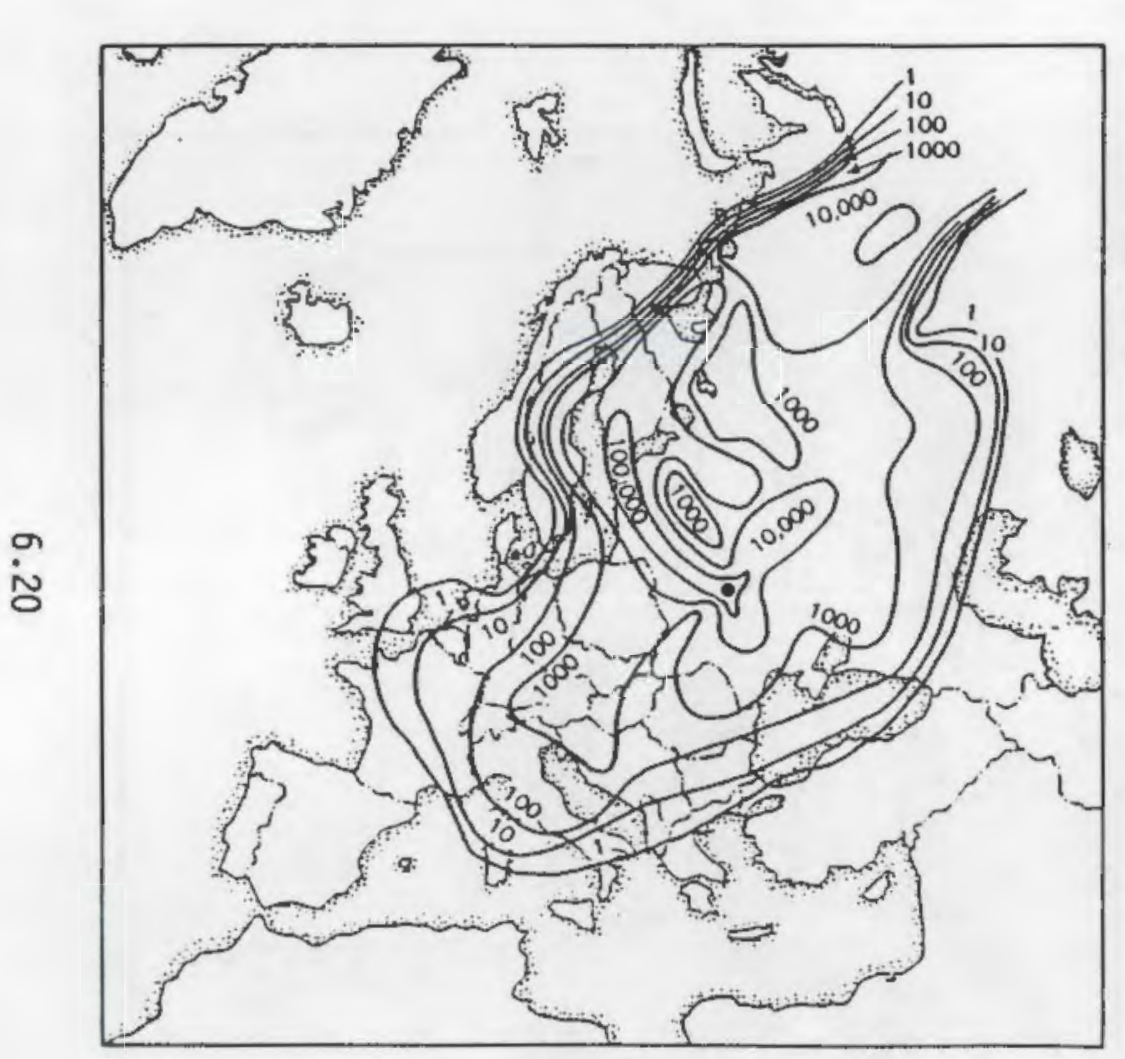

(a)

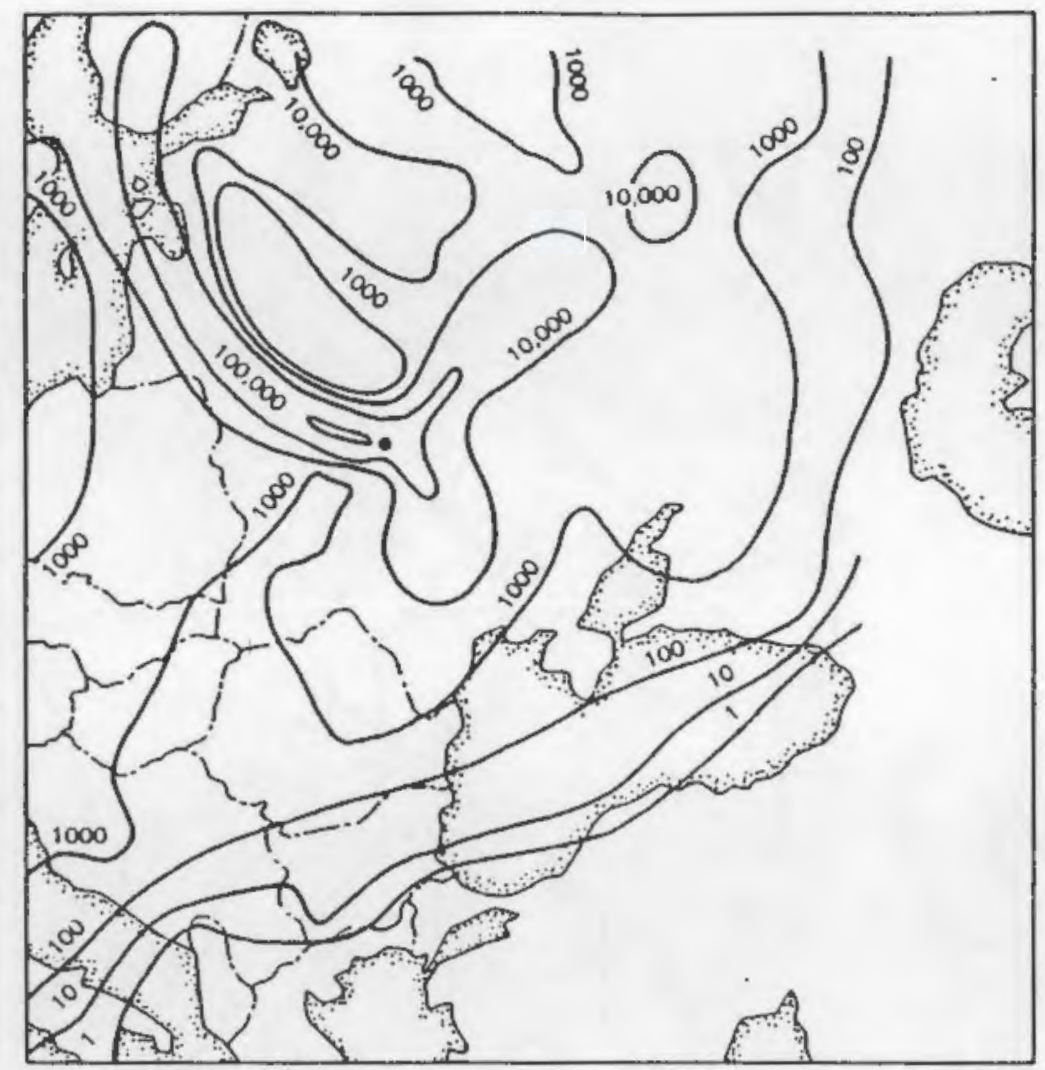

(b)

FIGURE 6.11. Iodine-131 Total Deposition $\left(\mathrm{Bq} / \mathrm{m}^{2}\right)$, Cumulative to May 1, 1986, Spatial Pattern for (a) Europe and (b) Eastern Europe 


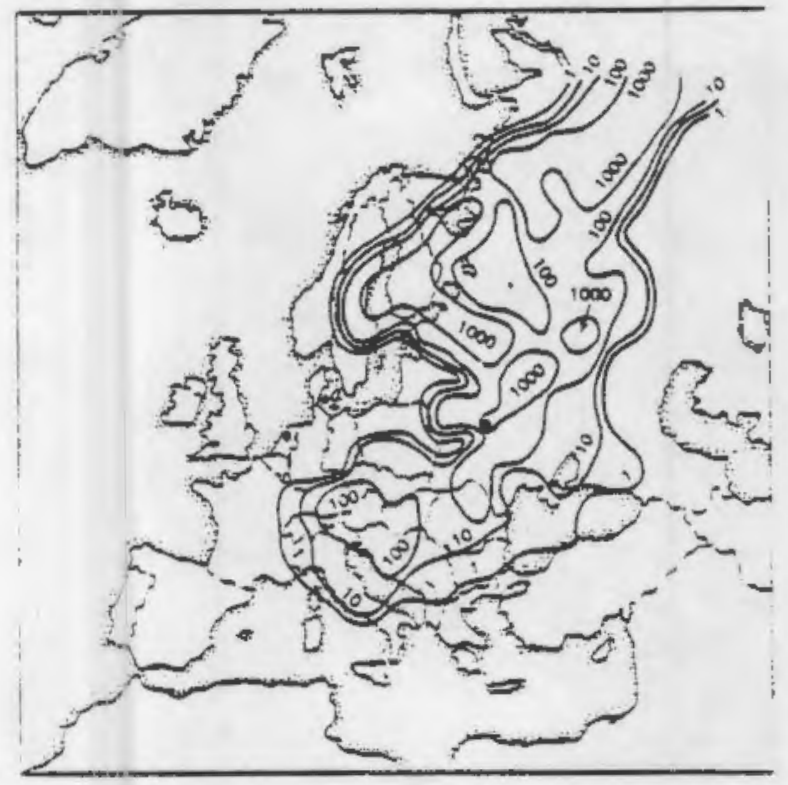

(a)

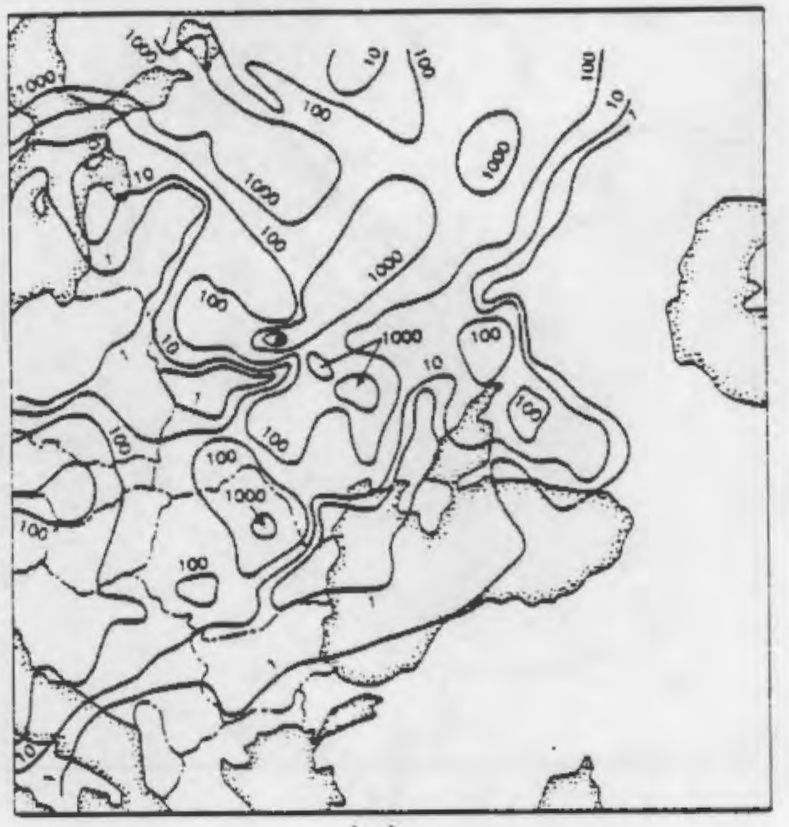

(b)
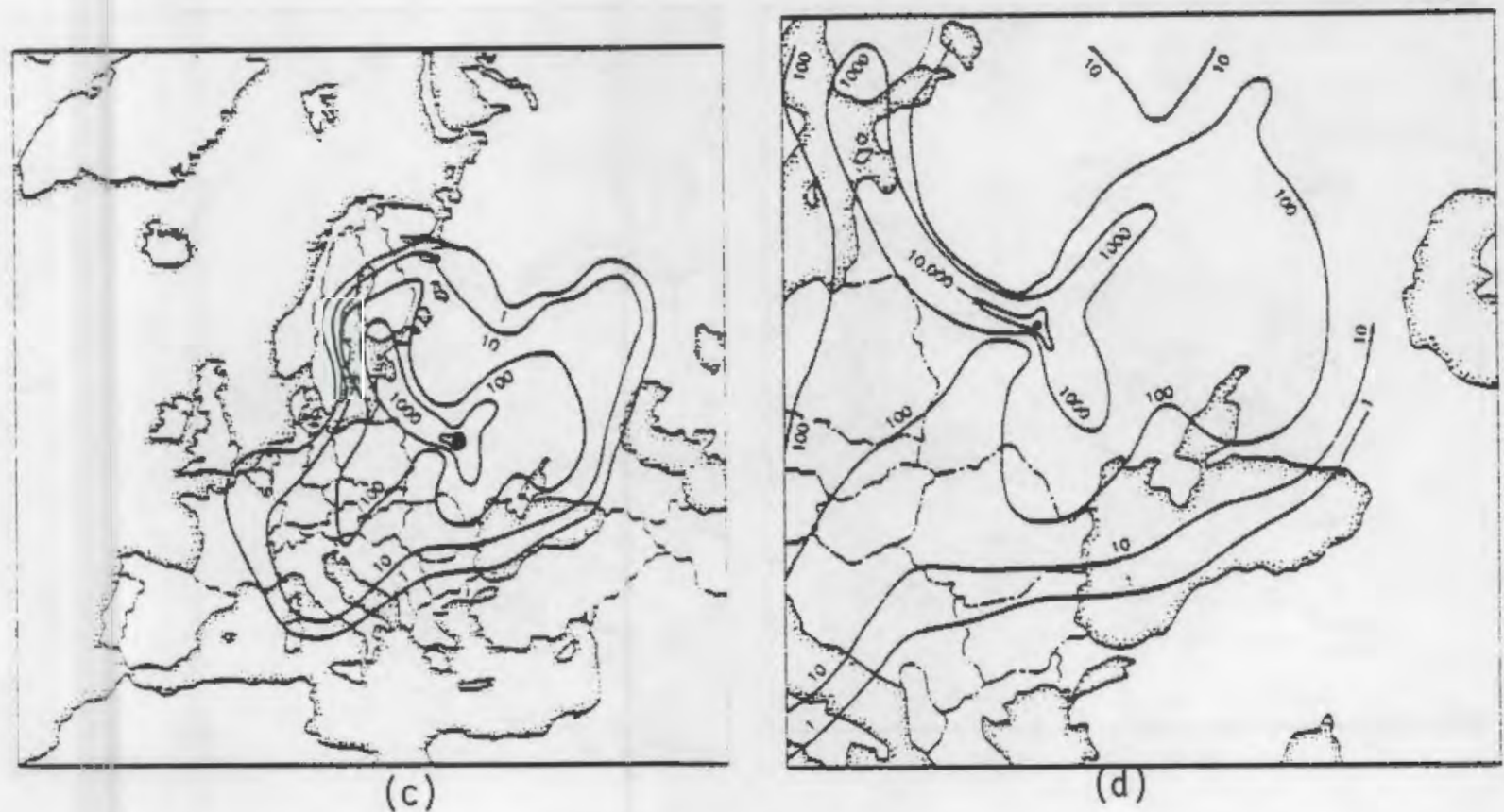

FIGURE 6.12. Cesium-137 Wet $(\mathrm{a}, \mathrm{b})$ and Dry $(\mathrm{c}, \mathrm{d})$ Deposition $\left(\mathrm{Bq} / \mathrm{m}^{2}\right)$, Cumulative to May 1, 1986, Spatial Patterns for Europe and Eastern Europe 


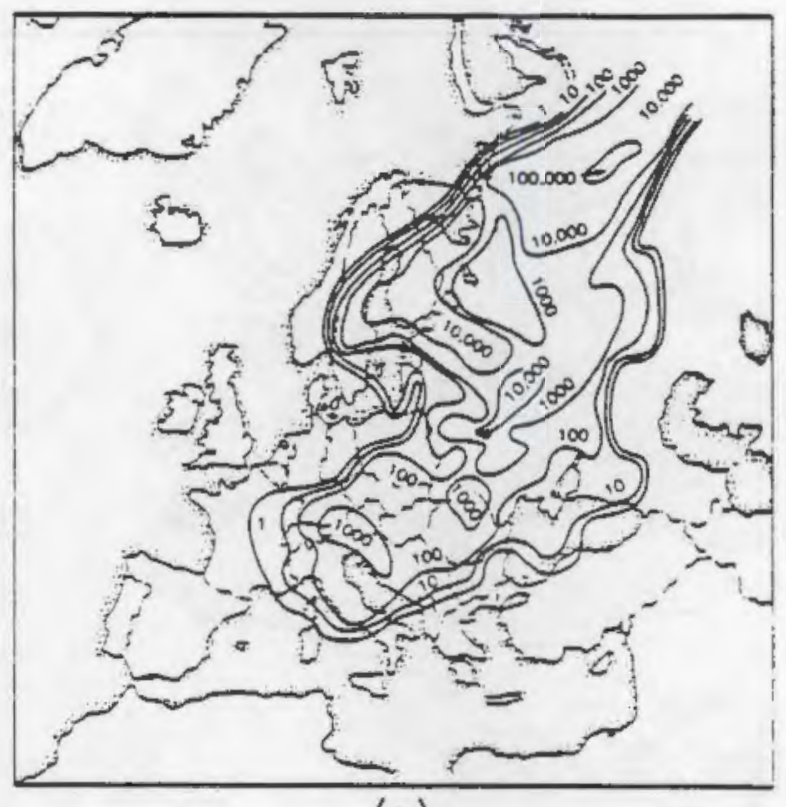

(a)

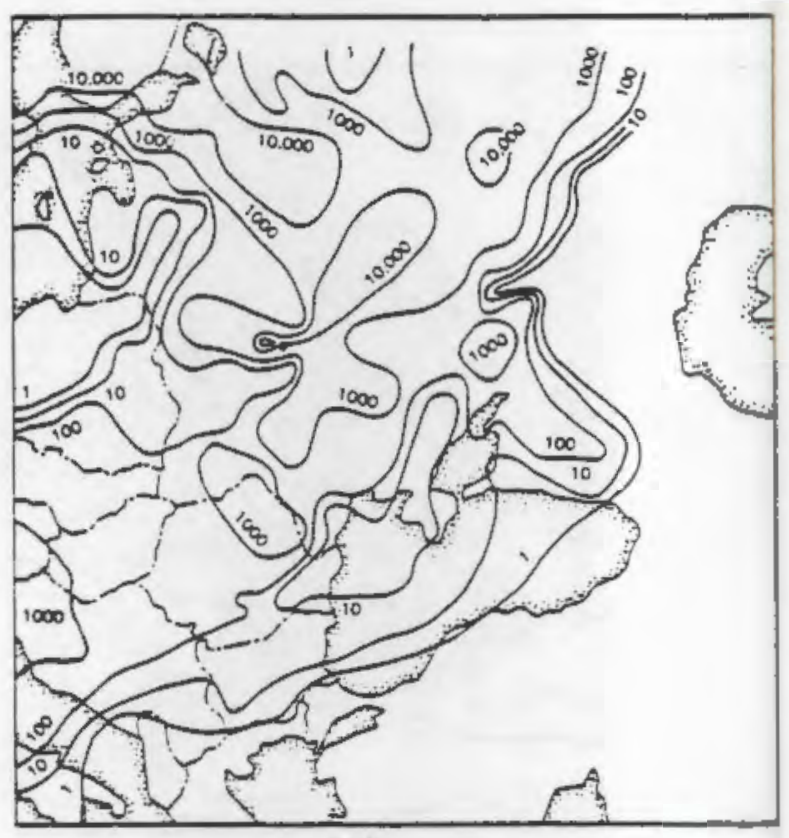

(b)

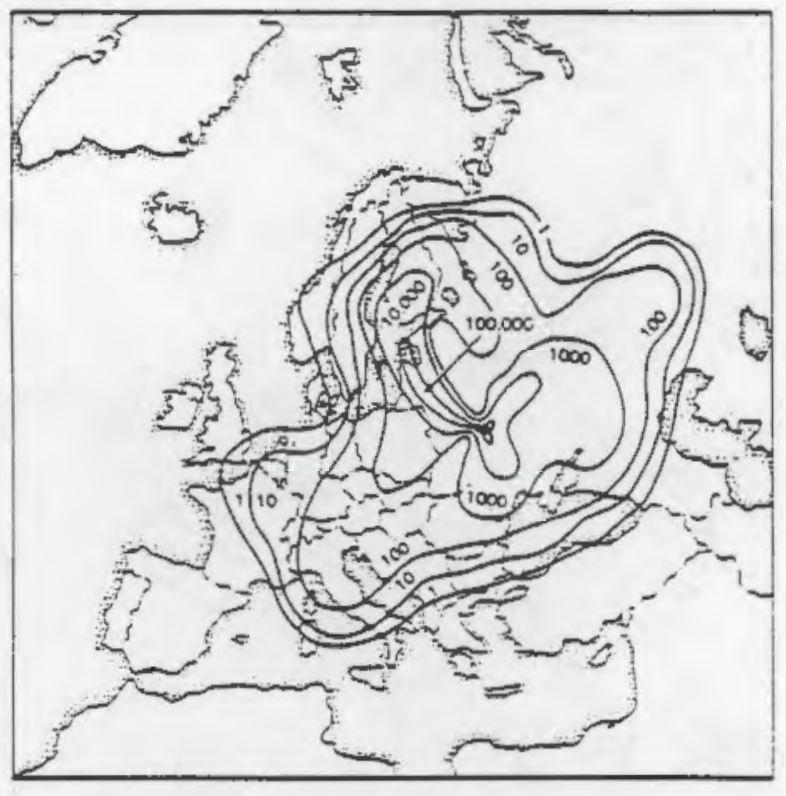

(c)

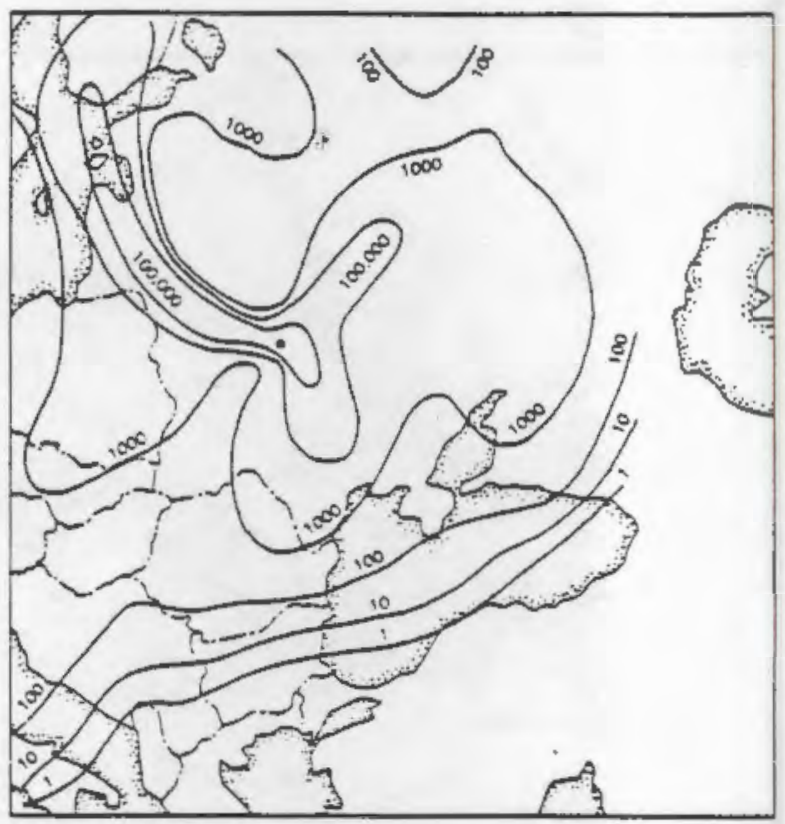

(d)

FIGURE 6.13. Iodine-131 Wet $(\mathrm{a}, \mathrm{b})$ and Dry $(\mathrm{c}, \mathrm{d})$ Deposition $\left(\mathrm{Bq} / \mathrm{m}^{2}\right)$, Cumulative to May 1, 1986, Spatial Patterns for Europe and Eastern Europe 


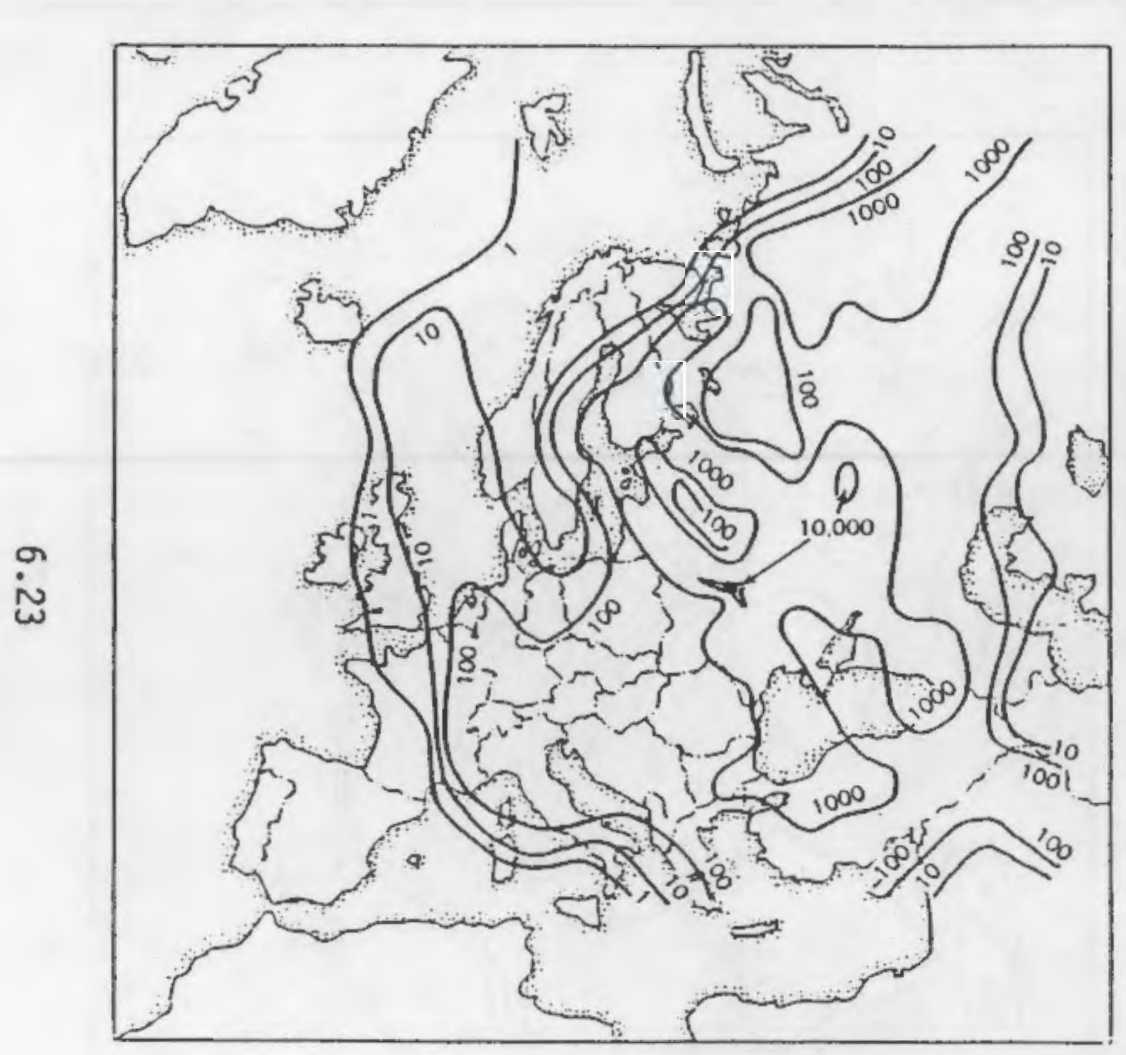

(a)

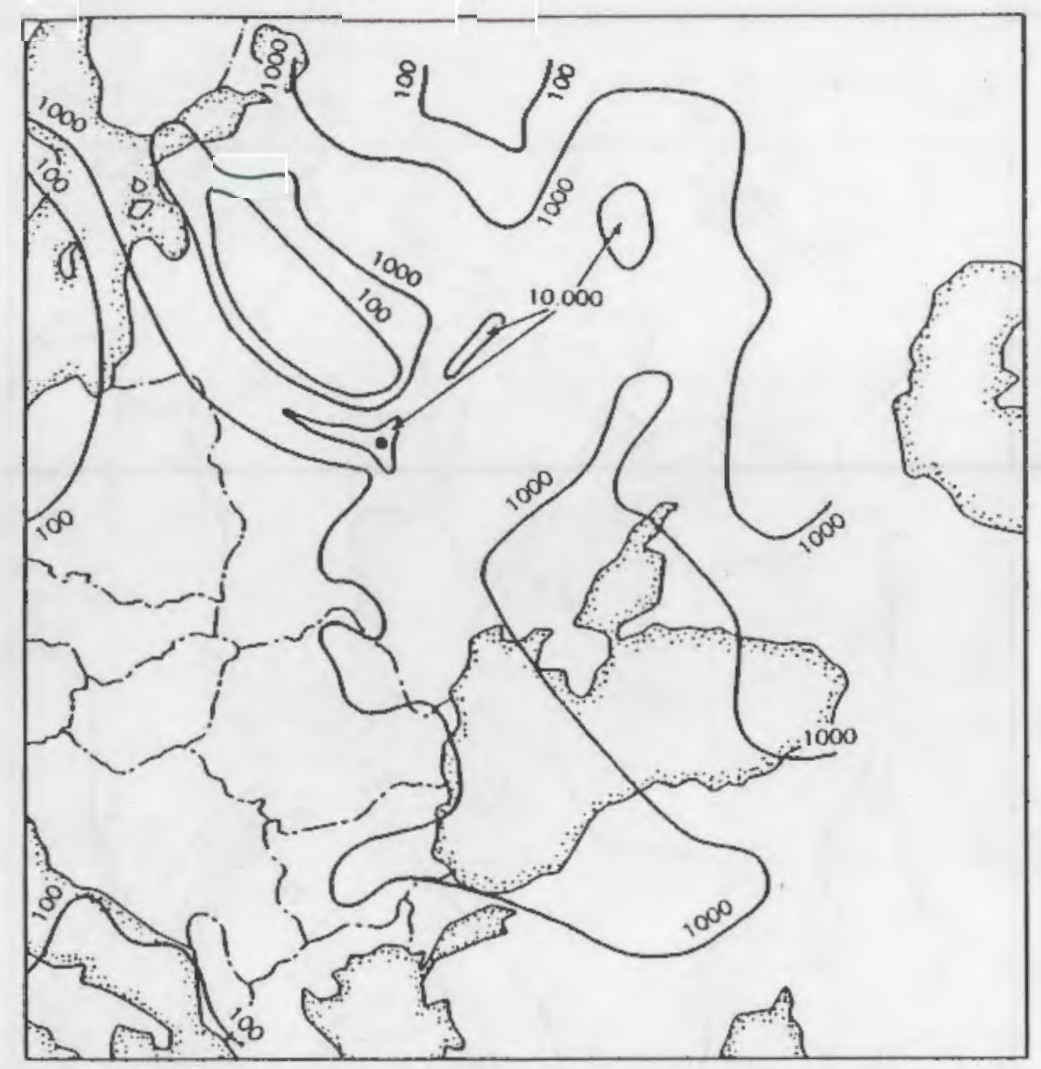

(b)

FIGURE 6.14. Cesium-137 Total Deposition (Bq/m²), Cumulative to May 5, 1986, Spatial Pattern for (a) Europe and (b) Eastern Europe 


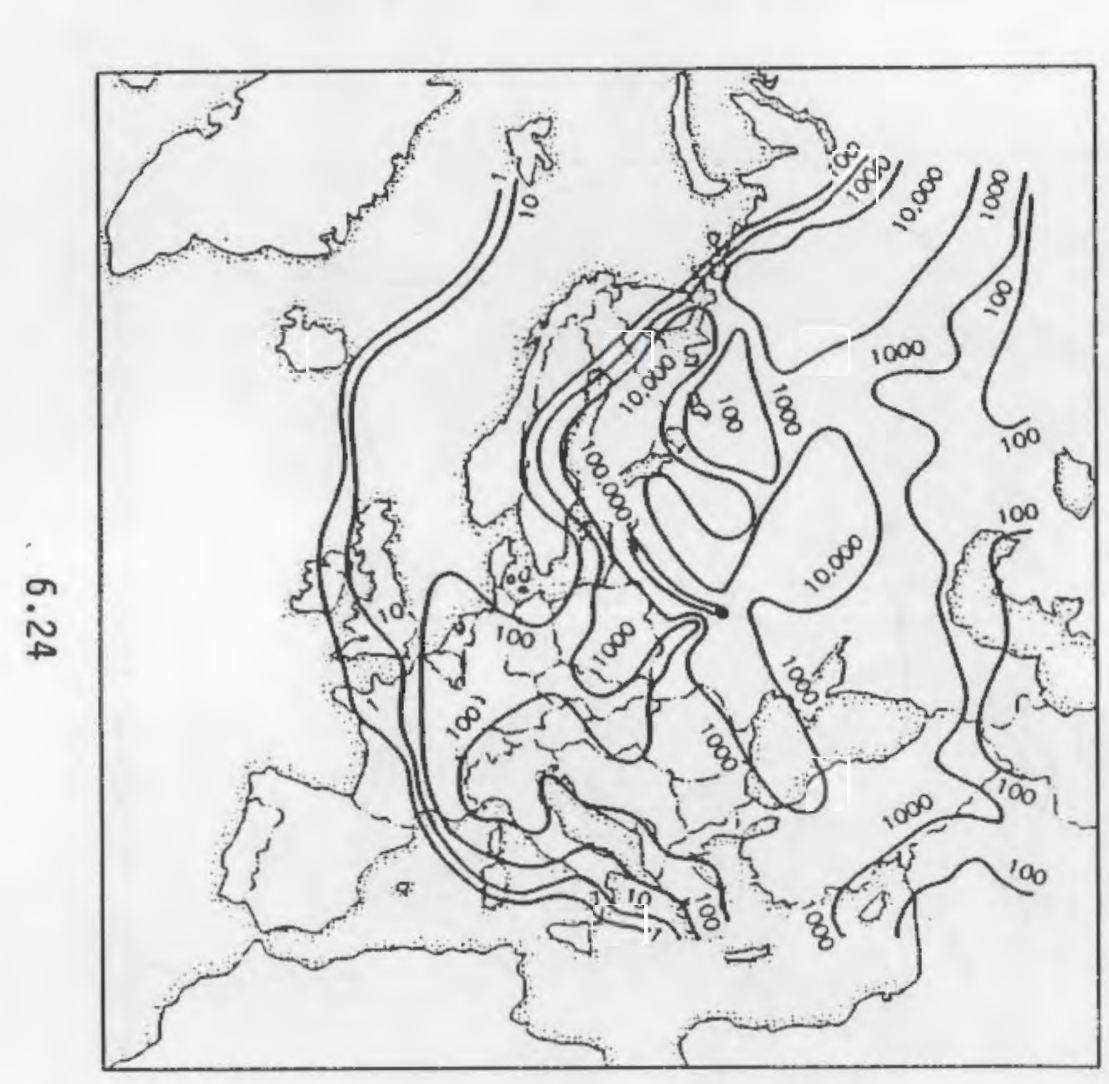

(a)

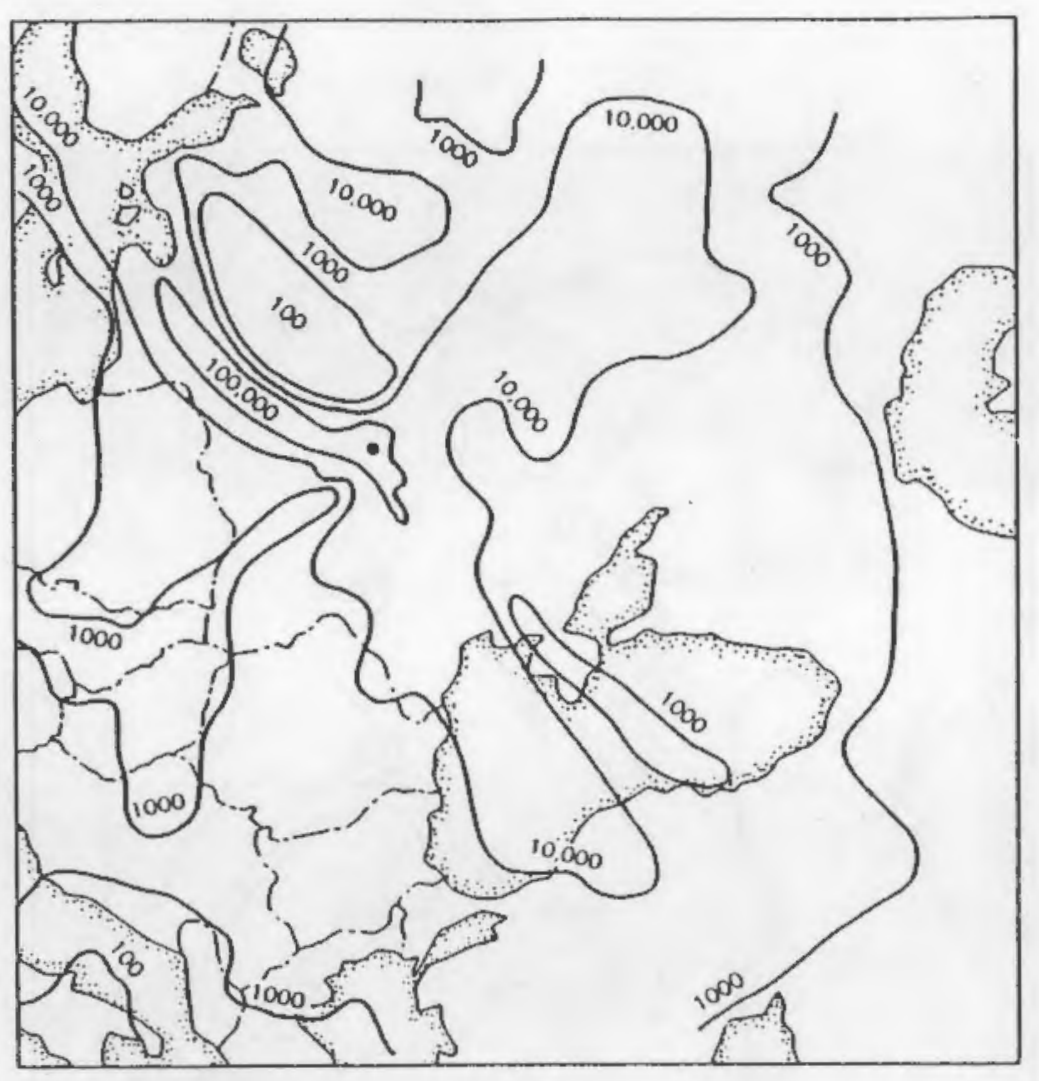

(b)

FIGURE 6.15. Iodine-131 Total Deposition $\left(\mathrm{Bq} / \mathrm{m}^{2}\right)$, Cumulative to May 5, 1986, Spatial Pattern for (a) Europe and (b) Eastern Europe 


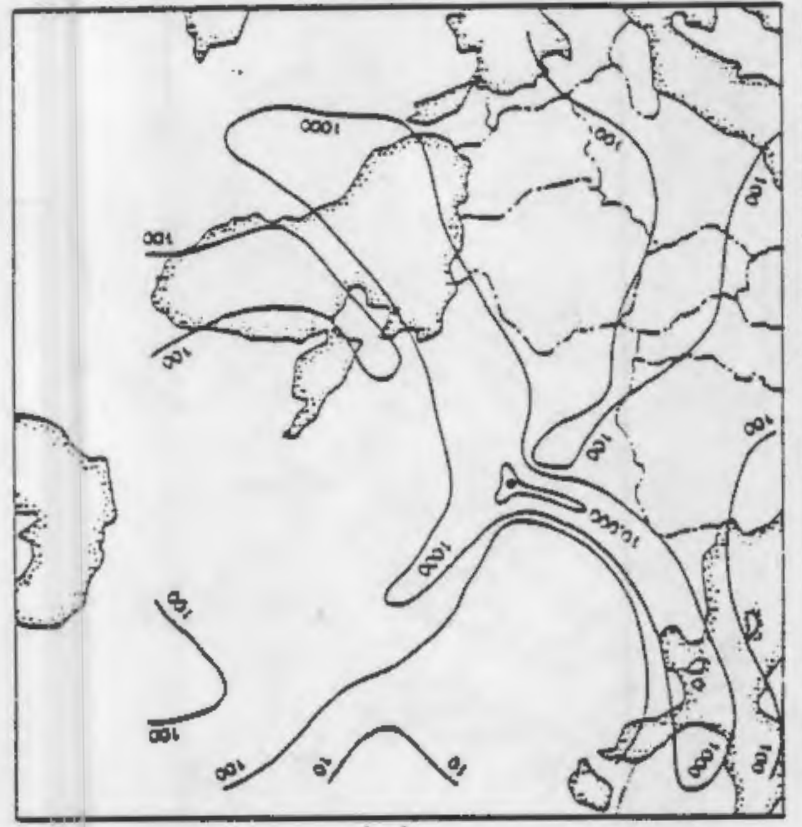

(a)

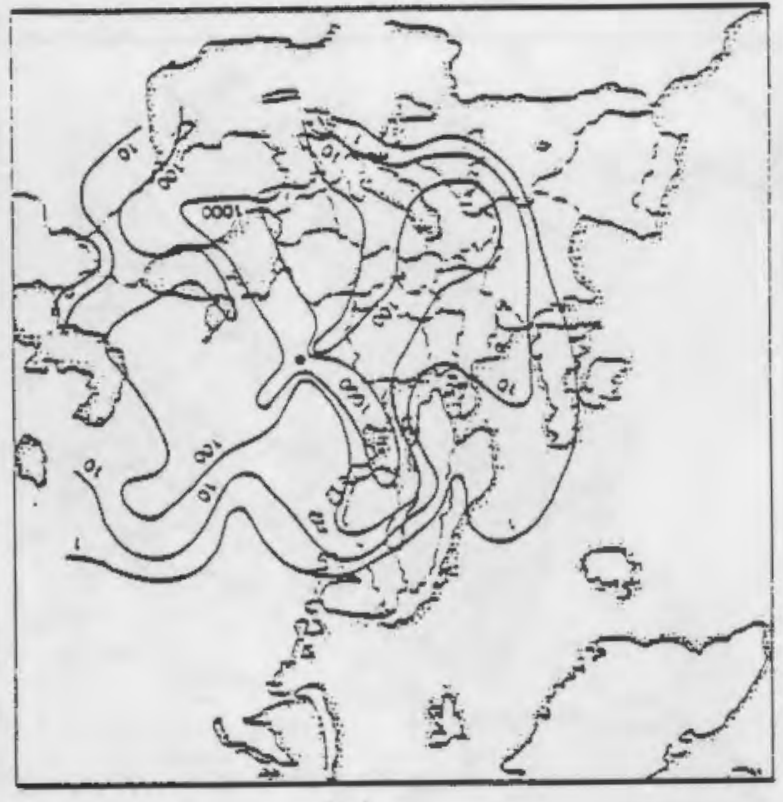

(b)

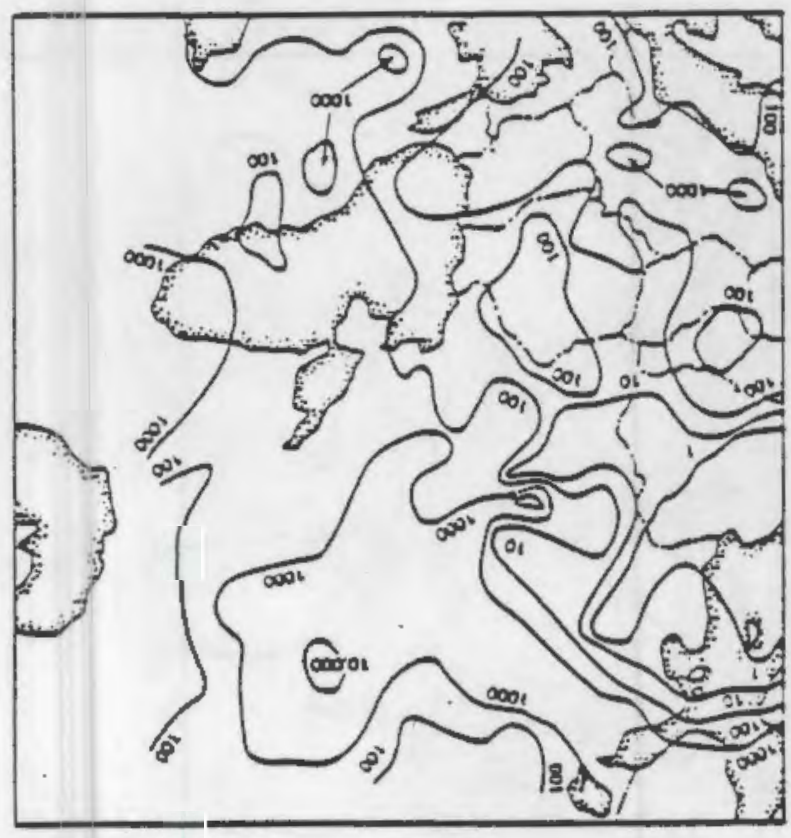

(c)

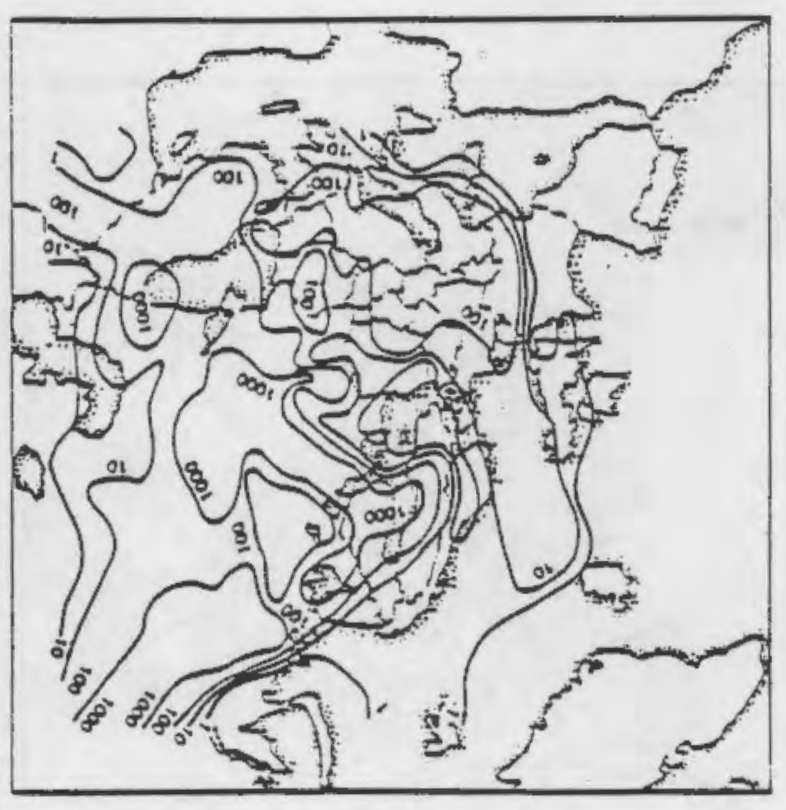

(d)

FIGURE 6.16. Cesium-137 Wet $(\mathrm{a}, \mathrm{b})$ and Dry $(\mathrm{c}, \mathrm{d})$ Deposition $\left(\mathrm{Bq} / \mathrm{m}^{2}\right)$, Cumulative to May 5, 1986, Spatial Patterns for Europe and Eastern Europe 


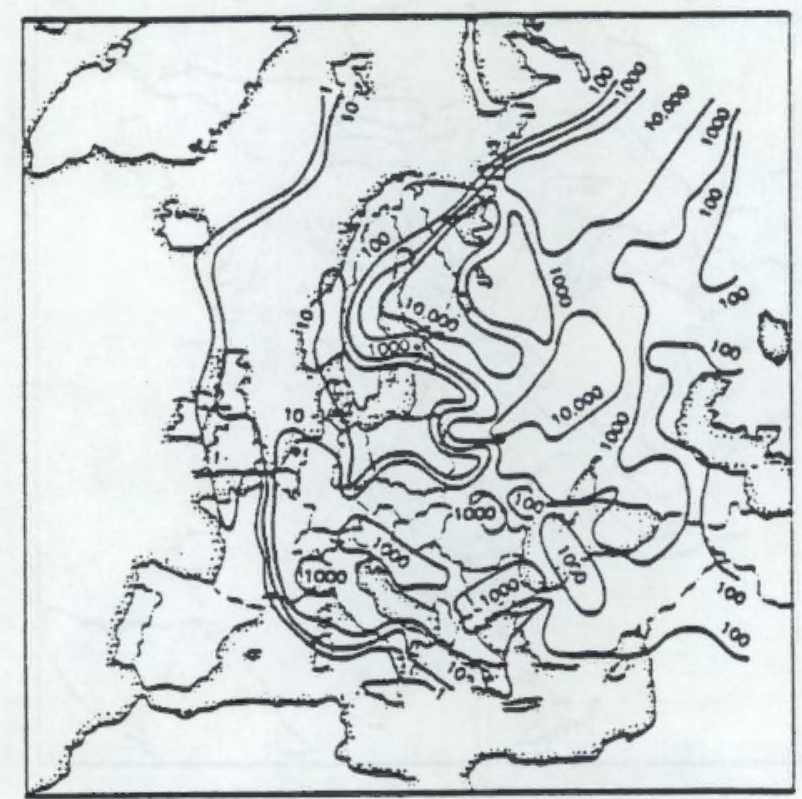

(a)

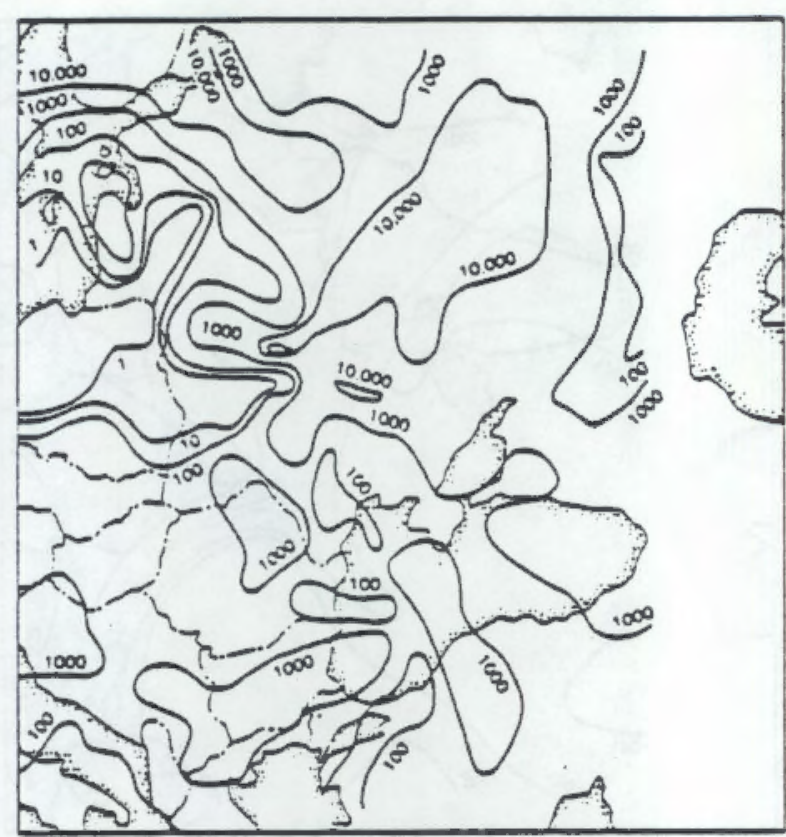

(b)

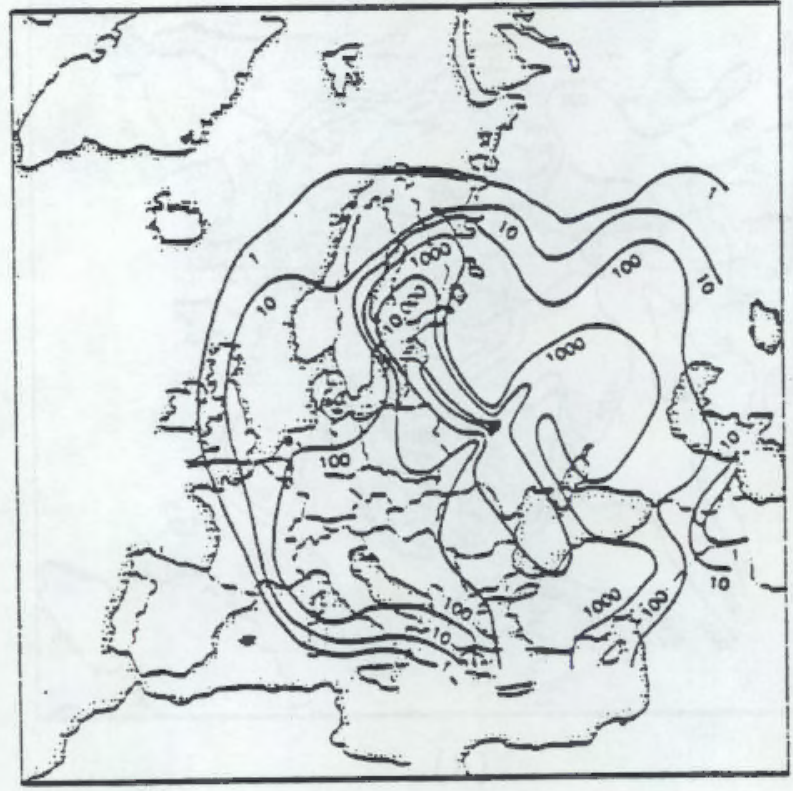

(c)

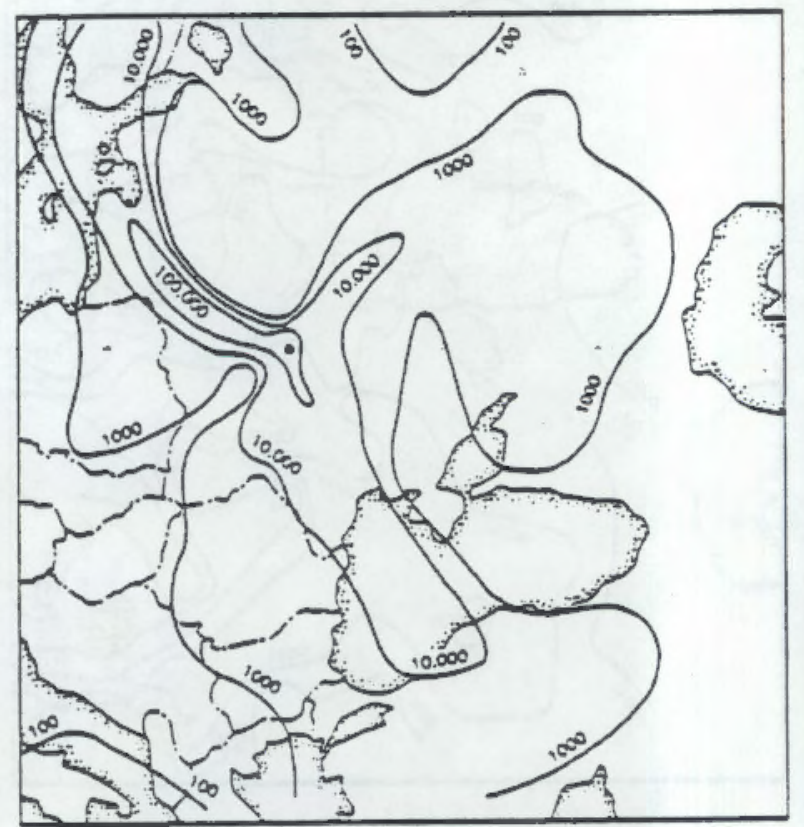

(d)

FIGURE 6.17 . Iodine-131 Wet $(\mathrm{a}, \mathrm{b})$ and Dry $(\mathrm{c}, \mathrm{d})$ Deposition $\left(\mathrm{Bq} / \mathrm{m}^{2}\right)$, Cumulative to May 5, 1986, Spatial Patterns for Europe and Eastern Europe 
from wet deposition (Figures $6.12 a$ and $6.13 a$ ). The same occurs for high deposition amounts south of Novaya Zemlya. Material released during the first $24 \mathrm{~h}$ is mainly responsible for these regions of high deposition. East, and to some extent south, of Chernobyl, total deposition greater than $1,000 \mathrm{~Bq} / \mathrm{m}^{2}$ is from releases from April 29 to May 1. Dry deposition only occurs immediately to the south while both wet and dry deposition occur to the east. Part of the wet deposition to the east may be from material released on April 26 that was transported to Finland and was carried by upper-level winds back toward the south.

Total deposition patterns of cesium-137 and iodine-131 cumulative from April 26 to May 5 (Figures 6.14 and 6.15) are more difficult to interpret in terms of when material was released. By May 5 all material is assumed to be released and the deposition patterns begin to reflect the May 15 cumulative deposition patterns. Between May 1 and May 5 the primary transport path is from the southeast to the southwest. Hence the May 5 deposition pattern includes high deposition regions to the southeast and southwest of Chernobyl. From Chernobyl to central Turkey (Figures 6.16 and 6.17), most deposition occurs as dry deposition but several areas in central Turkey had wet deposition. East of Chernobyl additional wet deposition occurred between May 1 and May 5 .

\subsection{DEPOSITION TEMPORAL PATTERN AT SELECTED LOCATIONS}

Daily deposition amounts are estimated for selected locations in eastern and western Europe to enable the temporal pattern of deposition to be examined. For some locations total deposition measurements are available for comparison to MLAM-estimated wet and total deposition. Comparison of estimated and measured deposition amounts provides information on source-term assumptions and ability of MLAM to model the complex meteorological conditions with the available meteorological input data. Estimation of daily deposition for locations without measurements is done to aid in understanding how the total cumulative deposition on May 15 occurred.

Daily measured deposition and model-estimated wet and total deposition values are compared in Figure 6.18 graphically and in Table 6.2 numerically. For Helsinki, Bilthoven, Budapest, and Varese, the plots suggest that the 
Helsinki, Finland

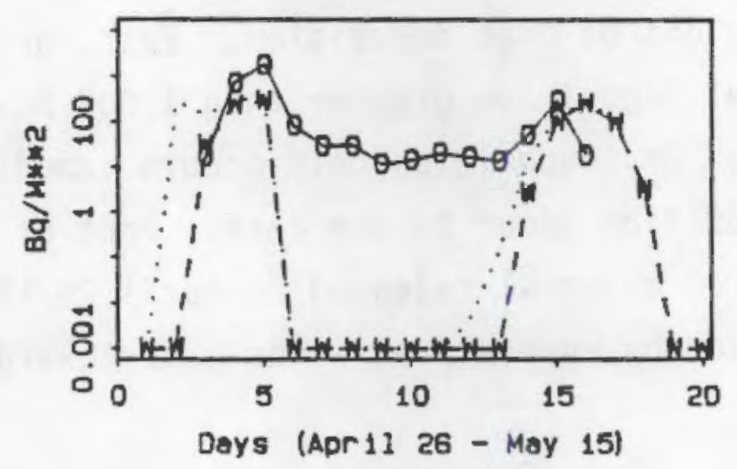

Bilthoven, Netherlands

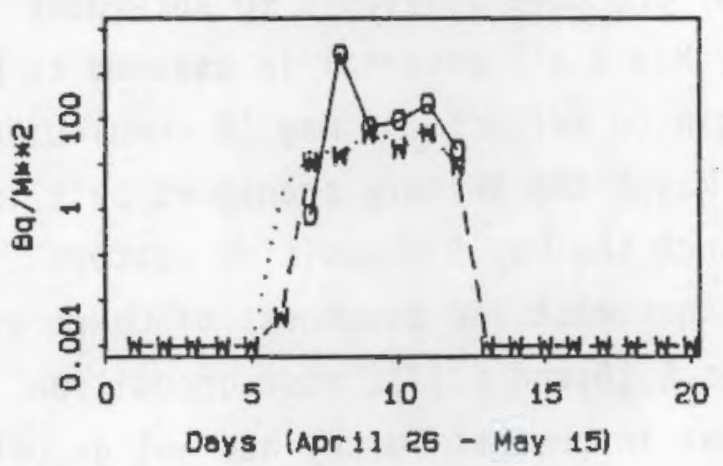

Riso, Denmark

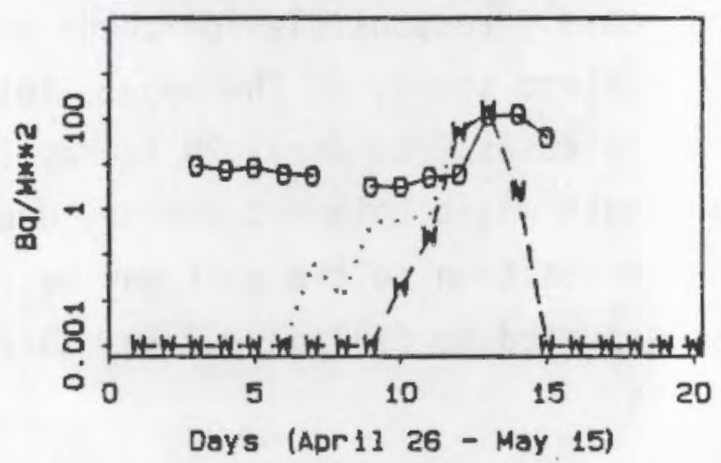

Budapest, Hungary

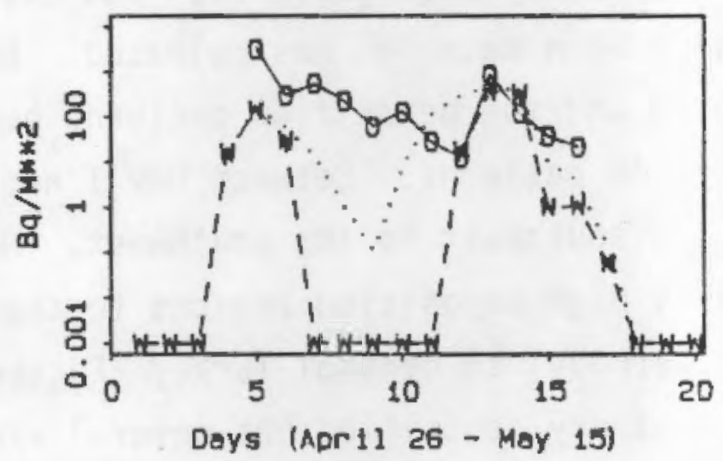

Varese, Italy

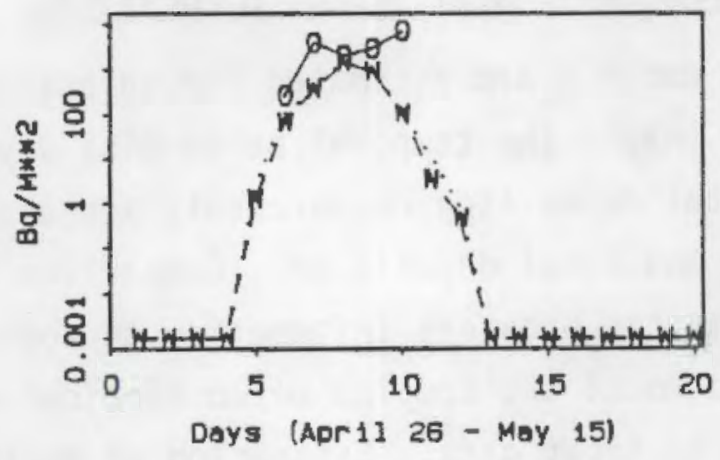

FIGURE 6.18. Cesium-137 Daily Deposition $\left(\mathrm{Bq} / \mathrm{m}^{2}\right)$ at Helsinki, Ris $\phi$, Bilthoven, Budapest, and Varese. Measured deposition denoted by 0 and solid line, modeled wet deposition denoted by $W$ and dashed Line, and modeled total deposition by dotted line. 
TABLE 6.2. Observed and Modeled (Wet and Total) Oeposition $\left(\mathrm{Bq} / \mathrm{m}^{2}\right)$ for Selected Cities

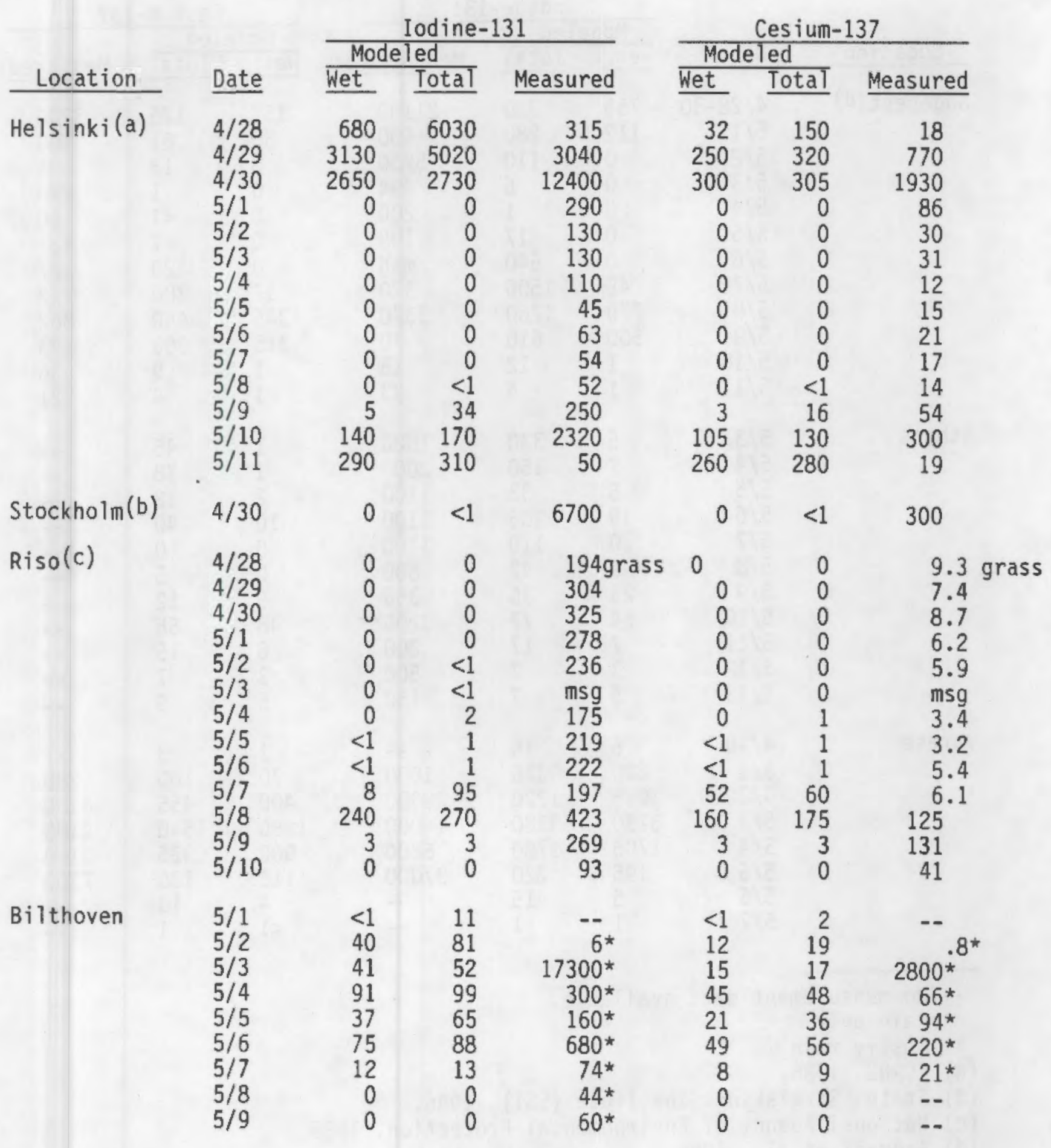


TABLE 6.2. (contd)

\begin{tabular}{|c|c|c|c|c|c|c|c|}
\hline \multirow[b]{2}{*}{ Location } & \multirow[b]{2}{*}{ Date } & \multicolumn{3}{|c|}{ Modeled } & \multicolumn{2}{|c|}{ Modeled } & \multirow[b]{2}{*}{ Measured } \\
\hline & & Wet & Total & Measured & Wet & TotaT & \\
\hline Budapest (d) & $\begin{array}{l}4 / 28-30 \\
5 / 1 \\
5 / 2 \\
5 / 3 \\
5 / 4 \\
5 / 5 \\
5 / 6 \\
5 / 7 \\
5 / 8 \\
5 / 9 \\
5 / 10 \\
5 / 11\end{array}$ & $\begin{array}{r}755 \\
112 \\
0 \\
0 \\
0 \\
0 \\
0 \\
45 \\
770 \\
500 \\
1 \\
1\end{array}$ & $\begin{array}{r}920 \\
280 \\
110 \\
6 \\
1 \\
17 \\
540 \\
1500 \\
1260 \\
610 \\
12 \\
4\end{array}$ & $\begin{array}{r}21100 \\
600 \\
5250 \\
494 \\
200 \\
198 \\
\mathrm{msg} \\
320 \\
3370 \\
70 \\
16 \\
33\end{array}$ & $\begin{array}{r}155 \\
30 \\
0 \\
0 \\
0 \\
0 \\
0 \\
17 \\
345 \\
315 \\
1 \\
1\end{array}$ & $\begin{array}{r}175 \\
61 \\
13 \\
1 \\
<1 \\
7 \\
120 \\
300 \\
460 \\
360 \\
9 \\
4\end{array}$ & $\begin{array}{r}3200 \\
300 \\
546 \\
230 \\
60 \\
131 \\
27 \\
12 \\
862 \\
123 \\
36 \\
21\end{array}$ \\
\hline Athens & $\begin{array}{l}5 / 3 \\
5 / 4 \\
5 / 5 \\
5 / 6 \\
5 / 7 \\
5 / 8 \\
5 / 9 \\
5 / 10 \\
5 / 11 \\
5 / 12 \\
5 / 13\end{array}$ & $\begin{array}{r}5 \\
2 \\
5 \\
19 \\
0 \\
0 \\
23 \\
64 \\
7 \\
3 \\
5\end{array}$ & $\begin{array}{r}330 \\
150 \\
33 \\
105 \\
110 \\
42 \\
36 \\
77 \\
17 \\
7 \\
7\end{array}$ & $\begin{array}{c}1000 \\
2000 \\
1100 \\
1100 \\
1100 \\
800 \\
350 \\
3200^{\star *} \\
200 \\
500 \\
150\end{array}$ & $\begin{array}{r}1 \\
1 \\
2 \\
10 \\
0 \\
0 \\
9 \\
48 \\
6 \\
3 \\
3 \\
5\end{array}$ & $\begin{array}{r}45 \\
38 \\
12 \\
40 \\
0 \\
5 \\
12 \\
56 \\
15 \\
7 \\
9\end{array}$ & $\begin{array}{l}-- \\
-- \\
-- \\
-- \\
-- \\
-- \\
-- \\
--\end{array}$ \\
\hline Varese & $\begin{array}{l}4 / 30 \\
5 / 1 \\
5 / 2 \\
5 / 3 \\
5 / 4 \\
5 / 5 \\
5 / 6 \\
5 / 7\end{array}$ & $\begin{array}{r}6 \\
220 \\
1045 \\
3230 \\
1705 \\
195 \\
5 \\
1\end{array}$ & $\begin{array}{r}16 \\
370 \\
1220 \\
3380 \\
1780 \\
220 \\
15 \\
1\end{array}$ & $\begin{array}{r}1000 \\
29000 \\
14000 \\
6800 \\
37000 \\
--\end{array}$ & $\begin{array}{r}1 \\
70 \\
400 \\
1480 \\
900 \\
115 \\
4 \\
<1\end{array}$ & $\begin{array}{r}3 \\
100 \\
455 \\
1540 \\
935 \\
130 \\
10 \\
1\end{array}$ & $\begin{array}{r}-- \\
280 \\
4100 \\
2100 \\
3100 \\
7300 \\
-- \\
--\end{array}$ \\
\hline
\end{tabular}

-- No measurement data available.

* Rain only

** Mostly rain

(a) FCRNS, 1986.

(b) Staten Straiskydds Institute (SSI), 1986.

(c) National Agency of Environmental Protection, 1986.

(d) Andrasi et al., 1986. 
model estimate of when material is initially deposited is approximately correct. Although the measured data at the same sites end before a pattern is clearly discernable, the end of the final deposition appears reasonably consistent. For Helsinki and Budapest the model estimates that no deposition occurred approximately 7 to 10 days after the accident, while the measured data indicate deposition occurred. No deposition is estimated to occur at Riso, Denmark, until May 7, but deposition is observed from April 28 to May 10. For Helsinki, Bilthoven, and Riso, meteorological conditions associated with the initial release resulted in MLAM transport errors as a result of a lack of massconsistent winds and de-emphasis of surface layer winds. Maximum estimated deposition (Table 6.2) is lower than maximum measured deposition for all cities. Because wet deposition is a major contributor to deposition, uncertainty of precipitation occurrence and non-availability of hourly precipitation rates are expected to account for a substantial fraction of the differences observed.

Model estimates of deposition for Ankara, Vienna, Bucharest, and Moscow (Figure 6.19) are provided to illustrate temporal patterns at locations in other regions. All of these cities show effects of the release within 5 days after the accident and indicate deposition greater than $1 \mathrm{~Bq} / \mathrm{m}^{2}$ is present up to 20 days after the accident. 

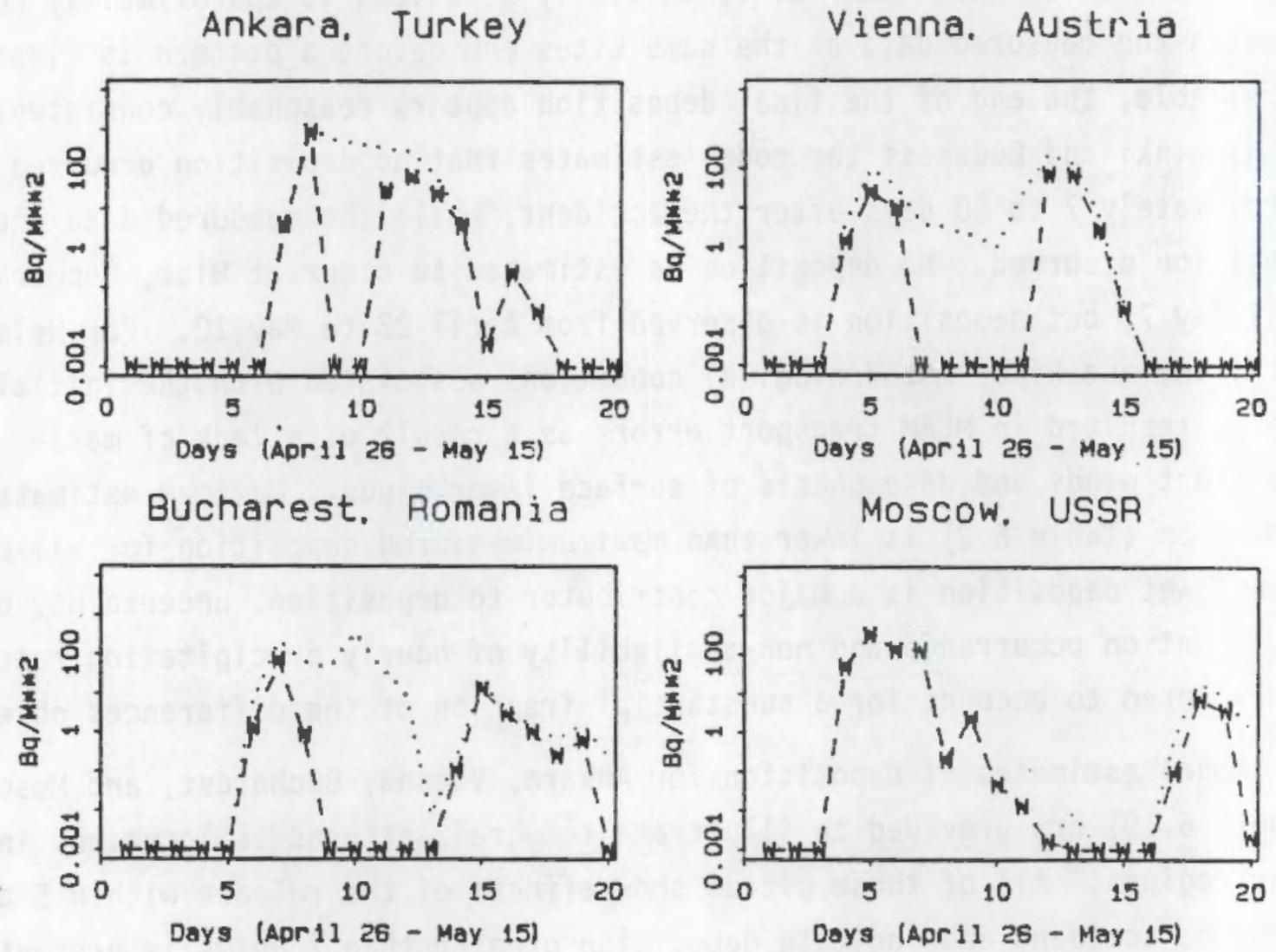

FIGURE 6.19. Cesium-137 Daily Deposition $\left(\mathrm{Bq} / \mathrm{m}^{2}\right)$ at Ankara, Vienna, Bucharest, and Moscow. Modeled wet deposition denoted by $W$ and dashed line and modeled total deposition by dotted line. 


\subsection{ESTIMATED SURFACE AIR CONCENTRATIONS}

Surface air concentrations for xenon-133, cesium-137, and iodine-131 are estimated to provide information on the daily spatial and temporal pattern associated with transport, diffusion, and deposition of radionuclides released. Contour plots (Figure 7.1) of xenon-133 daily surface air concentrations are included to indicate how a noble gas would transport and diffuse. By studying the daily patterns, an overview of transport path changes caused by meteorological conditions can be gained for the April 26 to May 13 time period. Time series plots of cesium-137 (Figure 7.2) and iodine-131 (Figure 7.3) surface air concentrations for five cities enable the plume-estimated arrival time to be coinpared with available measured data.

From April 26 to April 28, the plume traveled west-northwest from Chernobyl turning north toward the southern tip of Finland (Figure 7.1). Beginning on April 28 and continuing to April 29, the plume direction switched to east from Chernobyl and extended to south of Moscow. On April 30 and May 1, the plume direction turned toward the south until on May 2 through May 4 the plume extended south to Odessa and central Turkey. On the last day of release, the plume turned toward Romania and continued in that direction until approximately May 7. Subsequently, the plume continued to diffuse along a north-south line across central Europe and slowly moved east across Chernobyl. Portions of the plume on April 28 and April 29 moved west-southwest across central Europe toward northern Italy and then moved north across France and West Germany toward the United Kingdom. By obtaining measured daily data at specific locations and comparing to model-estimated concentrations or depositions, it would be possible to investigate the source-term time-of-release assumptions.

In Figures 7.2 and 7.3 , cesium-137 and iodine-131 estimated surface air concentration temporal patterns are compared to available measured patterns. Generally, where comparisons are possible, the estimated arrival of the plume is consistent with the measured pattern. Based on the analysis of daily xenon-133 spatial patterns (Table 7.1), air concentrations at Helsinki, Riso, Bilthoven, Budapest, and Varese are believed to be associated with material released between April 26 and April 28. 

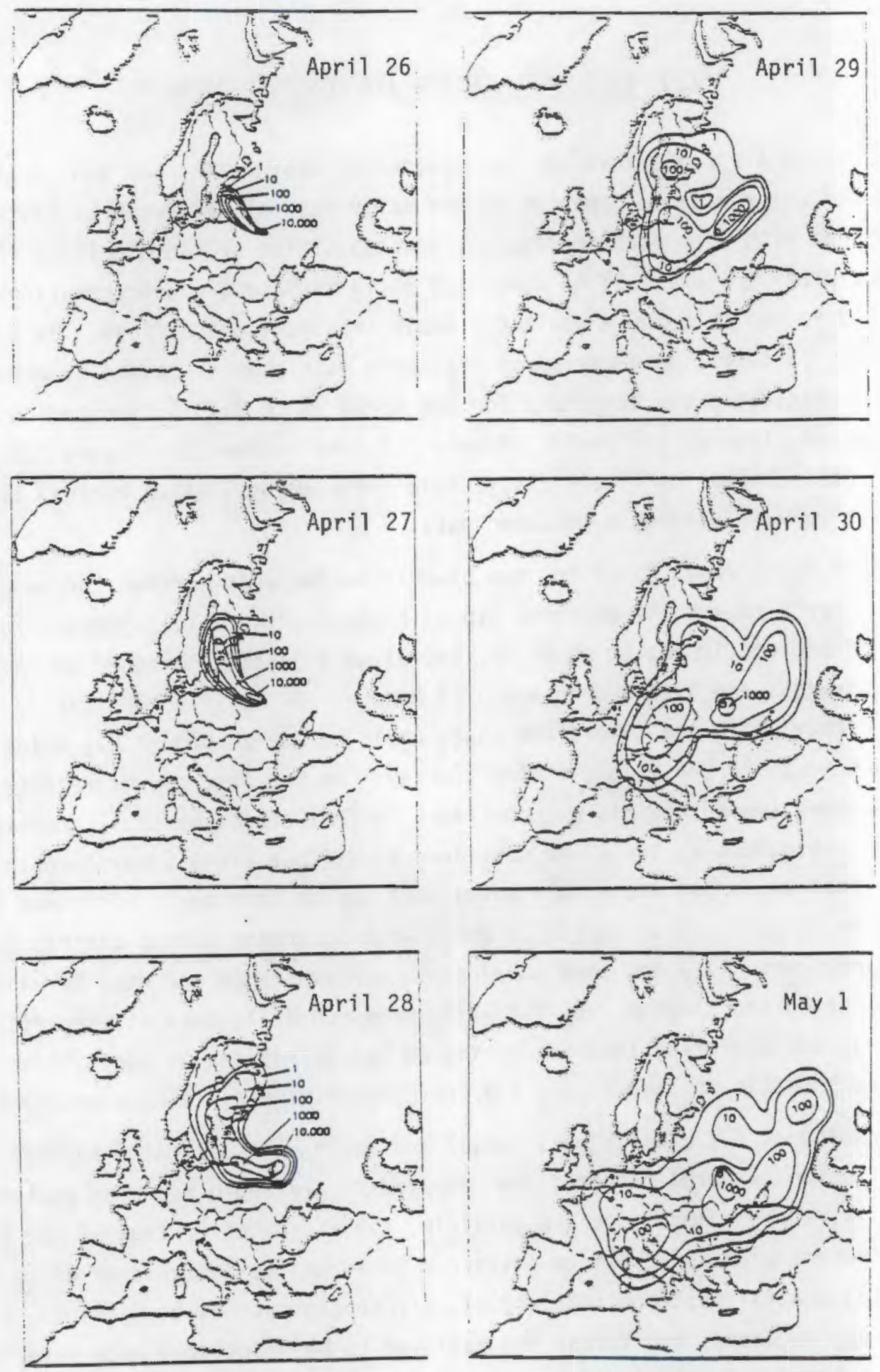

FIGURE 7.1. Xenon-133 Daily Air Concentration (Bq/m 3 ) Spatial Pattern for April 26 to May 13, 1986 

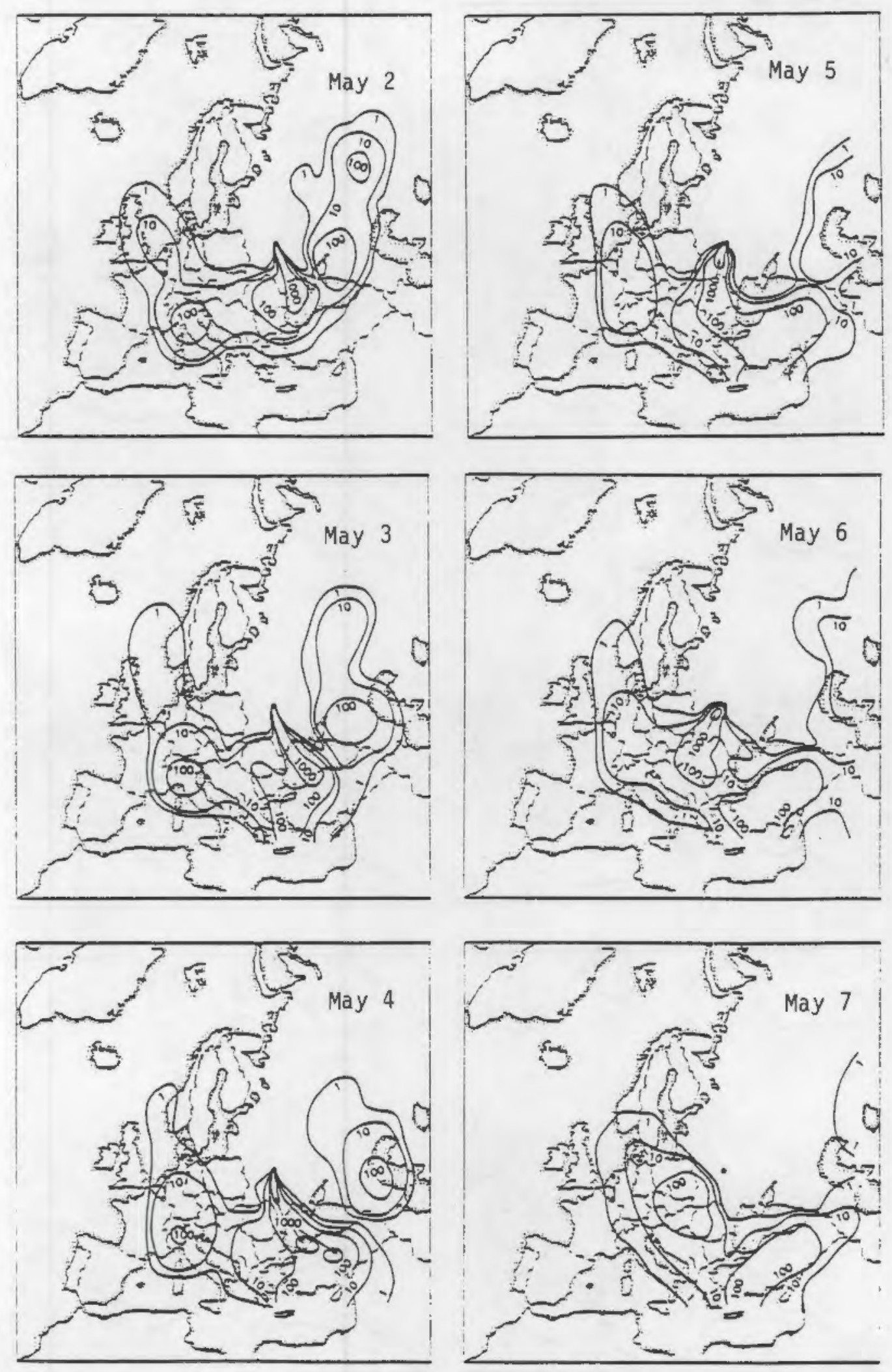

FIGURE 7.1. (contd) 

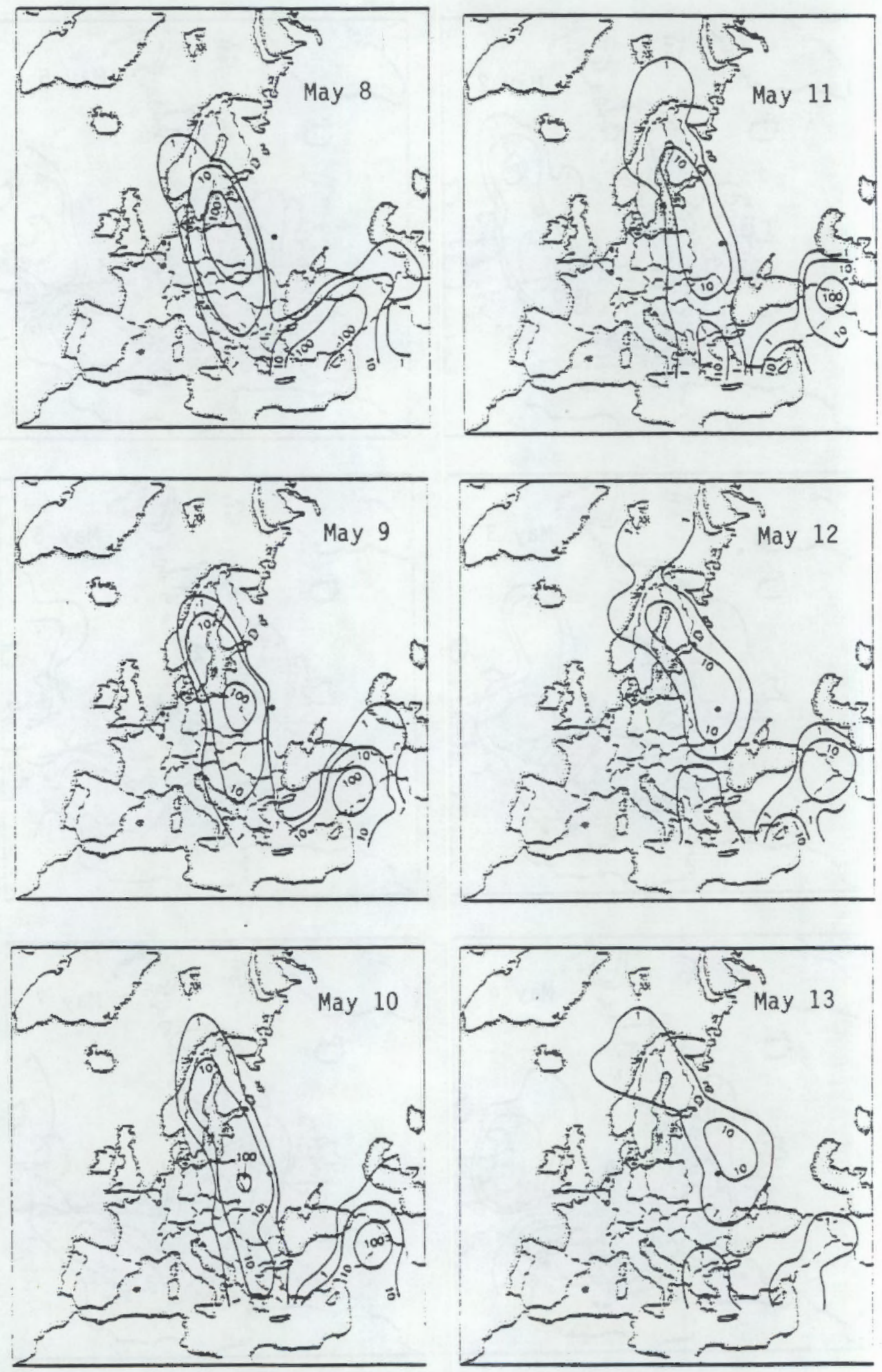

FIGURE 7.1. (contd) 

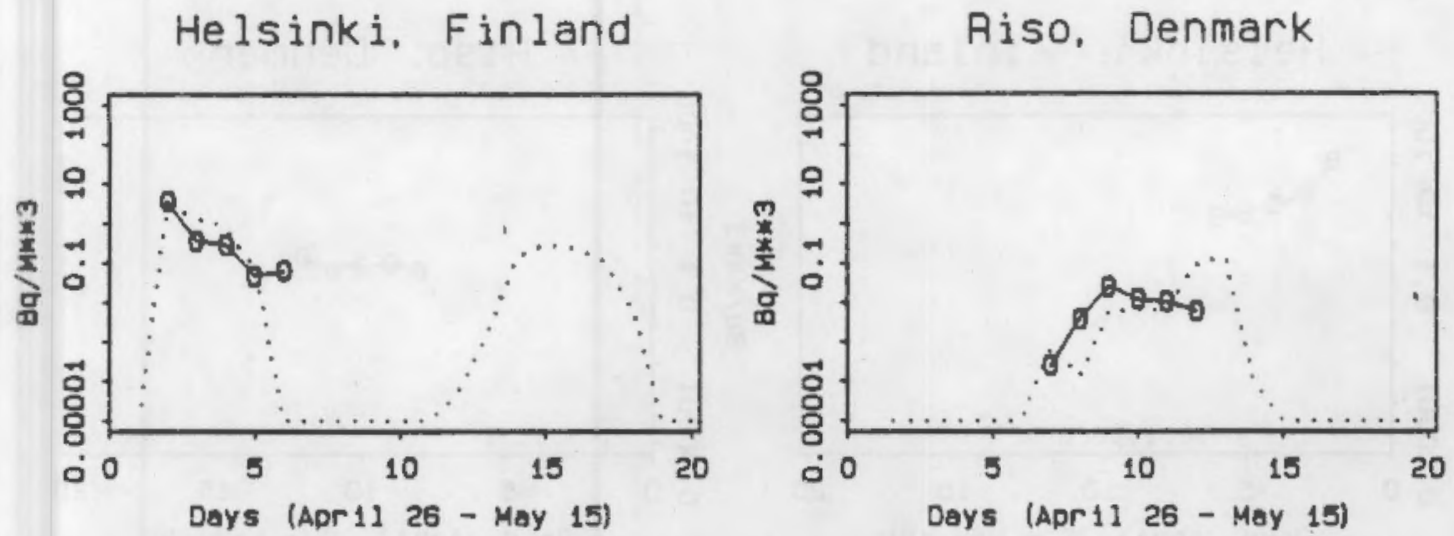

Bilthoven. Netherlands
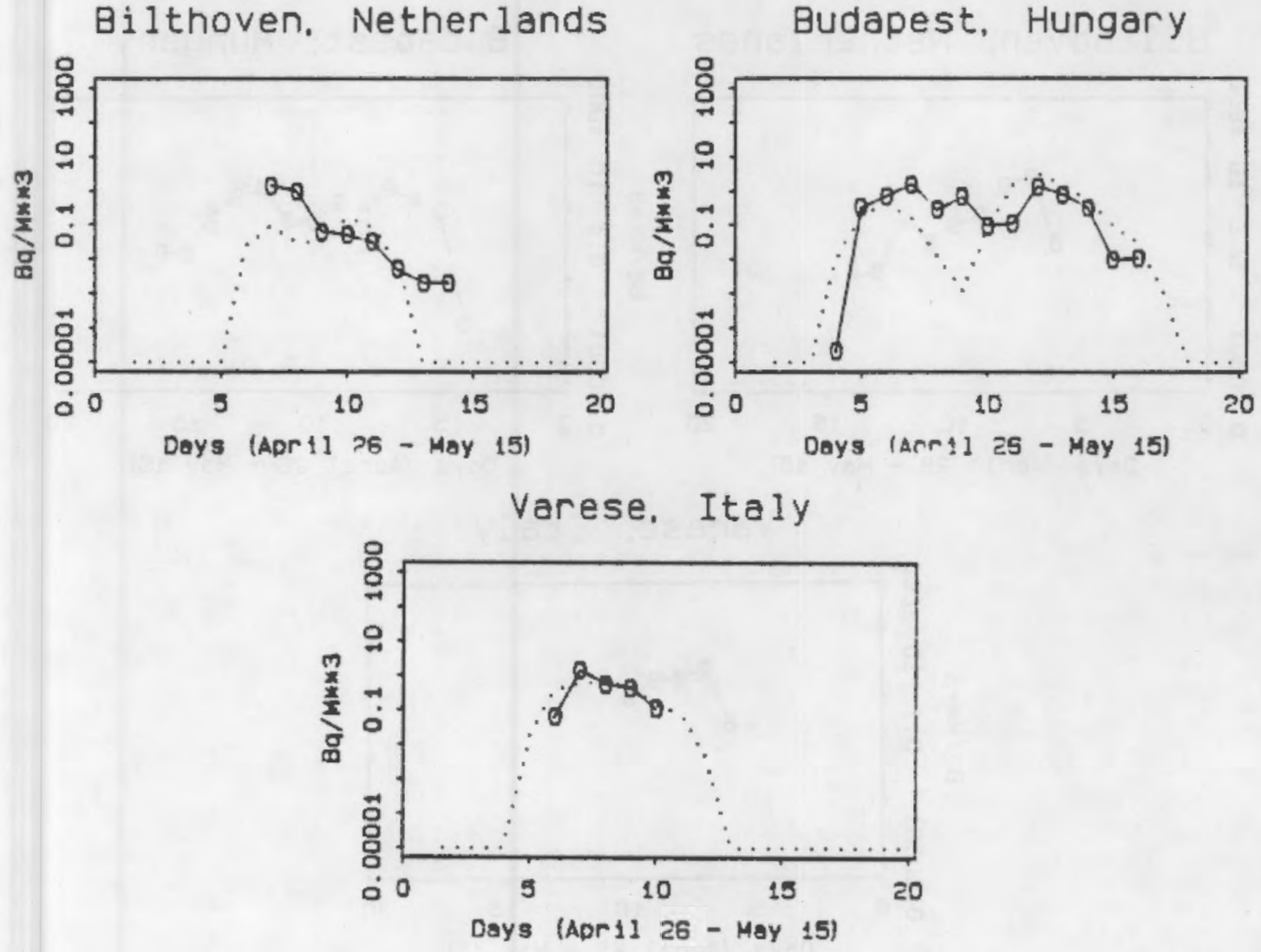

FIGURE 7.2. Cesium-137 Daily Air Concentrations $\left(\mathrm{Bq} / \mathrm{m}^{3}\right)$ at Helsinki, Riso, Bilthoven, Budapest, and Varese. Measured air concentration denoted by 0 and solid line and modeled air concentrations by dotted line. 

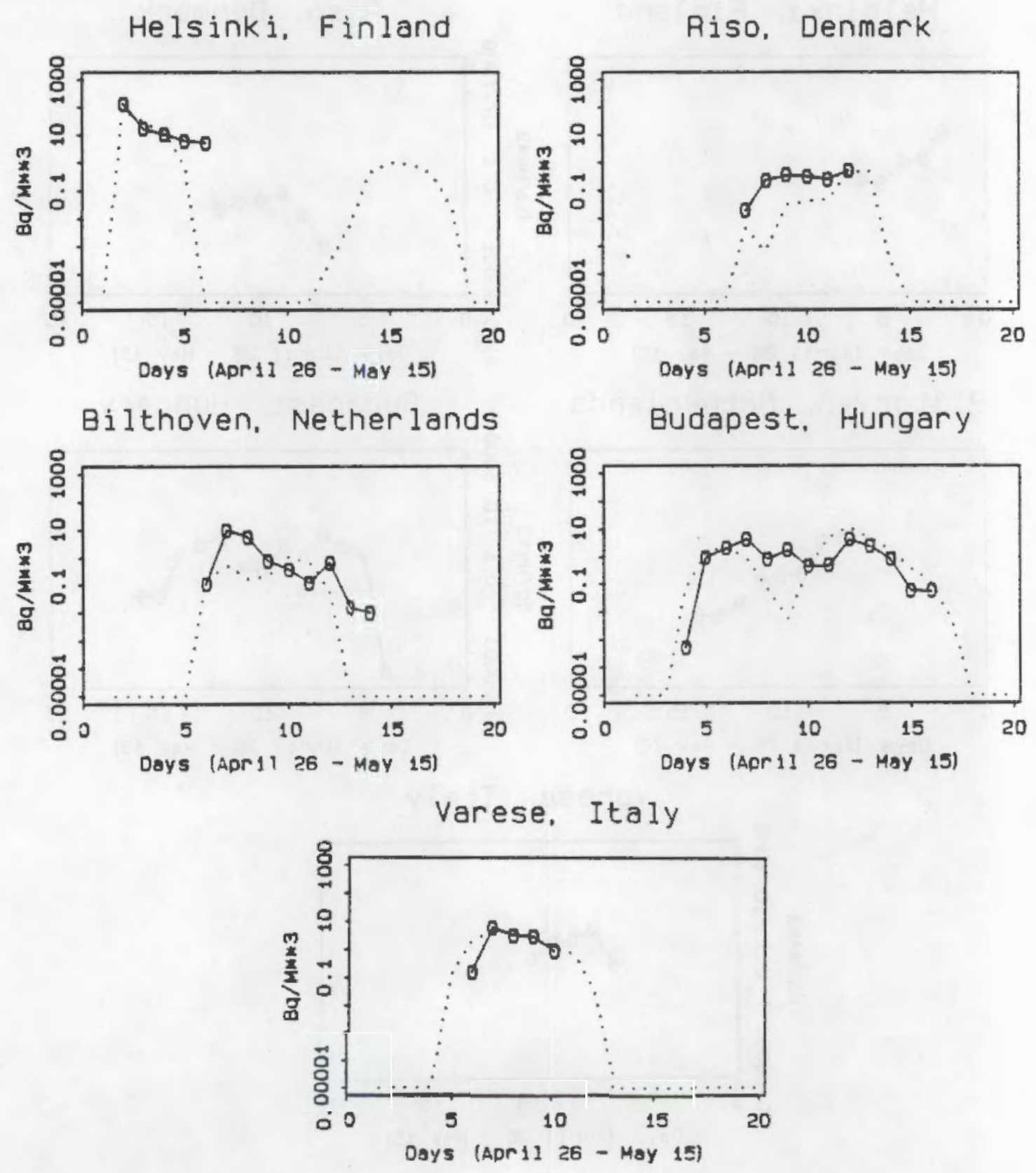

FIGURE 7.3. Iodine-131 Daily Air Concentrations $\left(\mathrm{Bq} / \mathrm{m}^{3}\right)$ at Helsinki, Riso, Bilthoven, Budapest, and Varese. Measured air concentration denoted by 0 and solid line and modeled air concentrations by dotted line. 
TABLE 7.1. Comparison of Measured and Modeled Air Concentrations $\left(\mathrm{Bq} / \mathrm{m}^{2}\right)$

\begin{tabular}{|c|c|c|c|c|c|}
\hline & Date & Iodi & 131 & $\mathrm{Ces}$ & -137 \\
\hline Location & Modeled & Modeled & Measured & Modeled & Measured \\
\hline Helsinki(a) & $\begin{array}{l}4 / 27 \\
4 / 28 \\
4 / 29 \\
4 / 30 \\
5 / 1\end{array}$ & $\begin{array}{c}8.7 \mathrm{E}+1 \\
3.2 \mathrm{E}+1 \\
1.4 \mathrm{E}+1 \\
6.9 \mathrm{E}-1 \\
--\end{array}$ & $\begin{array}{ll}1.4 & E+2 \\
1.7 & E+1 \\
1.1 & E+1 \\
6.3 & E+0 \\
5.2 & E+D\end{array}$ & $\begin{array}{cc}3.1 & E+0 \\
1.4 & E+0 \\
8.2 & E-1 \\
7.2 & E-2 \\
& =\end{array}$ & $\begin{array}{ll}3.7 & \mathrm{E}+0 \\
3.7 & \mathrm{E}-1 \\
3.0 & \mathrm{E}-1 \\
4.8 & \mathrm{E}-2 \\
6.3 & \mathrm{E}-2\end{array}$ \\
\hline Stockholm(b) & $\begin{array}{l}4 / 27 \\
4 / 28 \\
4 / 29 \\
4 / 30 \\
5 / 1\end{array}$ & $\begin{array}{cc}2.7 & \mathrm{E}+0 \\
4.2 & \mathrm{E}+0 \\
5.6 & \mathrm{E}-1 \\
1.5 \mathrm{E}-3 \\
--\end{array}$ & $\begin{array}{ll}6.2 & \mathrm{E}-1 \\
7.8 & \mathrm{E}+0 \\
3.1 & \mathrm{E}+0 \\
1.9 & \mathrm{E}+0 \\
9.6 & \mathrm{E}-2\end{array}$ & $\begin{array}{c}1.8 \mathrm{E}+0 \\
4.3 \mathrm{E}-1 \\
7.3 \mathrm{E}-2 \\
-- \\
--\end{array}$ & $\begin{array}{l}1.2 \mathrm{E}+0 \\
6.3 \mathrm{E}-1 \\
8.5 \mathrm{E}-1 \\
5.6 \mathrm{E}-1\end{array}$ \\
\hline Riso(c) & $\begin{array}{l}5 / 2 \\
5 / 3 \\
5 / 4 \\
5 / 5 \\
5 / 6 \\
5 / 7 \\
5 / 8 \\
5 / 9\end{array}$ & $\begin{array}{cc}4.3 & \mathrm{E}-3 \\
3.2 & \mathrm{E}-2 \\
4.5 & \mathrm{E}-2 \\
4.9 & \mathrm{E}-2 \\
4.0 & \mathrm{E}-1 \\
5.1 \mathrm{E}-1 & \end{array}$ & $\begin{array}{cc}1.9 & \mathrm{E}-2 \\
2.4 & \mathrm{E}-1 \\
3.7 & \mathrm{E}-1 \\
3.2 & \mathrm{E}-1 \\
2.6 & \mathrm{E}-1 \\
5.2 & \mathrm{E}-1 \\
-- & \\
--\end{array}$ & $\begin{array}{c}-- \\
6.1 \mathrm{E}-3 \\
6.8 \mathrm{E}-3 \\
6.3 \mathrm{E}-3 \\
9.0 \mathrm{E}-2 \\
1.4 \mathrm{E}-1 \\
--\end{array}$ & $\begin{array}{cc}2.4 & E-4 \\
3.7 & \text { E-3 } \\
2.5 & \text { E-2 } \\
1.2 & \text { E-2 } \\
1.0 & \text { E-2 } \\
6.0 & \text { E-3 } \\
-- & - \\
--\end{array}$ \\
\hline Bilthoven & $\begin{array}{l}5 / 1 \\
5 / 2 \\
5 / 3 \\
5 / 4 \\
5 / 5 \\
5 / 6 \\
5 / 7 \\
5 / 8 \\
5 / 9\end{array}$ & $\begin{array}{cc}1.5 & \mathrm{E}-1 \\
5.1 & \mathrm{E}-1 \\
1.6 & \mathrm{E}-1 \\
2.1 & \mathrm{E}-1 \\
1.1 & \mathrm{E}+0 \\
7.2 & \mathrm{E}-1 \\
6.5 & \mathrm{E}-2 \\
-- & \\
--\end{array}$ & $\begin{array}{ll}1.1 & \mathrm{E}-1 \\
9.6 & \mathrm{E}+0 \\
5.6 & \mathrm{E}+0 \\
7.4 & \mathrm{E}-1 \\
3.7 & \mathrm{E}-1 \\
1.2 & \mathrm{E}-1 \\
6.3 & \mathrm{E}-1 \\
1.6 & \mathrm{E}-2 \\
1.1 & \mathrm{E}-2\end{array}$ & $\begin{array}{cc}2.5 & \mathrm{E}-2 \\
9.2 & \mathrm{E}-2 \\
3.1 & \mathrm{E}-2 \\
3.5 & \mathrm{E}-2 \\
1.7 & \mathrm{E}-1 \\
9.1 & \mathrm{E}-2 \\
7.9 & \mathrm{E}-3 \\
-- & \\
--\end{array}$ & $\begin{array}{ll}1.4 & -\bar{E}+0 \\
9.3 & \mathrm{E}-1 \\
6.3 & \mathrm{E}-2 \\
5.2 & \mathrm{E}-2 \\
3.2 & \mathrm{E}-2 \\
5.2 & \mathrm{E}-3 \\
2.1 & \mathrm{E}-3 \\
2.1 & \mathrm{E}-3\end{array}$ \\
\hline Budapest (d) & $\begin{array}{l}4 / 29 \\
4 / 30 \\
5 / 1 \\
5 / 2 \\
5 / 3 \\
5 / 4 \\
5 / 5 \\
5 / 6 \\
5 / 7 \\
5 / 8 \\
5 / 9 \\
5 / 10 \\
5 / 11\end{array}$ & $\begin{array}{ll}7.4 & \mathrm{E}-2 \\
1.4 & \mathrm{E}+0 \\
2.1 & \mathrm{E}+0 \\
8.6 & \mathrm{E}-1 \\
6.9 & \mathrm{E}-2 \\
5.9 & \mathrm{E}-3 \\
3.8 & \mathrm{E}-1 \\
5.3 & \mathrm{E}+0 \\
1.1 & \mathrm{E}+1 \\
4.5 & \mathrm{E}+0 \\
1.7 & \mathrm{E}+0 \\
3.6 & \mathrm{E}-1 \\
1.2 & \mathrm{E}-1\end{array}$ & $\begin{array}{ll}5.4 & \mathrm{E}-4 \\
9.6 & \mathrm{E}-1 \\
2.0 & \mathrm{E}+0 \\
4.4 & \mathrm{E}+0 \\
8.1 & \mathrm{E}-1 \\
1.7 & \mathrm{E}+0 \\
4.4 & \mathrm{E}-1 \\
4.8 & \mathrm{E}-1 \\
4.1 & \mathrm{E}+0 \\
2.4 & \mathrm{E}+0 \\
8.1 & \mathrm{E}-1 \\
5.9 & \mathrm{E}-2 \\
5.6 & \mathrm{E}-2\end{array}$ & $\begin{array}{ll}1.0 & \mathrm{E}-2 \\
2.2 & \mathrm{E}-1 \\
3.4 & \mathrm{E}-1 \\
1.6 & \mathrm{E}-1 \\
1.3 & \mathrm{E}-2 \\
1.2 & \mathrm{E}-3 \\
8.2 & \mathrm{E}-2 \\
1.4 & \mathrm{E}+0 \\
3.3 & \mathrm{E}+0 \\
1.4 & \mathrm{E}+0 \\
5.4 & \mathrm{E}-1 \\
9.7 & \mathrm{E}-2 \\
3.1 & \mathrm{E}-2\end{array}$ & $\begin{array}{ll}2.1 & \mathrm{E}-5 \\
3.2 & \mathrm{E}-1 \\
7.0 & \mathrm{E}-1 \\
1.5 & \mathrm{E}+0 \\
2.8 & \mathrm{E}-1 \\
6.7 & \mathrm{E}-1 \\
9.6 & \mathrm{E}-2 \\
1.1 & \mathrm{E}-1 \\
1.3 & \mathrm{E}+0 \\
7.4 & \mathrm{E}-1 \\
3.1 & \mathrm{E}-1 \\
9.6 & \mathrm{E}-3 \\
1.1 & \mathrm{E}-2\end{array}$ \\
\hline
\end{tabular}


TABLE 7.1. (contd)

\begin{tabular}{|c|c|c|c|c|c|}
\hline \multirow[b]{2}{*}{ Location } & \multirow{2}{*}{$\begin{array}{l}\text { Date } \\
\text { Modeled }\end{array}$} & \multicolumn{2}{|c|}{ Iodine-131 } & \multicolumn{2}{|c|}{ Cesium-137 } \\
\hline & & Modeled & Measured & Modeled & Measured \\
\hline Varese & $\begin{array}{l}4 / 30 \\
5 / 1 \\
5 / 2 \\
5 / 3 \\
5 / 4 \\
5 / 5 \\
5 / 6 \\
5 / 7 \\
5 / 8 \\
5 / 9\end{array}$ & $\begin{array}{c}1.1 \mathrm{E}-1 \\
2.3 \mathrm{E}+0 \\
3.8 \mathrm{E}+0 \\
4.4 \mathrm{E}+0 \\
2.8 \mathrm{E}+0 \\
1.2 \mathrm{E}+0 \\
6.4 \mathrm{E}-1 \\
3.0 \mathrm{E}-2 \\
--\end{array}$ & $\begin{array}{c}1.6 \mathrm{E}-1 \\
6.3 \mathrm{E}+0 \\
3.3 \mathrm{E}+0 \\
2.9 \mathrm{E}+0 \\
9.3 \mathrm{E}-1 \\
-- \\
-- \\
--\end{array}$ & $\begin{array}{cc}1.7 & \mathrm{E}-2 \\
3.8 & \mathrm{E}-1 \\
6.2 & \mathrm{E}-1 \\
6.9 & \mathrm{E}-1 \\
4.1 & \mathrm{E}-1 \\
1.5 & \mathrm{E}-1 \\
7.4 & \mathrm{E}-2 \\
4.1 & \mathrm{E}-3 \\
-- & \end{array}$ & $\begin{array}{c}6.3 \bar{E}-2 \\
1.5 \mathrm{E}+0 \\
5.6 \mathrm{E}-1 \\
4.4 \mathrm{E}-1 \\
1.1 \mathrm{E}-1 \\
-- \\
-- \\
--\end{array}$ \\
\hline
\end{tabular}

No measurement data available denoted by dashed line.

(a) FCRNS, 1986.

(b) Staten Stralskydds Institute (SSI), 1986.

(c) National Agency of Environmental Protection, 1986.

(d) Andrasi et al., 1986.

Maximum estimated concentrations for a city are generally within a factor of two of the maximum measured concentration. Iodine-131 concentrations are underestimated by $30 \%$ (median) except for Budapest. For cesium-137, city maximums are either underestimated or overestimated by a factor of two. With estimated and measured concentrations matched in time, iodine-131 is typically underestimated by $40 \%$ (median) and cesium-137 is underestimated by $30 \%$. That is, the median ratio of estimated to measured daily air concentration is 0.62 and 0.69 for iodine-131 and cesium-137, respectively. For iodine-131, 75\% of the ratios are lower than 1.46 and $25 \%$ are lower than 0.10 . Helsinki, Stockholm, Riso, and Bilthoven are typically underestimated by a factor of two or more. For cesium-137, 75\% of the ratios are lower than 2.63 and $25 \%$ are lower than 0.05 . The same cities are also underestimated by a factor of two or more for cesium-137. A difficulty in making comparisons of estimated and measured concentrations is that the measurements are averaged over time periods that are different from the estimated concentration periods. In some cases the averaging periods may differ by as many as $9 \mathrm{~h}$. 


\subsection{REFERENCES}

Andrasi, A., E. Beleznay, S. Deme, I. Feher, L. Koblinger, Gy. Lancsarics, E. Lang, M. Lorinc, Gy. Nagy, I. Nemeth, L. Sagi, P. P. Szaso, G. Tokai, and P. Sambori. 1986. Monitoring the Radiation Consequences Due to the Disaster at the Chernobyl Nuclear Facility from April 28 to June 12, 1986, Preliminary Report. Hungarian Academy of Sciences, Central Research Institute for Physics, Budapest, Hungary.

ApSimon, H. M. and J. J. N. Wilson. 1986. "Tracking the Cloud from Chernobyl." New Scientist $111(1517): 42-45$.

Croff, A. G. 1980. ORIGIN2-A Revised and Updated Version of the Oak Ridge Isotope Generation and Depletion Code. ORNL-5621, Oak Ridge National Laboratory, Oak Ridge, Tennessee.

Davis, W. E. 1983. "Preliminary Results of an Eight-Layer Regional Assessment Model Applied to the Problem of Acid Rain." In Energy and Environmental Chemistry; Vol 2, Acid Rain, L. H. Keith, ed, pp. 287-299. Ann Arbor Science, Ann Arbor, Michigan.

Davis, H. E. and C. Glantz. 1986. "A Comparison of a Multilayer Regional Scale Acid Rain Assessment Model (MLRAPT) with a Single-Layer Assessment Model, RAPT." J. Water, Air and Soil Poll. 30:857-866.

Davis, W. E. and L. L. Wende11. 1976. "Some Effects of Isentropic Vertical Motion Simulation in a Regional Scale Quasi-Lagrangian Air Quality Model." In Proceedings of the Third Symposium on Atmospheric Turbulence, Diffusion and Air Quality. pp. 403-406, American Meteorological Society, Boston, Massachusetts.

Davis, W. E., A. R. Olsen, B. T. Didier, and D. W. Damschen. 1986. "A Comparison of Meso-Alpha MLAM Model Results with Observations from CAPTEX." In Proceedings of the Fifth Joint Conference on Applications of Air Pollution Meteorology. pp. 69-72, American Meteorological Society, Boston, Massachusetts.

Davis, W. E., A. R. 01sen, B. T. Didier, P. E. Tucker, and D. W. Damschen. 1989. Surface Footprint from Initial Chernobyl Release as Indicated by the Meso-Alpha MLAM Model. PNL-7186, Pacific Northwest Laboratory, Richland, Washington.

de Leeuw, F. A. A. M., R. M. van AAlst, and Han van Dop. 1987. "Modelling of Transport and Deposition Over Europe of Radionuclides from the Chernobyl Accident." In Preprint 16th International Technical Meeting on Air Pollution Modeling and Its Applications. April 6-10, 1987, Lindau, Federal Republic of Germany, Sponsored by Committee on Challenges of Modern Society, NATO.

DOE. 1987. Health and Environmental Consequences of the Chernobyl Nuclear Power Plant Accident. Report to the U.S. Department of Energy Office of Health and Environmental Research from the Interlaboratory Task Group on Health and Environmental Aspects of the Soviet Nuclear Accident, Washington, D.C. 
Draxler, R. R. and A. D. Taylor. 1982. "Horizontal Dispersion Parameters for Long-Range Transport Modeling." J. Appl. Meteor. 21:367-372.

Eimutis, E. C. and M. G. Konicek. 1972. "Derivations of Continuous Functions for the Lateral and Vertical Atmospheric Dispersion Coefficients." Atmos. Environ. 6:863-869.

FCRNS. 1986. Interim Report on Fallout Situation in Finland from April 26 to May 4, 1986. STUD-B-VALO 44, Finnish Centre for Radiation and Nuclear Safety, Finland.

Goldman, M., R. J. Caftin, L. Anspaugh, R. G. Cuddiky, W. E. Davis, J. I. Fabrickaut, A. Pittubb, R. Lange, D. Robertson, R. Schleuker, and E. Warman. 1987. Health and Environmental Consequences of the Chernobyl Nuclear Power Plant Accident. Report to the U.S. DOE Office of Health and Environmental Research, Washington, D.C.

Heffter, J. L. 1965. "The Variation of Horizontal Diffusion Parameters with Time for Travel Periods of One Hour or Longer." J. Appl. Meteor. 4:153-156.

Hoffman, M. S. (ed.). 1986. World Almanac and Book of Facts. Pharos Books, New York.

IAEA. 1986. Summary Report on the Post-Accident Review Meeting on the Chernobyl Accident. International Atomic Energy Agency, International Nuclear Safety Advisory Group' (INSAG), Vienna, Austria.

International Commission on Radiological Protection. 1959. Report of ICRP Committee II on Permissible Dose for Internal Radiation. ICRP Publication 2, Pergamon Press, New York.

Jenne, R. L. 1970. The NMC Octagonal Grid. National Center for Atmospheric Research, Boulder, Colorado.

Larson, K. H., J. V. Ramsdell, Jr., J. W. Sloot, D. J. Newland, W. E. Davis, and J. M. Nielsen. 1968. Project Cabriolet Research in Airborne Nuclear Cratering Debris in Support of Plowshare Technology. BNWL-836, Pacific Northwest Laboratory, Richland, Washington.

National Agency of Environmental Protection. 1986. The Reactor Accident at Chernobyl, USSR; Radioactivity Measurements in Denmark. Third Report; May 1986. Denmark.

Napier, B. A., W. E. Kennedy, Jr., and J. K. Soldat. 1980. PABLM - A Computer Program to Calculate Accumulated Radiation Doses from Radionuclides in the Environment. PNL-3209, Pacific Northwest Laboratory, Richland, Washington.

Ramsdell, J. V., J. M. Hubbe, G. F. Athey, and W. E. Davis. 1989. MESORAD Dose Assessment of the Chernobyl Reactor Accident. PNL-7185, Pacific Northwest Laboratory, Richland, Washington. 
Smith, F. B. 1987. "Chernobyl - The Radioactive Plume and Its Consequences." In Preprint 16th International Technical Meeting on Air Pollution Modeling and Its Applications. April 6-10, 1987, Lindau, Federal Republic of Germany, Sponsored by Committee on Challenges of Modern Society, NATO.

SSI. 1986. SSI-RAPPORT 86-12, Staten Stralskydds Institute, Stockholm, Sweden.

USSR State Committee on the Utilization of Atomic Energy. 1986. The Accident at the Chernobyl Nuclear Power Plant and its Consequences. Presented at the IAEA Experts' Meeting, August 25-29, 1986, Vienna, Austria. 



\section{DISTRIBUTION}

No. of

Copies

OFFSITE

2 DOE/Office of Scientific and Technical Information

ONSITE

DOE Richland Operations Office

E. C. Norman

19 Pacific Northwest Laboratory

W. E. Oavis

B. T. Didier

J. W. Falco

J. M. Hales

P. C. Hays

B. A. Napier

A. R. 0lson

E. L. Owczarski

R. A. Peloquin

R. L. Skaggs

J. K. Soldat

J. A. Stott lemyre

R. E. Wildung

Publishing Coordination

Technical Report Files (5) 
4

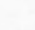

$n=$

.

$\therefore$ : 